\title{
Aluminum Alloy \\ Performance Under Dry Cooling Tower Conditions
}

by

A. B. Johnson, Jr.

S. Begej

M. W. Martini

R. P. May

December 1977

Prepared for the

U.S. Department of Energy

under Contract EY-76-C-06-1830 


\title{
NOTICE
}

This report was prepared as an account of work sponsored by the United States Covernment. Neither the United States nor the Department of Energy, not any of their employees, nor any of their contractors. subcontractors, or their employees, makes any warranty, express or implied, or assumes any legal liability or responsibility for the accuracy. completeness or usefuiness of any information, apparatus, product or process disclosed, or represents that its use would not infringe privately owned rights.

The views, opinions and conclusions contained in this report are those of the contractor and do not necessarily represent those of the United States Government or the United States Department of Energy.

\author{
PACIFIC NORTHWEST LABORATORY \\ operated by \\ BATTELLE \\ for the \\ UNITEO STAIES DEPARTMENT OF ENERCY \\ Under Contract EY-76-C-06-7830
}

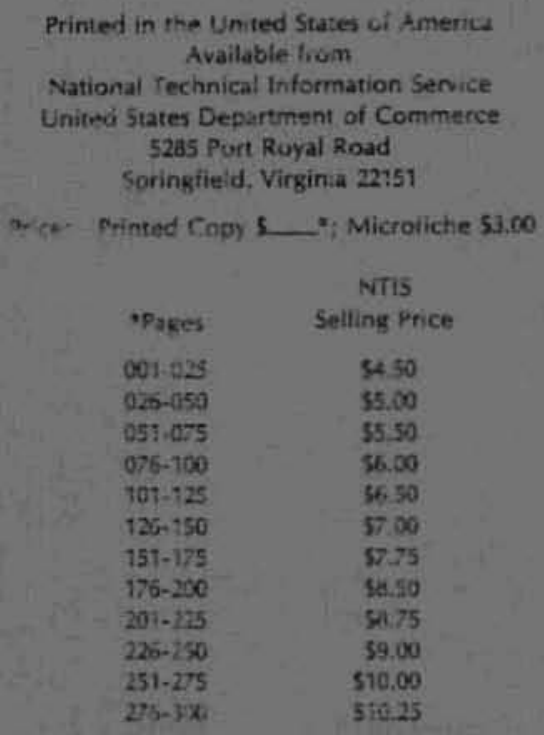


PNL-2392

UC -12

ALUMINUM ALLOY PERFORMANCE UNDER DRY COOLING TOWER CONDITIONS

by

A. B. Johnson, Jr.

S. Begej

M. W. Martini

R. P. May

December 1977

Battelle

Pacific Northwest Laboratories

Richland, Washington 99352 
FOREWORD

The Dry Cooling Tower Development Program at Battelle, Pacific Northwest Laboratories was initiated with a program scope that included the following near-term and ultimate emphases.

Near-Term Objectives:

- Develop economic and performance models for cost optimization of total heat rejection systems using dry cooling.

- Analyses of, and dissemination of experience on, existing dry-cooled plant performance.

- Demonstrate certain features of existing technology equipment to provide confidence for specification by utilities.

Ultimate Objective:

- Promote water conservation through industry use of dry cooling by developing and demonstrating the reliability of lower-cost systems. The development of advanced wet/dry systems is also considered to be within this scope.

Over the past two years the following documents have been issued, reporting the results of the work toward these objectives.

Cost Optimization of Dry-Cooled Heat Rejection Systems:

A Review and Assessment of Engineering Economic Studies of Dry-Cooled Electrical Generating Plants. B. C. Fryer, BNWL-1976, March 1976.

Heat Transfer and Pressure Drop Characteristics of Dry Tower Extended Surfaces. Part I: Heat Transfer and Pressure Drop Data. PFR Engineering Systems, Inc., PFR-7-100, March 1976.

Heat Transfer and Pressure Drop Characteristics of Dry Tower Extended Surfaces. Part II: Data Analysis and Correlation. PFR Engineering Systems, Inc., PFR 7-102, June 1976.

Analysis of Performance of Existing Dry-Cooled Plants:

Dry Cooling Tower Program: Results of Industrial Contacts Through August 1974. BNWL-1878, November 1, 1974. 
A Survey of Materials and Corrosion Performance in Dry Cooling Applications. A. B. Johnson, Jr., D. R. Pratt, and G. E. Zima, BNWL-1958, March 1976.

European Dry Cooling Tower Operating Experience. J. G. DeSteese and K. Simhan, BNWL-1995, March 1976.

Mathematical and Experimental Investigations on Dispersion and Recirculation of Plumes from Dry Cooling Towers at Wyodak Power Plarit in Wyoming. Y. Onishi and D. S. Trent, BNWL-1982,

February 1976.

Aluminum Alloy Performance under Dry Cooling Tower Conditions, A. B. Johnson, Jr., S. Begej, M. W. Martini, and R. P. May, PNL-2292, December 1977.*

Advanced Dry (wet/dry) Cooled Systems:

Preliminary Evaluation of Wet/Dry Cooling Concepts for Power Plants. W. V. Loscutoff, BNWL-1969, July 1976.

Compatibility of Ammonia with Candidate Dry Cooling System Materials. D. R. Pratt, BNWL-1992, Apri1 1976.

Scale Formation in Deluged Dry Cooling Systems. D. R. Pratt, BNWL-2060, March 1976.

Ammonia As An Intermediate Heat Exchange Fluid for Dry Cooled Towers. R. T. Allemann, B. M. Johnson, and G. C. Smith, BNWL-SA-5997, September 1976.

A group of recently issued reports serves the dual purpose of developing cost optimization models for dry cooling systems based on availatile technology and comparing the results of analyzing the costs of these systems with the projected cost of several advanced dry and wet/dry systems. Included in this group are:

An Engineering and Cost Comparison of Three Different All-Dry Cooling Systems. B. C. Fryer, D. W. Faletti, Dan J. Braun, David J. Braun, and L. E. Wiles, BNWL-2121, September 1976.

A Study of the Comparative Costs of Five Wet/Dry Cooling Tower Concepts. F. R. Zaloudek, R. T. Allemann, D. W. Faletti, B. M. Johnson, H. L. Parry, G. C. Smith, R. D. Tokarz, and R. A. Walter, BNWL-2122, September 1976.

${ }^{\star}$ This report. 
Dry Cooling of Power Generating Stations: A Summary of the Economic Evaluation of Several Advanced Concepts Via A Design Optimization Study and A Conceptual Design and Cost Estimate. B. M. Johnson, R. T. ATlemann, D.W. Faletti, B. C. Fryer, and F. R. Zaloudek, BNWL-2120, September 1976.

Costs and Cost Algorithms for Dry Cooling Tower Systems. P. A. Ard, C. H. Henager, D. R. Pratt, and L. E. Wiles, BNWL-2123, September 1976.

A User's Manual for the BNW-I Optimization Code for Dry-Cooled Power Plants. David J. Braun, Dan J. Braun, Warren V. Demier, D. W. Faletti, and L. E. Wiles, BNWL-2180, January 1977.

A recent report considers the economic, legal, and water availability factors which will contribute to selection of dry and wet/dry cooling vis-a-vis other methods of cooling in the future and thus influence the projected market for these types of cooling systems in the next twenty years.

An Overview of Economic, Legal, and Water Availability Factors Affecting the Demand for Dry and Wet/Dry Cooling for Thermal Power Plants. Paul L. Hendrickson, BNWL-2268, June 1977. 


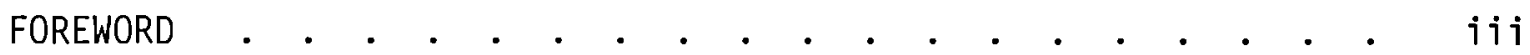

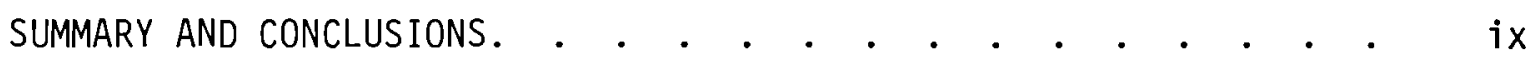

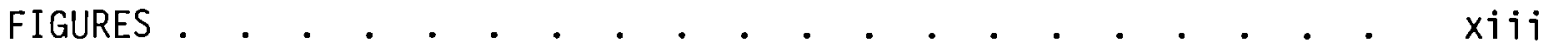

TABLES •

1.0 INTRODUCTION

2.0 SUMMARY OF PREVIOUS SURVEYS ON PERFORMANCE OF DRY-COOLED

PLANTS AND AIR-COOLED INDUSTRIAL EQUIPMENT. . . . . . . . . 3

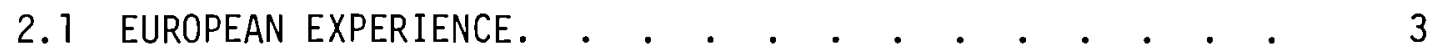

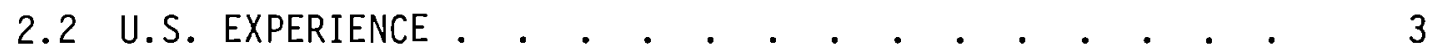

3.0 ATMOSPHERIC CORROSION OF ALUMINUM

4.0 EXPERIMENTAL - SPECIMEN EXAMINATIONS FROM OPERATING DRY-COOLED EQUIPMENT • • • • • • • • • • • • • • •

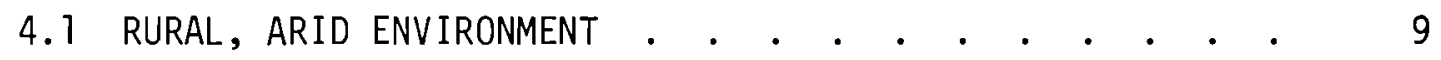

4.1.1 Wyodak, Wyoming . . . . . . . . . . . . . 9

4.1.2 Columbia Basin, Washington . . . . . . . . 9

4.2 RURAL, HUMID ENVIRONMENT . . . . . . . . . . . . . 10

4.2.1 Inland Gulf Coast Area, Mississippi . . . . . 10

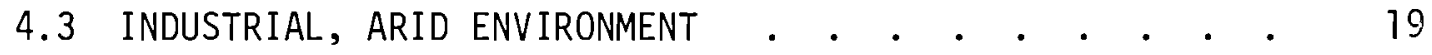

4.3.1 West Central Texas. . . . . . . . . . . 19

4.4 INDUSTRIAL, HUMID ENVIRONMENT • . • . • • . . . . . . 19

4.4.1 Ibbenbüren, Germany . . . . . . . . . . 19

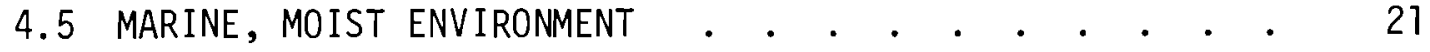

4.5.1 Southern California Coast . . . . . . . 21

4.6 MARINE, HUMID, INDUSTRIAL ENVIRONMENT. • • • • • • • 26

4.6.1 Gulf Coast Area of Louisiana . . . . . . . 26

4.6.2 Rugeley, England . . . . . . . . . . . 33 
5.0 LABORATORY EXPERIMENTS UNDER SIMULATED

DRY-COOLED AND AMBIENT CONDITIONS. . . . . . . . . . . . 41

5.1 EXPERIMENTAL . . . . . . . . . . . . . . . . . . 41

5.1.1 Materials . . . . . . . . . . . . . 41

5.1.2 Environment . . . . . . . . . . . . . 41

5.1.3 Examination Results . . . . . . . . . . 43

5.2 CONCLUSIONS-LABORATORY EXPERIMENT . . . . . . . . . 54

REFERENCES . . . . . . . . . . . . . . . . . . . 57

ACKNOWLEDGMENT . . . . . . . . . . . . . . . . . . 59

DISTRIBUTION . . . . . . . . . . . . . . . . . . Distr-1 


\section{SUMMARY AND CONCLUSIONS}

Aluminum alloys are important construction materials in air-cooled equipment. They have performed satisfactorily as fin materials in thousands of industrial air coolers. They also are utilized in several relatively large dry cooling towers for electrical generating stations, particularly in Europe. The prospects that additional dry-cooled power stations will be built in the U.S. over the next 20 years justifies development of a sound basis for material and site selection. Funding limits restricted this study to aluminum alloys, but other candidates also need a comprehensive assessment. In particular, the corrosion characteristics of galvanized steel, compared to aluminum alloys, are currently unknown. No conclusions can be drawn regarding the comparative merits of these two principal materials until a similar field survey and laboratory investigation are made of galvanized steel finned atmospheric heat exchangers.

The report draws on the following sources to define the scope of successful aluminum alloy performance and also to define problems which have developed:

- recent surveys of dry-cooled equipment performance in Europe ${ }^{(1)}$ and the U.S.; ${ }^{(2)}$

- metallographic examination of aluminum fin specimens from several operating plants with dry-cooled equipment, sited in a variety of environments;

- metallographic examination of aluminum alloy 6063 finned-tube specimens placed at two Gulf Coast locations, including specimens exposed both at ambient and cooling tower temperatures.

- metallographic examination of aluminum alloy 1100 specimens subjected to selected contaminants in a laboratory study, including specimens exposed both at ambient and at dry cooling tower temperatures.

The results of the investigations are summarized below: 
1. Aluminum alloys have performed satisfactorily in thousands of industrial air coolers, in exposures up to 28 years, principally at rural locations. Several aluminum-finned dry cooling towers in electrical generating plants also appear to be functioning well.

2. At a very small fraction of the sites, substantial corrosion of aluminum fins has occurred. Environments containing chlorides appear to be the most prevalent and consistent cause of corrosion on aluminum equipment. However, there is presently an incomplete basis for assessing the action of other contaminants.

3. Aluminum alloy finned-tube specimens were placed at two liulf Coast industrial sites which use air-cooled equipment. Samples were cut from the specimens at the end of 1-year and 2-year exposures.

a. After one and two years, very little corrosion had occurred on heated $\left(130^{\circ} \mathrm{F}, 56^{\circ} \mathrm{C}\right)$ specimens located at a rural location, approximately 6 miles $(9.2 \mathrm{~km})$ from the Gulf of Mexico. Ambient-temperature specimens mounted at a location away from the cooler were essentially free of corrosion; ambient-temperature specimens mounted under the cooler and subject to soap-laden spray during cooler cleaning operations showed substantial corrosion after two years. The effect of the soap is uncertain.

b. After one and two years at a location approximately 450 ft (137 meters) from the Gulf shore, aluminum alloy specimens exposed at approximately $120^{\circ} \mathrm{F}\left(50^{\circ} \mathrm{C}\right)$ had only minor evidence of corrosion attack. However, three specimens exposed only at ambient temperatures all showed advanced stages of corrosion. At the same location, failure of aluminum dry-cooled equipment occurred after 13 years. In addition to salt water, elemental sulfur was a potential contaminant, but its importance to the corrosion mechanism is not clear. 
4. Investigation of a section from a European aluminum-finned cooling tower indicated that at locations where coal dust was caked onto the fins, severe corrosion of the aluminum had been initiated. Very little corrosion was evident on the fins where coal dust was absent. The tower had been on line approximately 8 years. Analysis of coal dust removed from the fins indicated a chloride concentration of approximately 1500 wt ppm. Both sulfur and chloride contaminants were identified in the corrosion products.

5. Laboratory studies on aluminum alloy 1100 specimens indicated that sodium chloride was consistently an aggressive agent; elemental sulfur or $\mathrm{Na}_{2} \mathrm{SO}_{3}$ alone did not cause observable corrosion, but combinations of sulfur and chloride showed some evidence of a synergistic enhancement of corrosion; however, the evidence is based on only one laboratory observation. European coal (1500 wt ppm $\mathrm{Cl}^{-}$) and U.S. coal (28 wt ppm Cl${ }^{-}$) both initiated corrosion, but the attack caused by the European coal was notably more severe.

Laboratory specimens exposed perpetually at approximately $60^{\circ} \mathrm{C}$ generally had much less corrosion than specimens exposed perpetually at ambient conditions (approximately $20^{\circ} \mathrm{C}$ ). Specimens cycled between 20 and $60^{\circ} \mathrm{C}$ had corrosion more nearly characteristic of ambient-temperature specimens.

In summary, the principal conclusions from the study are:

- Aluminum alloys can be expected to have lifetimes of 30 years or more at dry cooling tower temperatures in "clean" environments. Many industrial air coolers with aluminum alloy fins also have had extended operation in contaminated environments.

- Effects of specific contaminants are not well defined at cooling tower temperatures, but chloride is clearly an aggressive agent on aluminum components, in agreement with extensive published evidence.

- Corrosion is most severe at temperatures below the dew point, where moisture can participate in the attack; severe corrosion seldom 
occurs at dry cooling tower temperatures, unless the plant is subject to considerable downtime; the implication is that high plant availabilities minimize corrosion; in aggressive environments, measures to minimize corrosion during extended outages may be desirable.

- The observation that caked coal dust promotes alumimum corrosion suggests that the relative siting of the cooling tower and the coal pile is an important consideration. The chloride content of the coal appears to be an important aspect of its corrosive character. Equally important may be the poultice effect of the coal contaminant. The particulate layer could trap impurities and might aid in establishing localized concentration cells.

- The importance of considering contaminants in material selection and siting of dry-cooled equipment is evident. For relatively smal1 units, where 15- to 20-year lifetimes may be acceptable, aggressive environments may be tolerable for aluminum alloys, particularly if plant downtime is likely to be minimal. For large dry cooling tower installations, protection of the relatively large capital investment in the tower opts for requisite attention to plant siting, material selection, and possible application of corrosion control measures during plant outages. At potential power plant sites where corrosion characteristics of candidate metals are not well-defined, corrosion evaluations should be made as part of the site evaluation.

- Laboratory studies at dry cooling tower and ambient temperatures caused corrosion similar to corrosion on some plant specimens. Placement of prototypic specimens on and near dry cooling tower equipment also appears to offer a useful approach to evaluate corrosion under dry cooling tower operating conditions.

- The cooling tower temperatures are similar to temperatures on some types of solar equipment. Therefore, the results of this study provide some insights to corrosion on aluminum components in solar equipment as a function of environment. 


\section{FIGURES}

1 Aluminum Fin After 18 Years of Exposure to a

Rura 1, Arid Environment.

2 Metallographic Cross-Section of Aluminum Alloy Fin

Shown in Figure 1 Indicating Minor Corrosion. . . . . . . 11

3 Aluminum Fin Removed from a Gas Pipeline Compressor Engine Cooler after Exposure to Rural, Humid Environment Near the Gulf Coast for 15 Years at about $130^{\circ} \mathrm{F}\left(\sim 54^{\circ} \mathrm{C}\right)$. . . . . . . . . . . . 12

4 Aluminum Fin Exposed to Rural, High Humidity Environment for 15 Years . . . . . . . . . . . . . . . .

5 Tube Specimen (Al Fins, Steel Tube) Similar to Specimens Installed at Two Gulf Coast Gas Compression Stations

6 Specimen Surface after Two Years of Exposure at Ambient Temperature in a Rural Humid Environment . . . . . . .

7 Aluminum Fin Exposed at Air Cooler Temperature $\left(130^{\circ} \mathrm{F}\right.$, $54^{\circ} \mathrm{C}$ ) for Two Years at a Rural-Humid Environment at a Gas Compressor Station in Mississippi, Near the Gulf Coast.

8 Aluminum Fin Exposed Only at Ambient Temperatures and Subjected Only to Rain Washing for Two Years at a Rural-Humid Environment

9 Aluminum Fin Exposed Only at Ambient Temperatures -

Subject to Spray from Cooler Cleaning Operations

During Exposure for Two Years to a Rural-Humid

Environment at a Gas Compressor Station in Mississippi

Near the Gulf Coast

10 SEM Micrographs and Microprobe Analys is of an Al Alloy 6063 Fin Specimen Exposed One Year in a Rural Humid Environment

11 Aluminum Fins Wrapped on Admiralty Tubing Exposed for 22 Years to a Low $\mathrm{SO}_{2}$, Low $\mathrm{S}$ Atmosphere

12 Oxide Thickness on Aluminum Fin Shown in Figure 11 is $0.05(1.3 \mu \mathrm{m})$ 


\section{FIGURES (Cont'd)}

13 Section of Dry Cooling Tower from Ibbenbüren, Germany . . .

14 Close-up of Coal Dust Fouling on Aluminum Plate-Type Fin .

15 Cooler Section Showing Alternate Layers of Al Plates and Spacers Stacked Around AT Tubes.

16 Metallographic Section through Tube, Spacer, and Fin Plate on Section of Aluminum Cooling Tower... . . . . . .

17 SEM Micrograph Showing Locations of Microprobe Analysis (Area B of Figure 16). . . . . . . . . . . . .

18 Close-up of Region C in Figure 16 Showing Severe Corrosion Under Coal Dust Deposit... . . . . . . . . . . 25

19 Scale Build-up on Inner Wall (Water-Side) of Tube. . . . . 25

20 Aluminum Alloy 1100 Fins Exposed for 20 Years in a Dry Marine Environment. . . . . . . . . . . . . . 27

21 Sub-Surface Corrosion, Concentrated Near the Tip of the Fin Shown in Figure 20 . . . . . . . . . . . . . 27

22 Aluminum Fins after Exposure for 13 Years to a Humid Marine Environment ( $\mathrm{CaCO}_{3}, \mathrm{Cl}$ and S Contaminant). . . . . 29

23 Metallographic Section Through a Tube from the Upper Bank, Refer to Figure 22 . . . . . . . . . . . .

24 Entargement of Region A in Figure 23 Showing Severe

Attack after 13-Year Exposure to a Humid Marine

Environment

25 An Etched View of a Fin in Figure 23 Showing Intergranular Nature of Corrosion . . . . . . . . . . 30

26 SEM Micrograph and Microprobe Analys is of an Aluminum Fin Exposed for 13 Years to a Humid Marine Environment . . . 31

27 Outer Edge of Fin Exposed for 9 Years to a Humid Marine Environment . . . . . . . . . . . . . . . . . 32

28 Micrographs Showing Opposite Sides (Left and Right of the Same Two Fins... . . . . . . . . . . 32

29 Aluminum Alloy 6063 Fins Exposed for 2 Years to a Humid Marine Industrial Environment 


\section{FIGURES (Cont'd)}

30 Aluminum Fin Placed in a Humid-Marine Environment Under an Atmospheric Cooler. . . . . . . . . . . . 34

31 Aluminum Alloy 6063 Fins Exposed for 2 Years to a Humid, Marine Industrial Environment . . . . . . . . . . 35

32 Aluminum Alloy 6063 Fins Exposed for 2 Years to a Humid, Marine Industrial Environment . . . . . . . . . . 36

33 SEM Micrograph and Microprobe Anaysis . . . . . . . . 37

34 Section of Cooler from Rugeley, England, Removed for Examination . . . . . . . . . . . . . . . . 39

35 Close-up of Crevice Locations where Pinhole Leaks were Reported to Have Initiated . . . . . . . . . . . 39

36 Aluminum Alloy 1100 Coupons Held at $60^{\circ} \mathrm{C}$ with (a) No Contaminants and (b) $\mathrm{NaCl}$ Contaminant after 405 Days . . . . . . . . . . . . . . .

37 Aluminum Alloy 1100 Coupons Contaminated with $\mathrm{NaCl}$ and (a) Held at $\sim 20^{\circ} \mathrm{C}$, (b) Periodically Cycled Between $\sim 20^{\circ} \mathrm{C}$ and $\sim 60^{\circ} \mathrm{C}$, after 405 Days . . . . . . . . .

38 Aluminum Alloy 1100 Coupons Held at $60^{\circ} \mathrm{C}$ and Contaminated with (a) Elemental Sulfur Only, and (b) Sulfur and $\mathrm{NaCl}$ after 405 Days . . . . . . . . . . . . . . .

39 Aluminum Alloy 1100 Coupons Contaminated with Elemental Sulfur and $\mathrm{NaCl}$ and (a) Held at $\sim 20^{\circ} \mathrm{C}$, (b) Periodically Cycled between $\sim 20^{\circ} \mathrm{C}$ and $\sim 60^{\circ} \mathrm{C}$ after 405 Days . . . .

40 Aluminum Alloy 1100 Coupons Held at $60^{\circ} \mathrm{C}$ and Contaminated with Coal from (a) Salinas, Utah (Low $\mathrm{Cl}^{-}$) (b) Ibbenbüren, Germany ( $\mathrm{High} \mathrm{Cl}^{-}$) after 405 Days. . . . . . . . .

41 Aluminum Alloy 1100 Coupons Cantaminated with $\mathrm{NaCl}$ and Coal from Ibbenbüren, fermany . . . . . . . . . .

42 Aluminum Alloy 1100 Coupons Contaminated with High $\mathrm{Cl}^{-}$Coal from Germany and a) Held at $\sim 20^{\circ} \mathrm{C}$ for 405 Days, b) Periodically Cycled between $\sim 20^{\circ} \mathrm{C}$ and $60^{\circ} \mathrm{C}$ for 405 Days 


\section{FIGURES (Cont'd)}

43 a) Unetched and b) Grain Boundary Etched View of an Aluminum Alloy 1100 Coupon Contaminated with $\mathrm{NaCl}$ and Coal from Ibbenburen, Germany and Periodically Cycled Between $\sim 20^{\circ} \mathrm{C}$ and $\sim 60^{\circ} \mathrm{C}$ after 405 Days.

44 Aluminum A1loy 1100 Coupon Contaminated with $\mathrm{S}+\mathrm{NaCl}$ and Held at $\sim 20^{\circ} \mathrm{C}$. . . . . . . . . . . . . . . . 52

45 Comparison of Corrosion Observed on Aluminum . . . . . . 53 


\section{TABLES}

1 Compressor Engine Dry Cooler Summary . . . . . . . . 5

2 Aluminum Alloys Used as Fin Materials for Dry-Cooled Heat Exchangers . . . . . . . . . . . . . . 6

3 Summary of Environments and Specimens Placed at a Gas Compressor Station in a Rural, Humid Gulf Coast Location . 13

4 Scope of Dry Cooling Tower Materials Investigation . . . 40

5 Environments, Contaminants and Relative Severity of Observed Corrosion on Aluminum Alloy 1100 . . . . . . . 42

6 Analysis of Salinas, Utah and Ibbenbüren, Germany, Coals . 54 


\section{.}

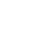

. 


\subsection{INTRODUCTION}

The large scale use of water for cooling purposes by central power stations is becoming increasingly problematic because of environmental restrictions, increasing water costs and increasing demand for water for other uses. These factors may make dry cooling an attractive option before the end of this century in some areas of the United States.

Battelle's Pacific Northwest Laboratories (PNL) is program manager for a Department of Energy (DOE), Division of Advanced Systems and Materials Production program to evaluate the feasibility of dry cooling utilization by the electric power generating industry. Corrosion was identified in an initial survey ${ }^{(4)}$ as a potentially costly factor which should be assessed in dry-cooled installations to minimize operating costs of future plants.

Previous reports $(1,2)$ have summarized materials performance in a crosssection of U.S. and foreign dry-cooled installations. This report supplements the previous reports with specific air-side corrosion data from operating dry-cooled installations and with corresponding laboratory studies. The report presents results of metallographic examinations on fin specimens taken from operating industrial air-cooled heat exchangers (dry coolers) and from dry cooling towers at power stations. The equipment operated in a variety of environments in the U.S. and Europe.

The previous surveys indicated that, in general, dry-cooled equipment operates with a minimum of operational problems. Therefore, it should be emphasized that the corrosion results reported here represent worst cases. For the most part, fin specimens were collected from coolers and towers that were known to have corrosion problems, though specimens from trouble-free plants also are shown. A major objective of this study has been to define environments which can be expected to cause corrosion; also to suggest possible causes of the corrosion. In general, corrosion has not been a frequent problem in dry-cooled equipment. Correct siting and materials selection will assure that corrosion problems are minimal in future installations. Aluminum is one of two predominant fin materials now used in dry-cooled power plants; the other principal material is galvanized steel. Both materials have performed 
satisfactorily for long periods with few exceptions. This report examines the exceptions for aluminum equipment, with the objective of defining environments which should be avoided. No attempt is made to compare the two materials as there is not at this time a similar study for galvanized steel. 


\subsection{SUMMARY OF PREVIOUS SURVEYS ON PERFORMANCE OF DRY-COOLED PLANTS AND AIR-COOLED INDUSTRIAL EQUIPMENT}

In a discussion of corrosion on dry-cooled equipment, it is important to provide a broad perspective, so the corrosion which is problematic at a few sites is not interpreted as a major industry-wide problem. The surveys cited earlier $(1,2)$ reflected successful dry-cooled equipment performance at the large majority of locations. Identification and characterization of sites which cause corrosion provide future selectors of plant sites for drycooled equipment with a basis for avoiding similar problems.

The following discussion briefly summarizes the results of the previous surveys.

\subsection{EUROPEAN EXPERIENCE}

The survey of European experience with dry-cooled electrical generating plants included reviews of five plants with aluminum fins and tubes and 13 plants with steel tubes and galvanized steel fins. (1) The corrosion performance of the plants was generally satisfactory. The cases where corrosion of aluminum components were a significant problem (Ibbenbüren and Rugeley) are discussed in some detail later in this report.

\subsection{U.S. EXPERIENCE}

The only aluminum-finned dry-cooling tower at a U.S. central generating station is a 3-MWe coal-fired unit at Wyodak, Wyoming. The unit began operation in 1962. Detailed examinations of aluminum components from Wyodak indicated that after $\sim 10$ years corrosion was not a problem. $(6,7)$ other small dry-cooled power plants were identified in the survey, providing electricity for remote industrial plants. Aluminum alloy finned tubes also have operated satisfactorily in such units.

A coal-fired dry cooling tower having galvanized steel fins began operations at Wyodak in 1969. We have not performed metallographic exams on the fins, but we did partitipate in an on-site inspection in 1975, which suggested that the fins were performing satisfactorily in the dry, rural, coa 1-plant environment. 
The survey of U.S. gas pipeline compressor engine coolers ${ }^{(2)}$ comprised responses from six pipeline companies, including some of the largest in the country, covering most of the geographic areas in the U.S., from California to Florida, and from Texas to New York and to the State of Washington. The coolers generally operate at 120 to $150^{\circ} \mathrm{F}\left(50\right.$ to $\left.70^{\circ} \mathrm{C}\right)$. The scope of the survey is summarized in Table 1. Of the 219 stations covered in the survey, only two have experienced severe corrosion problems. One station is located within a few yards of the Gulf of Mexico. Corrosion at this site is discussed later as a part of this study. The other site is located $\sim 30$ miles from the Gulf. The corrosion occurred in 21960 and details are not available.

Air-cooled equipment at some sites included in the survey has now exceeded thirty years of successful operation, generally at rural sites. At some industrial plants having highly corrosive environments, lifetimes of air-cooled equipment frequently are 15 years or less. However, with proper siting and operation, dry-cooled power stations should be able to avoid short tower lifetimes.

Materials in small industrial air coolers include fins fabricated from aluminurn alloys, copper alloys, galvanized mild steel and stainless steel. In some designs, the fins are wrapped onto or soldered to a tube which carries the stream to be cooled. A common combination in the pipeline coolers is aluminum fins wrapped onto Admiralty brass or copper-nickel tubes. At most locations, the combination has performed wel1. However, if conditions during outages permit moisture to accumulate in the aluminum/ copper crevice formed by the wrap-on design, severe corrosion can result in three to five years, due to galvanic corrosion of the aluminum by the copper alloy. The resulting build-up of corrosion products in the crevice inhibits heat flow. When necessary, the crevice can be eliminated by the use of extruded fins or sealed with a coating of some sort as was done at Rugeley. (2)

The generally favorable corrosion performance of dry-cooled equipment relies to a major extent on the fact that it operates above the dewpoint, minimizing the action of moisture. The importance of time-of-wetness as a parameter in atmospheric corrosion defines the benefit of dry operation. (2) Even in contaminated environments, corrosion at dry-cooling tower temperatures is much less than at ambient temperatures. Corrosion which occurs while the plant is not operating thus becomes a potentially important consideration. 
$\underline{T A B L E}$ 1. Compressor Engine Dry Cooler Summary ${ }^{(2)}$

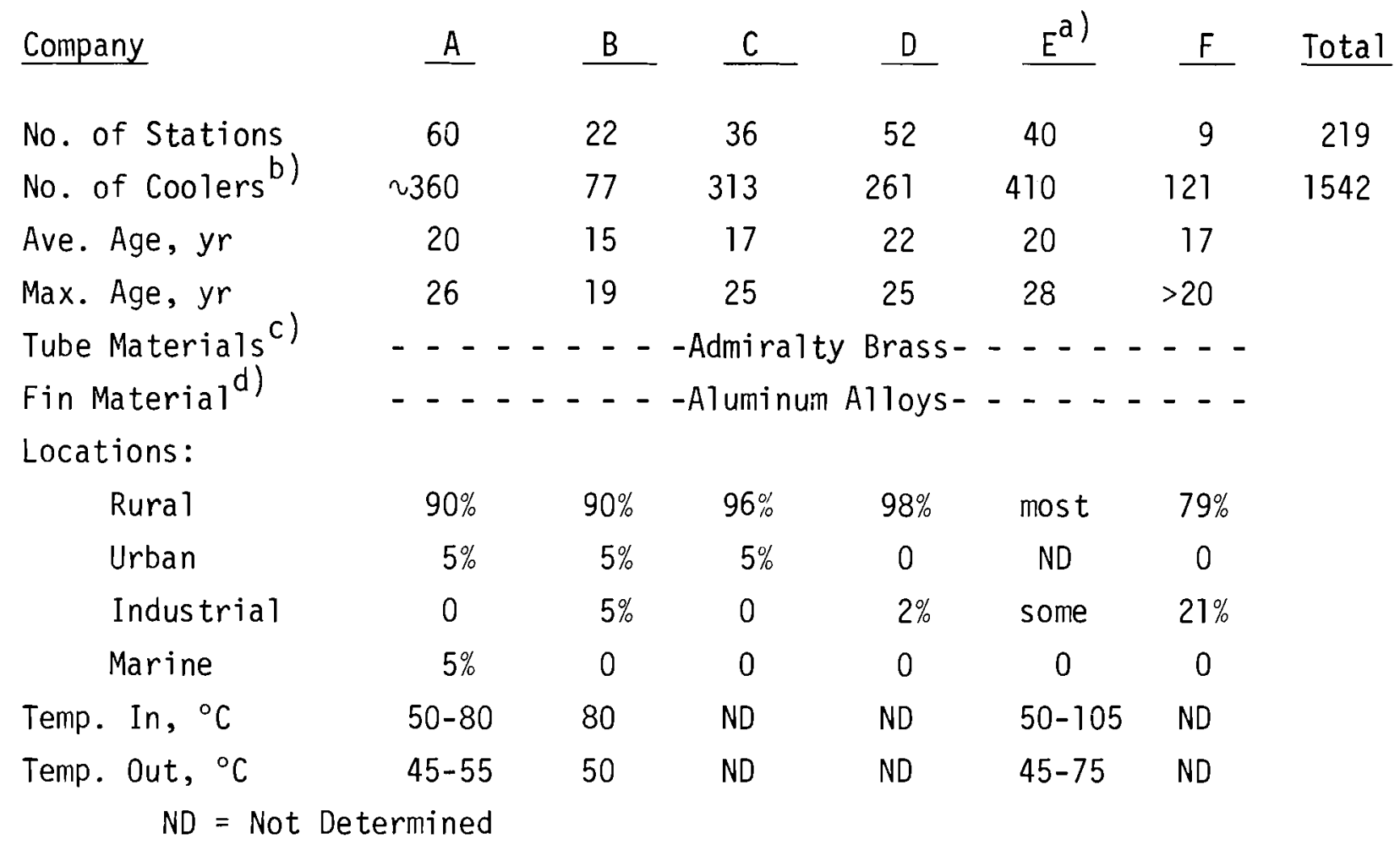

\footnotetext{
a) Company $\mathrm{E}$ also uses dry coolers in other applications, including steam condensing and process cooling; the total number of coolers in their system is 21000 .

b) As defined here, the number of coolers is approximately the same as the number of fans.

c) Some units use an extruded aluminum alloy fin/tube configuration having a carbon steel tube liner which serves as the conduit for the coolant.

d) A few pipeline coolers use copper fins.
} 


\subsection{ATMOSPHERIC CORROSION OF ALUMINUM}

The nominal compositions of the aluminum alloys most commonly used in dry-cooled equipment are given in Table 2. The alloys used most frequently are 6061, 6063 and 1100. Common finned tube designs included extruded, plate and tension wound. (5)

TABLE 2. Aluminum Alloys Used as Fin Materials for Dry-Cooled Heat Exchangers

Alloy Designation

1100

3003

5052

5454

6061

6063

7072

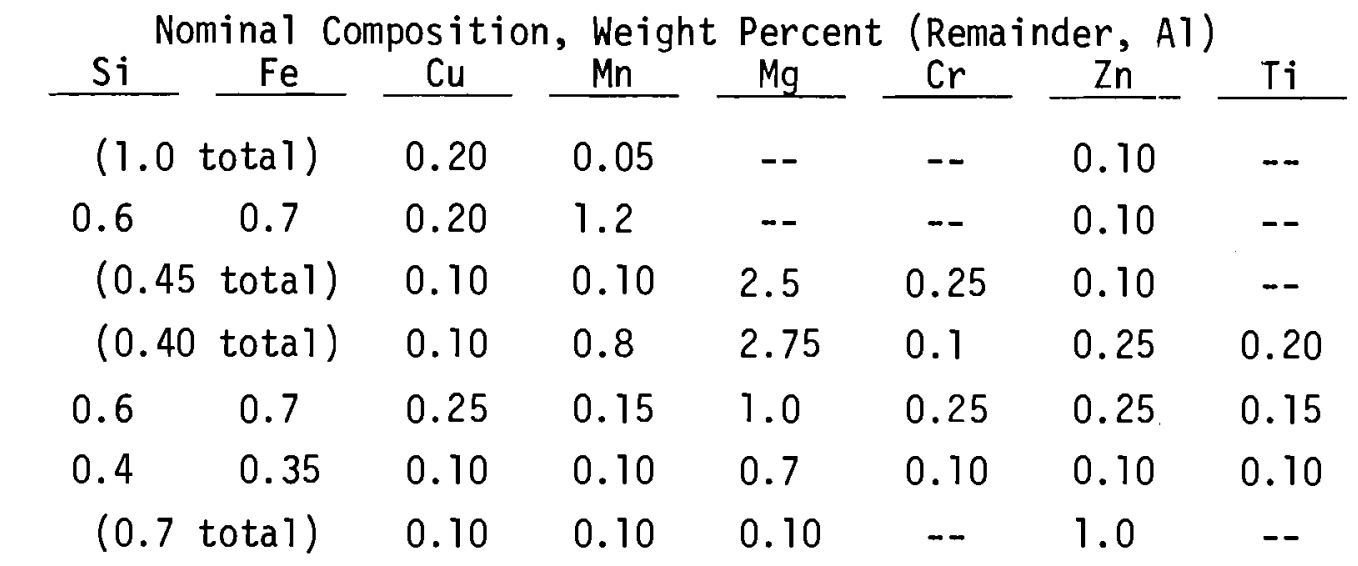

Alloy 7072 is sometimes used on selected alloys in atmospheric applications by cladding it onto an appropriate alloy substrate. This minimizes the substrate alloy perforation from pitting by limiting the depth of attack through the electrochemical protective action of the $\mathrm{Zn}$ in the 7072 alloy.

Atmospheric corrosion data at ambient temperatures are not an adequate basis for prediction of corrosion under dry-cooling tower conditions, for the reason indicated in the previous section. However, atmospheric corrosion data tend to represent worst-case conditions for dry-cooled equipment. Also, they are relevant to corrosion which occurs while the plant is off-line.

Atmospheric corrosion data for aluminum alloys, reported previously $(2,8,9)$ will be suminarized here. Atmospheric corrosion of aluminum under average rural conditions is minimal. At industrial sites, atmospheric corrosion of aluminum alloys varies substantially, depending on specific environments. At one industrial site, the greatest corrosion occurred during the first two years, followed by low subsequent corrosion rate. ${ }^{(8)}$ However, atmospheric 
corrosion of aluminum is sensitive to environmental conditions; air quality varies widely from one "industrial" area to another. Relatively high nearlinear corrosion rates of aluminum have been observed at some industrial sites. $(8,9)$

Marine industrial atmospheres tend to be the most corrosive to aluminum alloys. Marine atmospheres also may be corrosive to aluminum. The "marine" category includes a wide variation in local conditions (wind, salt deposition, periodic wetting, rain washing, etc.). Both marine and marine industrial atmospheres result in variations in aluminum corrosion which depend on local conditions. Conditions which cause acid chloride environments on aluminum surfaces are a significant factor in promoting intergranular attack on aluminum alloys at relatively low temperatures.

Atmospheric corrosion of aluminum alloys proceeds by attack at local anodic sites, developing a shallow, self-limiting oxide. The attack then develops at other anodic sites, gradually progressing over the entire surface and finally reaching a low steady-state rate. ${ }^{(2,9)}$ The low rate generally is reached after 2 to 3 years and continues unless the protective nature of the oxide is disturbed. Chloride ion is a common depassivator of aluminum, $(10)$ resulting in accelerated, often localized corrosion.

Preliminary data from aluminum fins collected from dry coolers at several locations in the U.S. indicated mild corrosion at most sites. (2) However, severe intergranular attack occurred on Alloy 1100 aluminum fins exposed at a marine site which also was subjected to elemental sulfur. However, our laboratory studies do not clearly implicate elemental sulfur as a corrosive agent. Alloys of the $6 \mathrm{XXX}$ series (Mg $+\mathrm{Si}$ alloys) are known to be susceptible to intergranular corrosion. Intergranular corrosion can be caused by the precipitation of $\mathrm{Mg}_{2} \mathrm{Si}$ along the grain boundaries, because this produces an anodic boundary that is more susceptible to corrosion. Alloys of the $2 x \times X$ are also susceptible to intergranular corrosion due to precipitation of $\mathrm{CuAl}_{2}$ at the grain boundaries during age hardening; $(8,11)$ however, aluminum alloys of the $2 \mathrm{XXX}$ series are not generally used as fin material. 
Intergranular corrosion has been produced experimentally in high-purity a luminum exposed to $4.7 \mathrm{~N} \mathrm{HCl}$ at room temperature ${ }^{(12)}$ or distilled water at $100-150^{\circ} \mathrm{C} .{ }^{(13)}$ Aluminum alloys (Al-Mg-Si and Al-CU) also corroded intergranularly under the influence of chloride ion. $(14,15)$ Under the conditions in our experiments, the chloride ion attack was transgranular but some intergranular attack occurred on industrial equipment where chloride was at least one participant in the attack. It has been postulated that if intergranular corrosion of pure aluminum is caused by stress in the grain boundaries, small amounts of impurity would tend to increase this stress factor and increase the susceptibility to intergranular attack.

The influence of sulfur contamination on intergranular corrosion is largely unknown; sulfur is generally noncorrosive to aluminum in the elemental state, as evidenced by its wide use in the sulfur mining industry and in the handling of molten sulfur. (16) Sulfur salts can be corrosive, and sulfuric acid will react with aluminum to form aluminum sulfate. (17) Atmospheric sulfur, in the form of $\mathrm{SO}_{2}$ and $\mathrm{SO}_{3}$ seems to have no effect on aluminum unless moisture is also available. ${ }^{(18,19)}$

Settled carbon particles, as in coal dust, will cathodically accelerate corrosion, but this effect is generally slight. ${ }^{(20)}$ Potentially more important is the action of the coal-dust layer in providing a poultice, which traps impurities and may contribute to localized concentration cells. 


\subsection{EXPERIMENTAL - SPECIMEN EXAMINATIONS FROM OPERATING DRY-COOLED EQUIPMENT}

Visits were made to several plants which use air-cooled heat exchangers (dry coolers) and operating dry-cooling towers sited in a variety of environments. Operating and historical data were collected, and, where possible, fin samples were taken for analysis. The results of this work are presented below, classified according to environment. Plant and company names are not identified in most cases for proprietary reasons.

\subsection{RURAL, ARID ENVIRONMENT}

4.1.1 Wyodak, Wyoming

The only operating dry-cooled central power plant in the U.S. is the Neil Simpson Station at Wyodak, Wyoming. This station consists of two units rated at 3 and 22 MWe that have been in service since 1962 and 1969, respectively. These are direct-cycle units; that is, the steam passes directly from the turbine to the dry cooling tower, where it condenses and returns to the boiler as condensate. The 3-MWe unit is cooled by a tower constructed by Griscom-Russe1; it consists of wrapped-on aluminum fins, Admiralty brass tubes and steel headers. The 22-MWe unit was constructed by GEA and consists of galvanized steel fins on carbon steel tubes. A 330 Mwe unit, now under construction at Wyodak will be the world's largest single operating unit.

No fin samples were obtained from Wyodak; the results given here are based on examination of Wyodak components reported by others, $(7,9)$ indicating that aluminum component performance at Wyodak has been satisfactory after more than 10 years of service.

\subsubsection{Columbia Basin, Washington}

A pipeline company operates a natural gas compressor station in an arid, rural environment near the Columbia River in southeastern Washington (see Fig. 2 of Ref. 2). The jacket water from the compressor engines of this station is cooled by several air-cooled heat exchangers that have been 
in service since 1956. The coolers consist of Admiralty brass tubes with solder-bonded aluminum fins. The inhibited glycol solutions from the compressor engines enter the coolers at about $175^{\circ} \mathrm{F}\left(79^{\circ} \mathrm{C}\right)$ and exits at about $120^{\circ} \mathrm{F}\left(49^{\circ} \mathrm{C}\right)$. No corrosion problems have occurred on these coolers in what is now 20 years of operation.

A fin specimen taken from the bottom row of tubes from one cooler is shown in Figure 1. About $70 \%$ of the fin area is covered by a thin layer of aluminum oxide; the darker areas toward the lower edge of the specimen are solder. No corrosion of the fin was associated with the solder. Maximum pit depth was about $0.3 \mathrm{mil}(7.6 \mu \mathrm{m})$ (Fig. 2). Extrapolation of these results suggests that expectation of 30 years or more of useful life at this location appears reasonable.

\subsection{RURAL, HUMID ENVIRONMENT}

\subsubsection{Inland Gulf Coast Area, Mississippi}

A compressor station similar to that described above operates in a rural, humid environment approximately 6 miles $(9.2 \mathrm{~km})$ from the Mississippi Gulf Coast. This station has seven coolers, which consist of aluminum fins wrapped on to Admiralty brass tubes. The coolers have operated for 17 years with no air-side corrosion problems. Fouling of the fins by pollerl, insects and dust occurs periodically. The fins are washed as needed with a detergent and with water or steam to remove this material (generally once per year).

Figure 3 shows a fin sample from the upper bank of tubes, which operate at about $130^{\circ} \mathrm{F}\left(54^{\circ} \mathrm{C}\right)$. The air cooler had been in service 215 years when samples were taken. The amount of time at ambient temperatures over the life of the cooler is not clear, but in recent years the cooler has been at an elevated temperature approximately $80 \%$ of the time.

Figure 4 is a metallographic section of the fin shown in Figure 3 . The aluminum oxide film thickness varies between $0.025 \mathrm{mil}$ and $0.12 \mathrm{mil}(0.64$ to $3 \mu \mathrm{m}$ ) between the base and rim of the fin. Pit depths ranged from 0.02 to $0.14 \mathrm{mils}(0.5$ to $3.6 \mu \mathrm{m})$. Successful performance of aluminum alloy dry coolers in this environment for $30+$ years appears to be a reasonable prospect. 


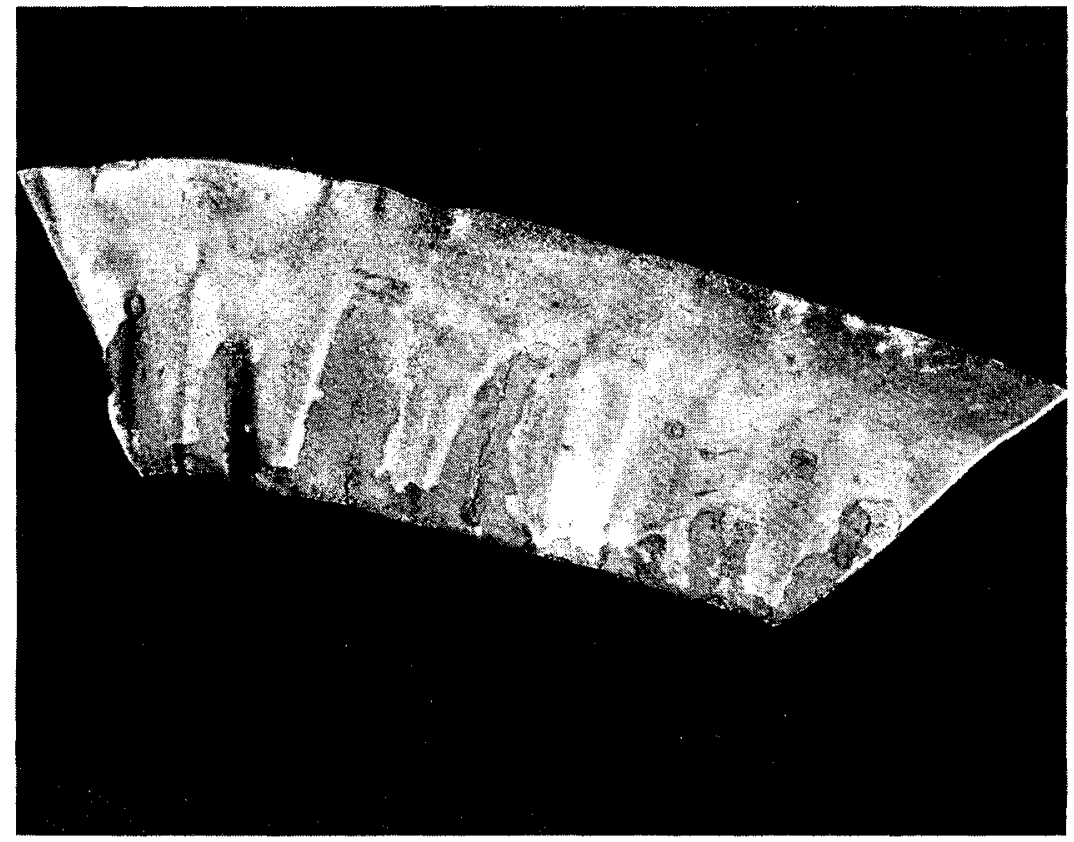

Neg. No.

4K207B

$2.2 X$

FIGURE 1. Aluminum Fin After 18 Years of Exposure to a Rura1, Arid Environment. Fin Was Bonded to Tube by Solder (Dark, FingerLike Areas Originating on Fin Lower Edge).

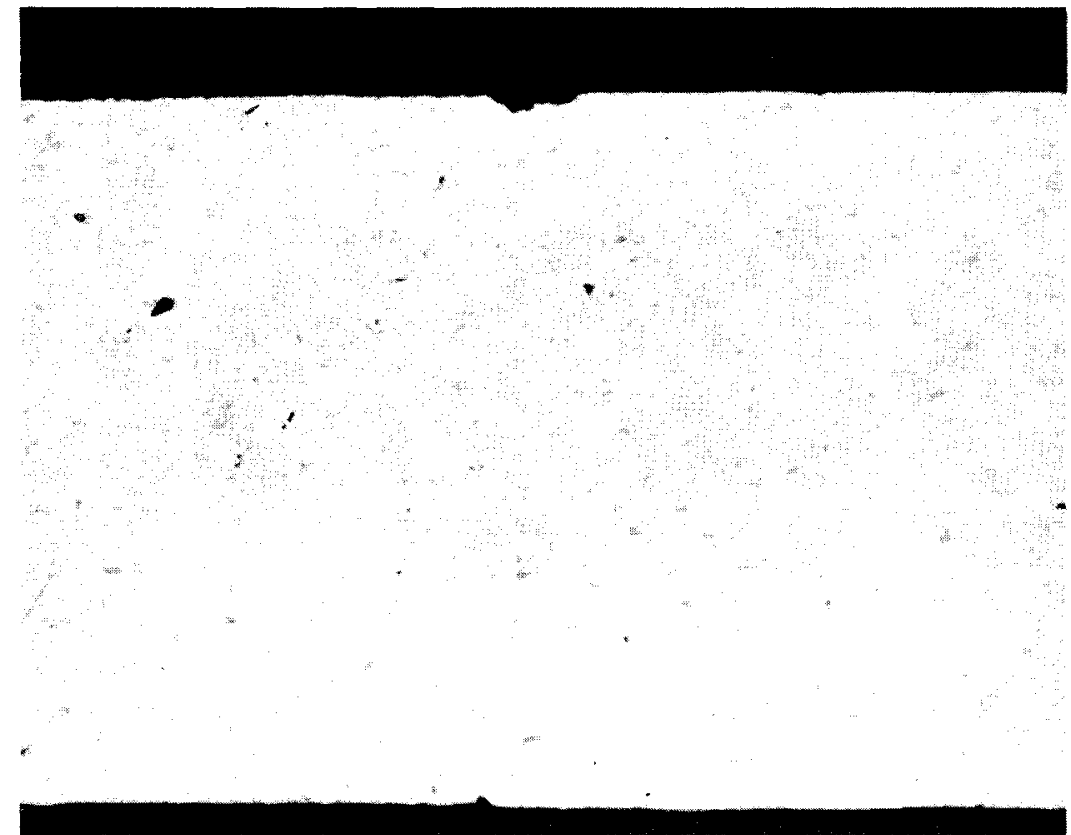

Neg. No. $4 \mathrm{~K} 207 \mathrm{~K}$

$300 x$

FIGURE 2. Metallographic Cross-Section of Aluminum Alloy Fin Shown in Figure 1 Indicating Minor Corrosion. Maximum Pit Depth is $0.3 \mathrm{Mi} 1$ ( $8 \mu \mathrm{m})$. 
Neg. No.

$3 \mathrm{~F}-1$

FIGURE 3. Aluminum Fin Removed from a Gas Pipeline Compressor Engine Cooler after Exposure to Rural, Humid Environment Near the Gulf Coast for 15 Years - at about $130^{\circ} \mathrm{F}\left(254^{\circ} \mathrm{C}\right)$. Surface Shows Little Corrosion.

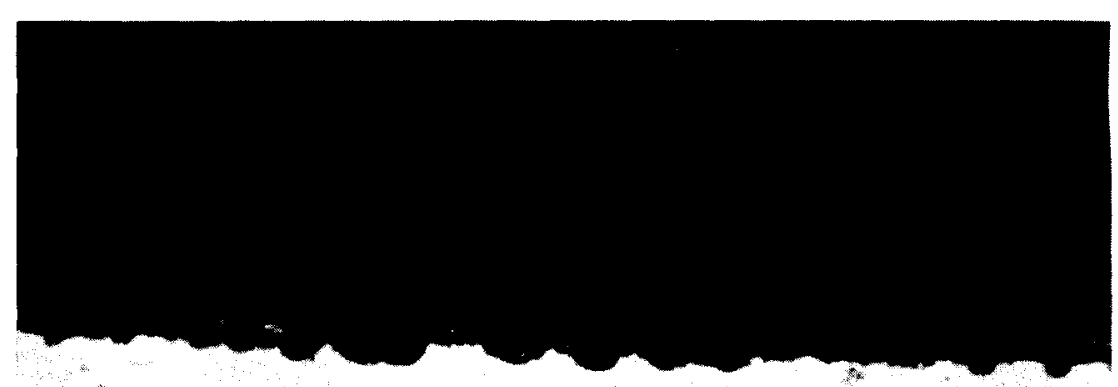

Neg. No. $3 \mathrm{~F}-2$

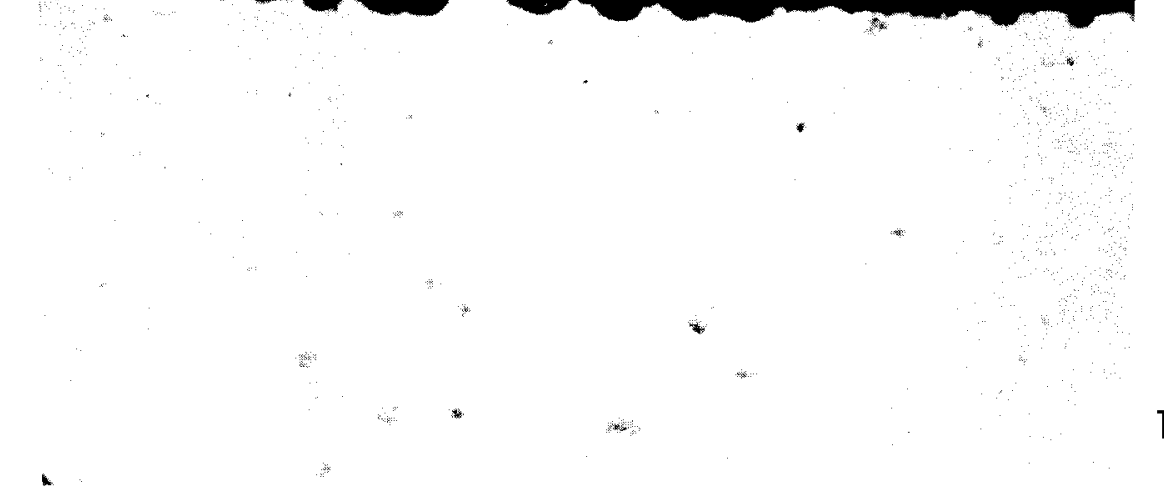

$1000 x$

FIGURE 4. Aluminum Fin Exposed to Rural, High Humidity Environment for 15 Years. $0.12 \mathrm{mil}(3 \mathrm{\mu m})$ 0xide Thickness Covering $0.14 \mathrm{Mil}$ (3.6 $\mathrm{\mu m}$ ) Maximum Pit Depth. 
Four one-foot finned tube specimens (Fig. 5) were placed in various locations at this station in July 1975. These samples consisted of steel tubes completely covered by extruded alloy 6063 aluminum fins. The specimens were mounted in the following locations:

- Tube \#1 - In the hot $\left(130^{\circ} \mathrm{F}, 54^{\circ} \mathrm{C}\right)$, flowing air above one cooler;

- Tube \#2 - In the cool, incoming air below the cooler, not washed when the cooler was washed;

- Tube \#3 - In the cool, incoming air below the cooler, washed when the cooler was washed;

- Tube \#4 - On the site boundary fence.

Samples were taken after one year and again at two years. The most corroded and soiled specimens were those placed beneath the cooling coils in the cool incoming air (Fig. 6). The particular environment of each tube is summarized is Table 3 .

TABLE 3. Summary of Environments and Specimens Placed at a Gas Compressor Station in a Rural, Humid Gulf Coast Location

\begin{tabular}{|c|c|c|c|c|}
\hline Tube Number & 1 & 2 & 3 & 4 \\
\hline Location & Above Cooler & Below Cooler & Below Cooler & Site Fence \\
\hline Temperature & $130^{\circ} \mathrm{F}\left(54^{\circ} \mathrm{C}\right)$ & Ambient & Ambient & Ambient \\
\hline Detergent Washing & Unknown & $\begin{array}{l}\text { Not } \\
\text { Intentional1y }\end{array}$ & Yes & $\begin{array}{l}\text { No (Rain } \\
\text { Only) }\end{array}$ \\
\hline In Flowing Air & Yes (Hot) & Yes (Cool) & Yes (Cool) & No \\
\hline $\begin{array}{l}\text { Contaminant } \\
\text { Deposition }\end{array}$ & Slight & Mild & $\operatorname{Mild}$ & Slight \\
\hline $\begin{array}{l}\text { First Year Corrosion } \\
\text { Evaluation }\end{array}$ & slight & Minor & Mild & slight \\
\hline $\begin{array}{l}\text { Second Year Corrosion } \\
\text { Evaluation }\end{array}$ & Slight & Moderate & Severe & Minor \\
\hline
\end{tabular}




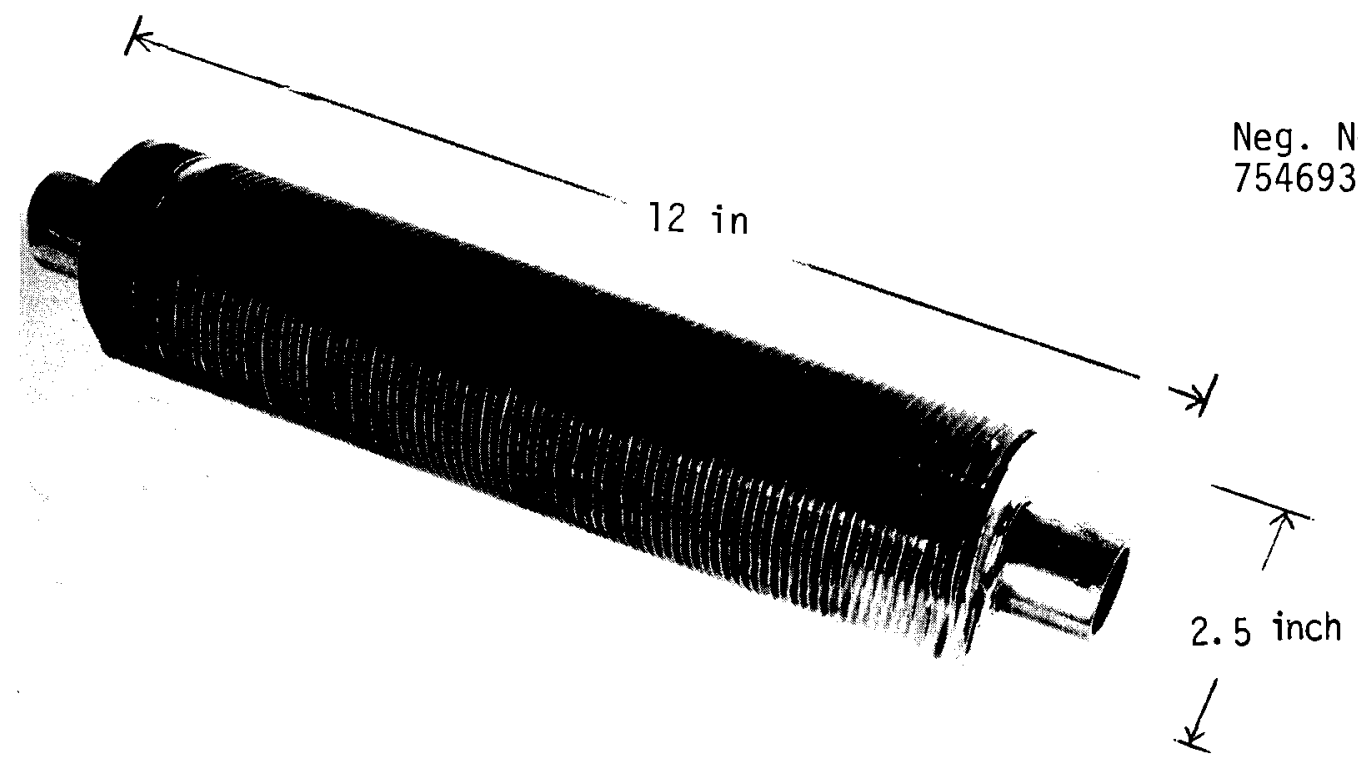

FIGURE 5. Tube Specimen (Al Fins, Steel Tube) Similar to Specimens Installed at Two Gulf Coast Gas Compression Stations.

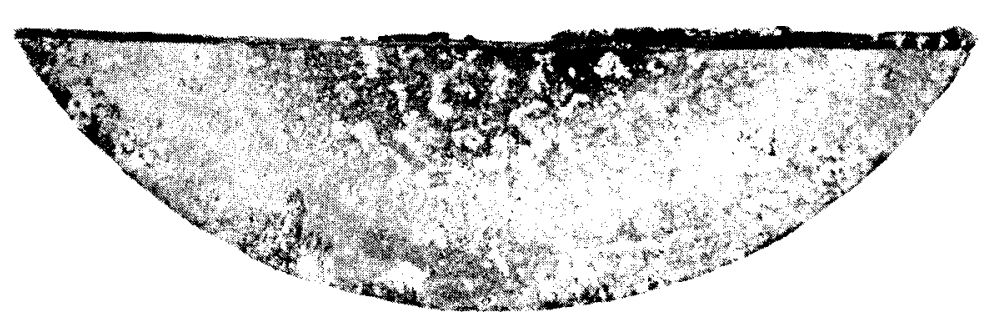

Neg. No. $4 M 1151 \mathrm{~A}$

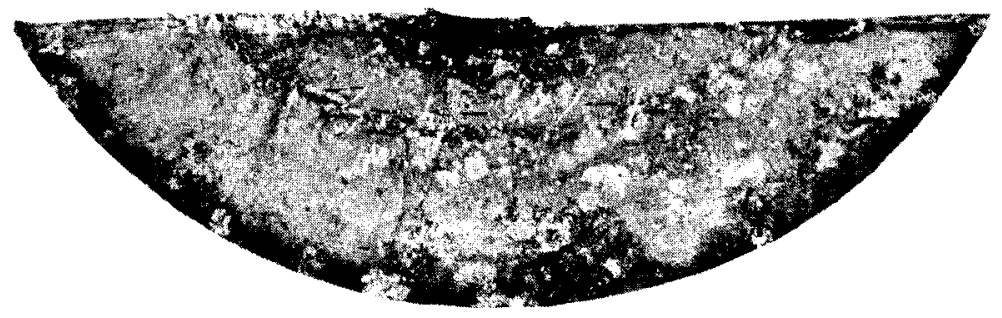

FIGURE 6. Specimen Surface after Two Years of Exposure at Ambient Temperature in a Rural Humid Environment. Top and Bottom are Opposite Sides of Same Fin Showing Different Amounts of Contaminant on Rim. 
A rim section of tube \#1 is shown in Figure 7 . The high temperature and small contaminant build-up has resulted in slight corrosion. Figure 8 shows a rim section of tube \#4. This tube was not washed with detergent nor was it in flowing air. This has resulted in slight contaminant deposition build-up and slight-to-minor corrosion is visible. Note absence of corrosion in crevices presumably caused in forming operations. Where contaminant build-up has been facilitated by the tube being in flowing air and occasionally washed with detergent, then severe corrosion results at ambient temperature as shown in Figure 9 . All second-year specimens were corroded more than first-year specimens. Corrosion on the upper surfaces had progressed substantially during the second year. On all specimens surface pitting was evident in places. Some sub-surface corrosion was noted, but only on the ambient-temperature specimens, subject to spray from cooler cleaning operations. However, participation of the detergent in the severe sub-surface corrosion is not verified. In fact, the specific causes of the corrosion on samples numbered 2 and 3 is not clear.

A SEM micrograph (Fig. 10) is shown of a specimen from tube number 3 after one year of exposure. The grain boundaries were high in silicon and sulfur content as determined by microprobe analysis Surface contamination was also high in silicon and sulfur on the ambient-temperature specimen showing advanced corrosion. Sand and dirt may account for the silicon on the surface; but the source of sulfur contamination is unknown. Aluminum alloy 6063 is expected to have silicon at the grain boundaries as was detected by the SEM microprobe analysis. The $X$-ray fluorescence intensities are provided, and the peak heights are roughly proportional to the weight percent of the element, demonstrating a sulfur gradient though not identifying the sulfur species.

In the samples taken the second year, the most corroded specimens were again those from tube \#3, in the cool, incoming air below the cooler, washed when the cooler was washed with an industrial detergent. The effect of the washing is particularly evident in that the bottom edges of the fins are very corroded and far more soiled than the top surfaces. This could result from drainage of the detergent solution to the bottom of the fin. Whether or not the detergent is aggressive to the aluminum is unclear. Corrosion has completely 


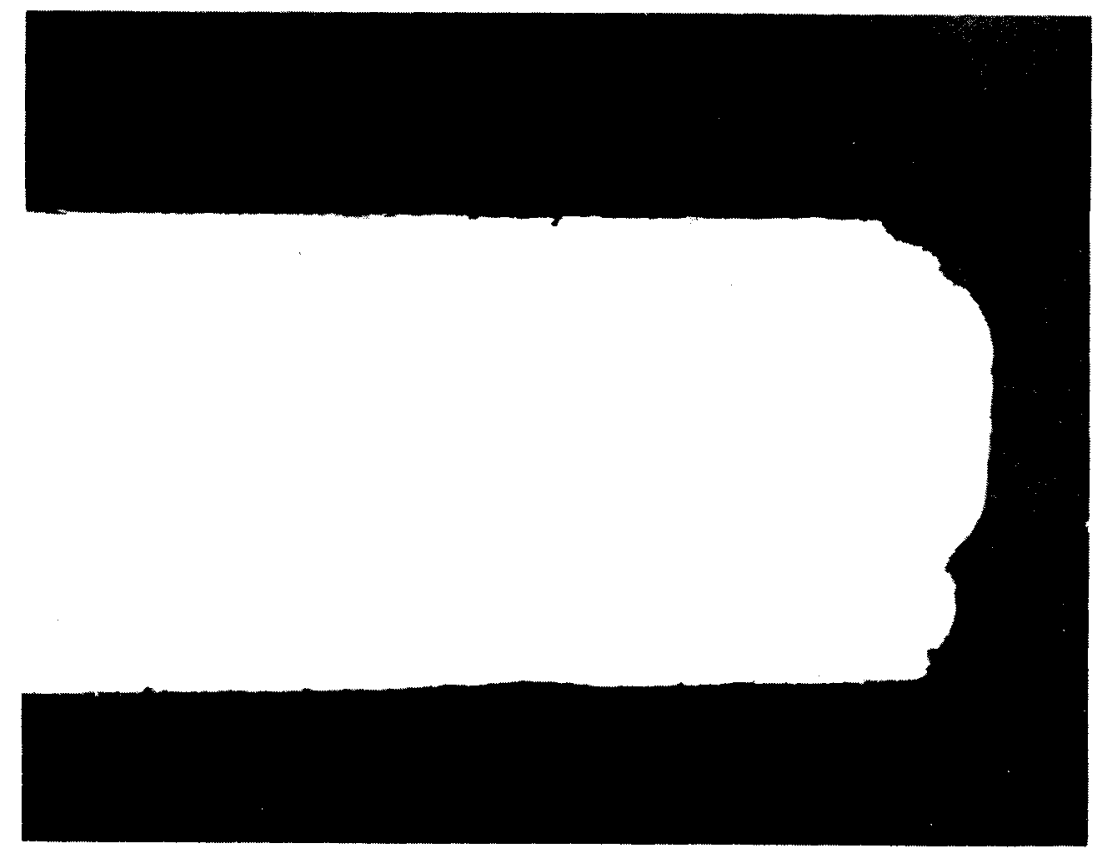

Neg. No.

4M1090A

FIGURE 7. Aluminum Fin Exposed at Air Cooler Temperature $\left(130^{\circ} \mathrm{F}\right.$, $54^{\circ} \mathrm{C}$ ) for Two Years to a Rural-Humid Environment at a Gas Compressor Station in Mississippi, Near the Gulf Coast

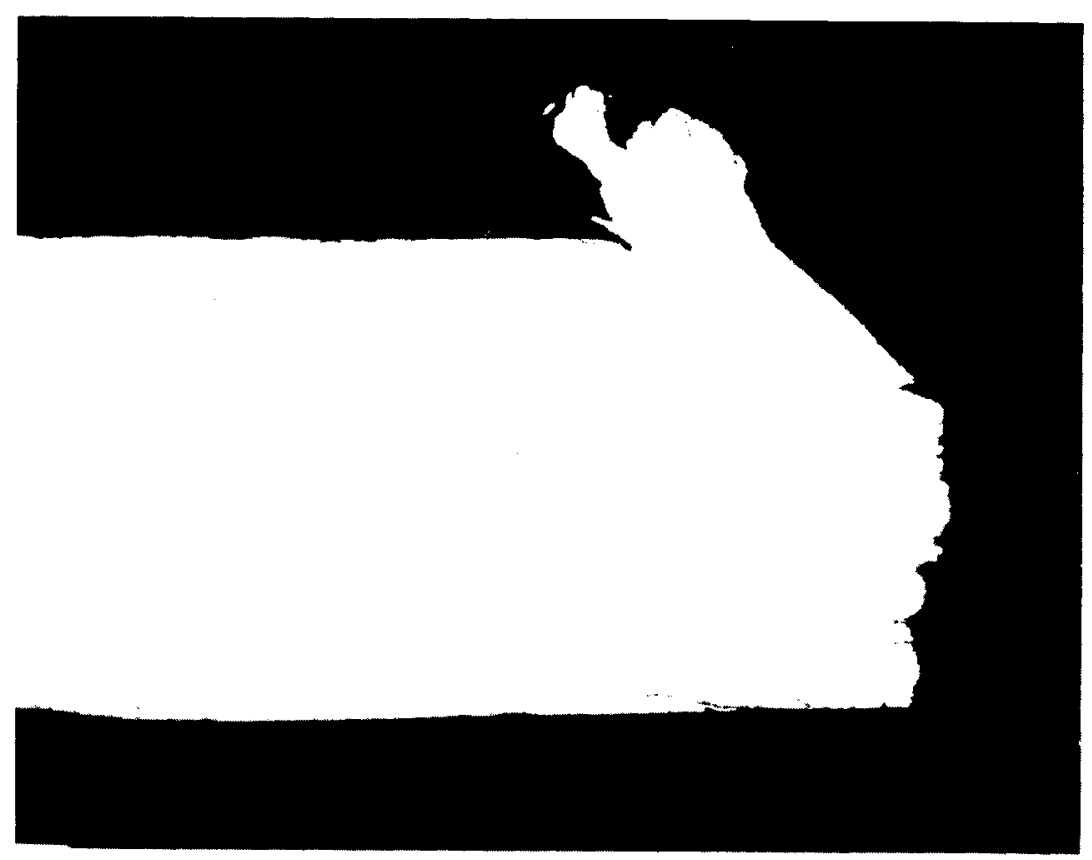

Neg. No.

$4 M 1094 \mathrm{~A}$

$200 x$

FIGURE 8. Aluminum Fin Exposed Only at Ambient Temperatures and Subjected Only to Rain Washing for Two Years at a RuralHumid Environment 


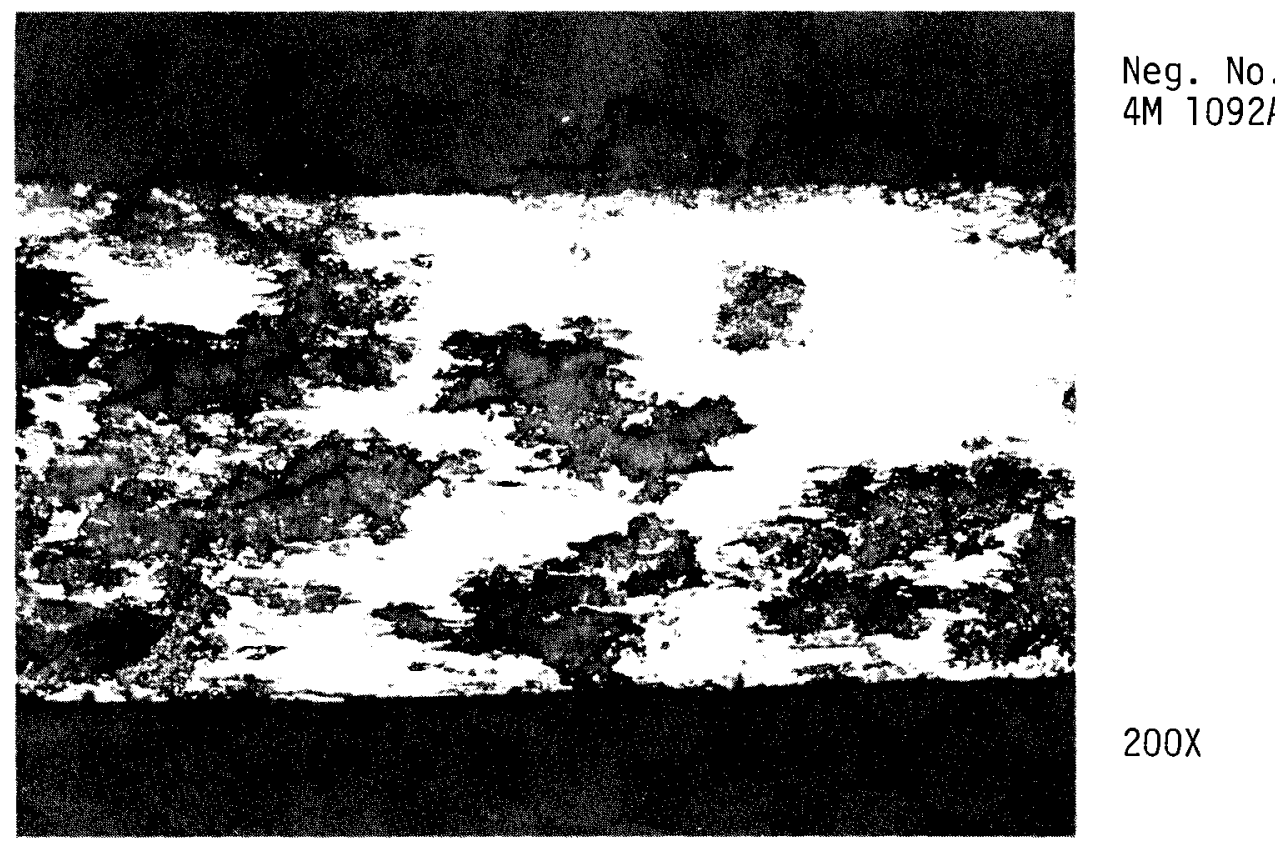

FIGURE 9. Aluminum Fin Exposed Only at Ambient Temperatures - Subject to Spray from Cooler Cleaning Operations During Exposure for Two Years to a Rural-Humid Environment at a Gas Compressor Station in Mississippi Near the Gulf Coast 
Oxide

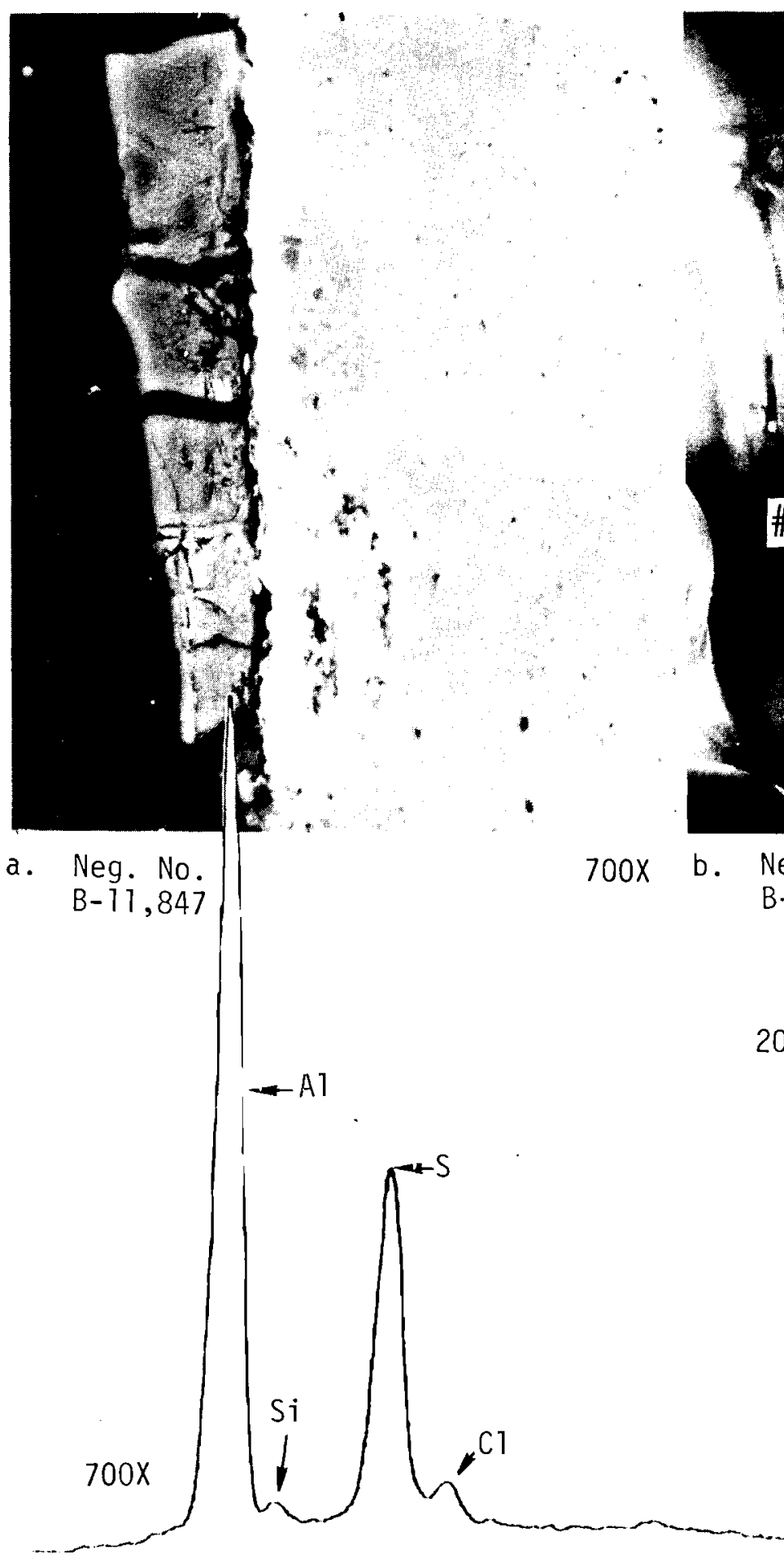

Al Metal

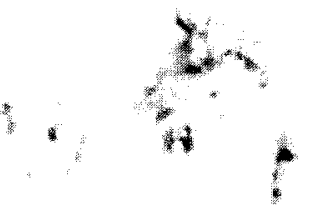

$2000 x$

(3)

\#2

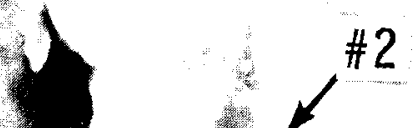

$0+33^{2}$

1

$2000 x$

c. Microprobe Analys is \#1

d. Microprobe Analysis \#2

FIGURE 10. SEM Micrographs and Microprobe Analys is of an A1 A1loy 6063 Fin Specimen Exposed One Year in a Rural Humid Environment.

a) General View of Area b) Specific Area where c) Analysis \#1 of Surface Oxide and d) Analysis \#2 of Internal Corrosion Product Were Taken 
penetrated the bottom edge of the fin in places. The samples from the other two ambient tempera ture locations show very little corrosion after two years. The importance of this effect is that it serves to concentrate the soluble contaminates on the bottom edge of the fin and especially on the side away from the water source. The most troublesome contaminate, $\mathrm{NaCl}$, may readily concentrate in this way, and could account, at least in part for the observed distribution and severity of corrosion.

\subsection{INDUSTRIAL, ARID ENVIRONMENT}

\subsubsection{West Central Texas}

A natural gas company in Texas employs dry coolers to cool compressor engine jacket water and oil cooling water in an industrial, arid environment. The station compresses so-called "sweet" natural gas; there is very little $\mathrm{SO}_{2}$ or $\mathrm{H}_{2} \mathrm{~S}$ contamination in the plant area.

Fin specimens were taken from two operating coolers. The first had operated for about two years and consisted of aluminum fins wrapped onto 90/10 copper-nickel tubes. The surface of these fins was bright and corrosion-free. The second unit had been in operation for 22 years and was constructed of aluminum fins wrapped onto Admiralty brass tubing. The fins showed very little corrosion, principally some slight discoloration on the outer edges. A fin from the second unit (22 year) is shown in cross section in Figure 11; Figure 12 shows an oxide film thickness on the fin of about 0.05 mils. No pitting of these fins was observed, though some indents from mechanical damage are evident on Figure 11.

\subsection{INDUSTRIAL, HUMID ENVIRONMENT}

\subsubsection{Ibbenbüren, Germany}

The Preussag Power Plant at Ibbenbüren, Germany, is an indirectcycle dry-cooled plant of the Heller-Forgo design. This design involves a carbon steel spray condenser with stainless steel nozzles, which inject cooled condensate into steam to condense it as it exits from the turbines. The condensate is pumped to the cooler to dissipate the heat absorbed from the steam. The tower has aluminum tubes and plate-type aluminum fins. The tubes

are vertical and the fins are horizontal. (3) A section of this tower is shown in Figure 13. 


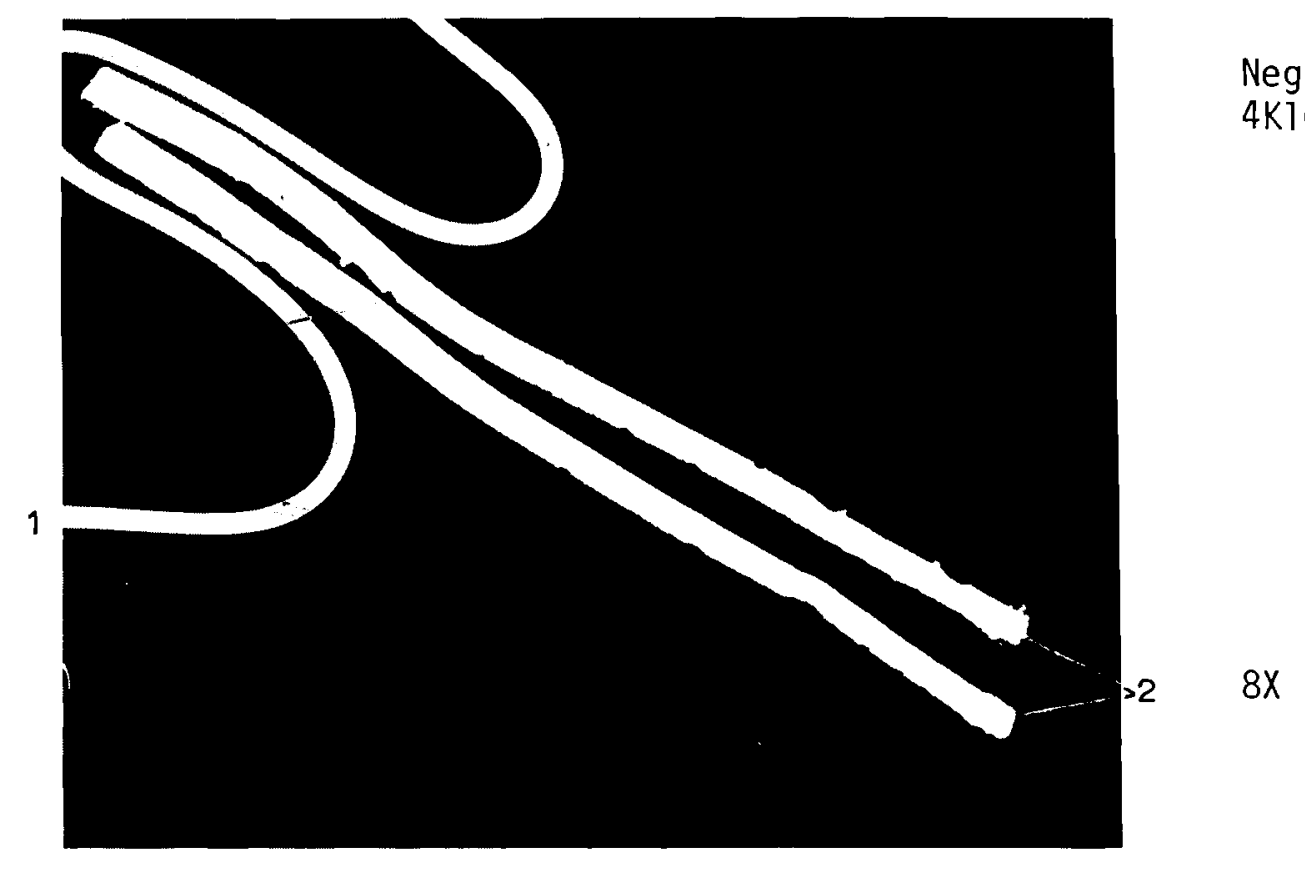

FIGURE 11. Aluminum Fins Wrapped on Admiralty Tubing Exposed for 22 Years to a Low $\mathrm{SO}_{2}$, Low $S$ Atmosphere. 1) Metallographic Mounting Clip. 2) Outer Edge of Fin.

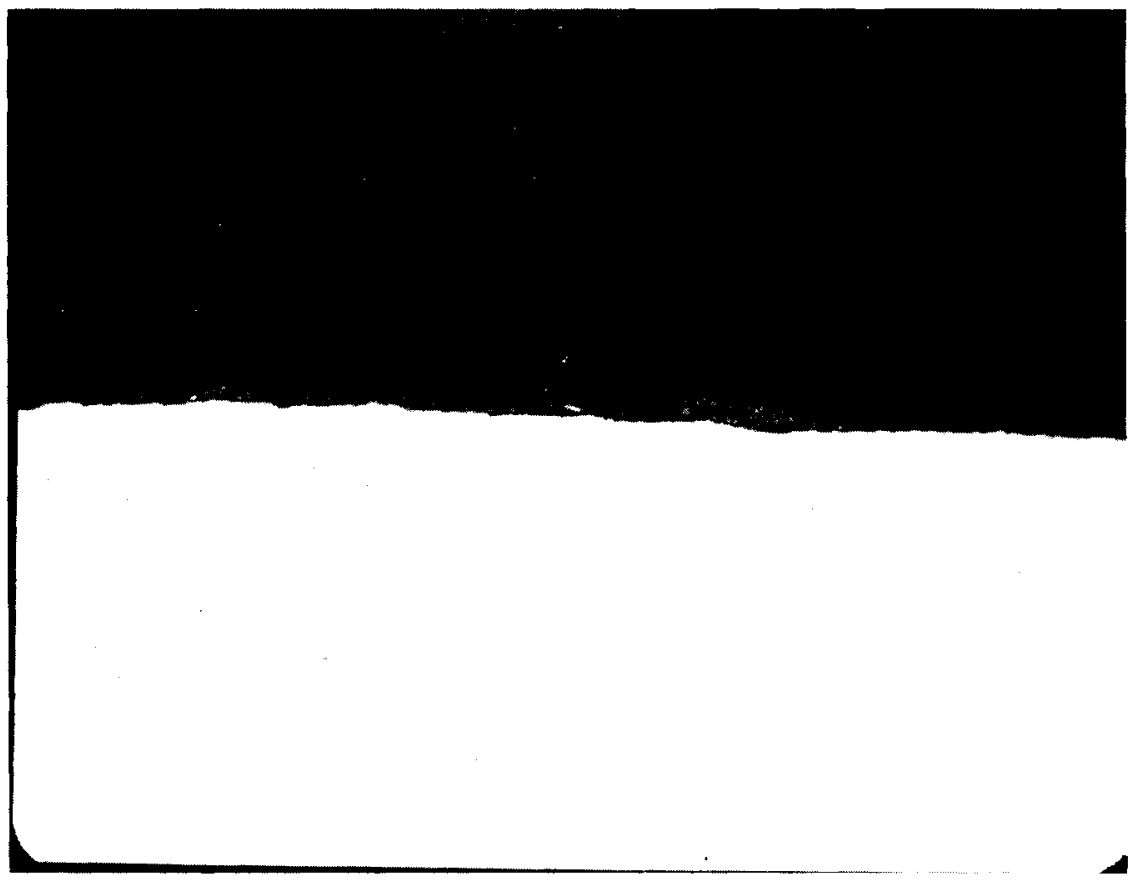

Neg. No.

$4 \mathrm{I}$

$1000 x$

FIGURE 12. Oxide Thickness on Aluminum Fins Shown in Figure 11 is $0.05 \mathrm{Mil}$ $(1.3 \mu \mathrm{m})$. No pitting is evident. 
The dry-cooled power station has serious fouling problems resulting from proximity to pulverized coal storage areas and wet cooling towers. (1) The situation is aggravated by the notched fins, which act as effective dirt traps. Since the aluminum Forgo-type fins cannot withstand cleaning by pressurized water, cleaning with pressurized air has been attempted several times with negligible effect. Removal of the bundles for cleaning may be necessary. The combination of fouling and corrosion has reduced the heat rejection capacity of the Ibbenbüren plant to $75 \%$ after eight years of operation. (2) The fouling by coal dust is shown in Figures 14 and 15 .

Examination of a fin/tube cross section reveals that severe corrosion has occurred, as shown in Figures 16, 17 and 18. However, corrosion occurred only under those regions covered by coal dust. Figure 16 shows that no corrosion occurred in the crevices between the fin + spacer, fin + tube, or spacer + tube (region A in micrograph).

Scanning electron microscopy and microprobe analysis (Figure 17) revealed a large variety of constituents in the coal dust. Chloride and sulfur appear to be potentially the most significant from the standpoint of corrosion. Sulfur and chlorine are found deep in the corrosion product, suggesting that they probably participated in the corrosion reaction.

The scale build-up on the water-side of the tube was 0.0007 in. $(0.7 \mathrm{mil}$ or $18 \mu \mathrm{m}$ ) (Figure 19), SEM microprobe analysis indicated that the scale has significant iron content, presumably due to corrosion product transport from the steel components in the circuit.

\subsection{MARINE, MOIST ENVIRONMENT}

\subsubsection{Southern California Coast}

Fin samples of 1100 series Aluminum were obtained from a compressor station on the southern coast of California. The fins had been in a moist marine environment up to 20 years. The rainfal1 is low (12 in./year, $30 \mathrm{~cm} /$ year), but the cooler is located $21.4 \mathrm{~km}$ from the Pacific shoreland and is subject to frequent fogs and mists. The average humidity is 71 percent. The station operator reported that no corrosion problems were noted on the fins, but the steel supporting structures had corroded considerably. The air cooler is on line only about $25 \%$ of the time and is otherwise on cold stand-by. 


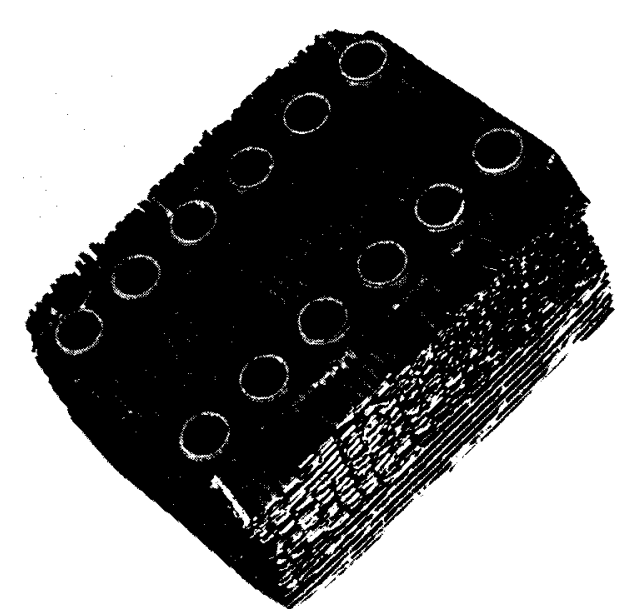

Neg. No.

SAMPLE 6A

PLANT: PREUSSAG AG POWER PLANT

LOCATION. IBBENBUREN. GERMANY

SYSTEM TYPE. HELLER FORGO INOIRECT

TUBE FIN MATERIAL: ALUMINUM ALUMINUM

FIN TYPE: FORGO PLATE TYPE

COMMENTS: SERIOUS FOULING BY COAL DUST

754693-13

$0.32 X$

FIGURE 13. Section of Dry Cooling Tower from Ibbenbüren, Germany

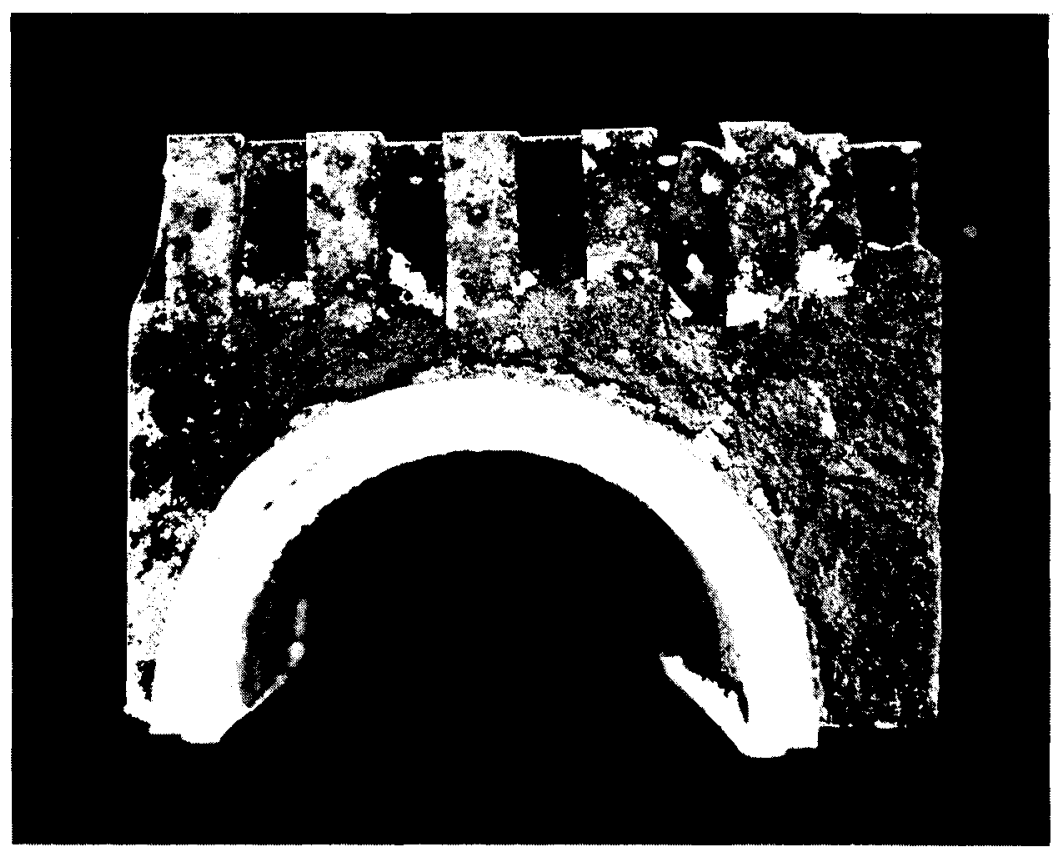

Neg. No. 4K1042A

\section{$3.5 X$}

FIGURE 14. Close-up of Coal Dust Fouling on Aluminum Plate-Type Fin. 


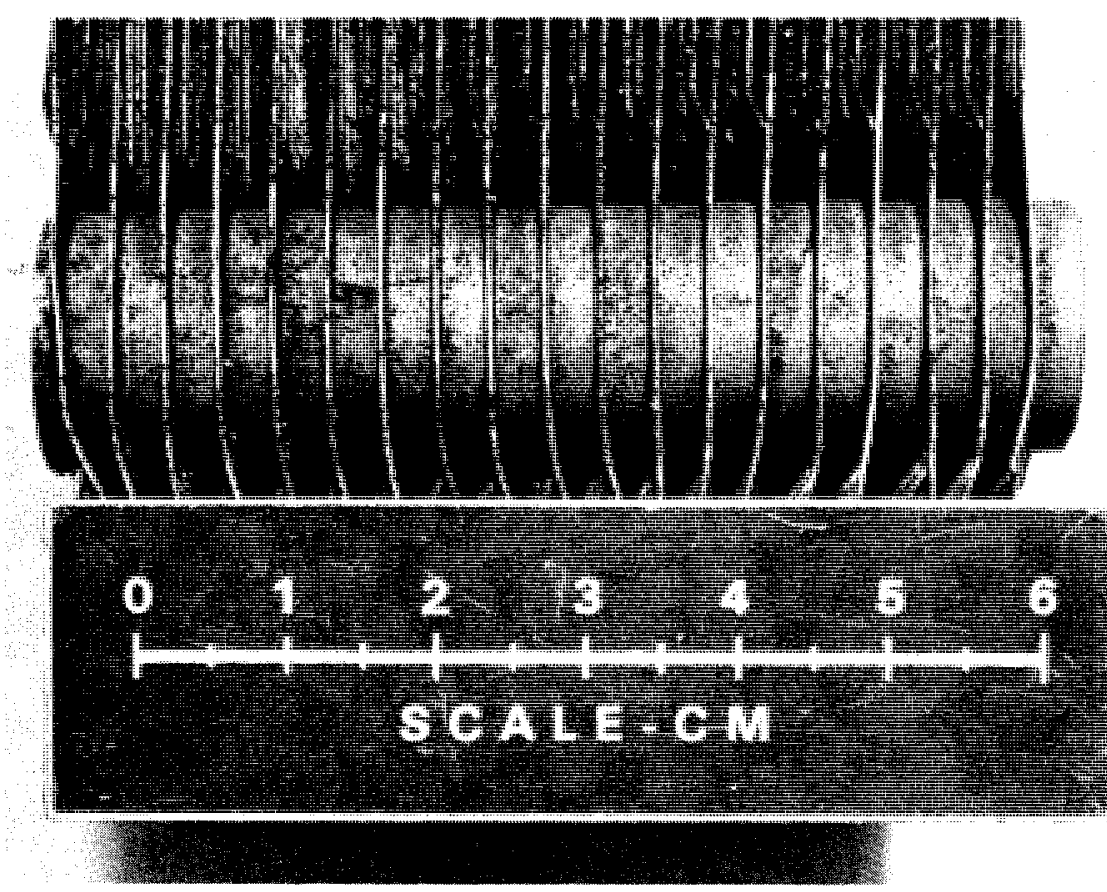

Neg. No.

754693-3

FIGURE 15. Cooler Section Showing Alternate Layers of A1 Plates and Spacers Stacked Around A1 Tubes. Coal Dust fouling is evident.

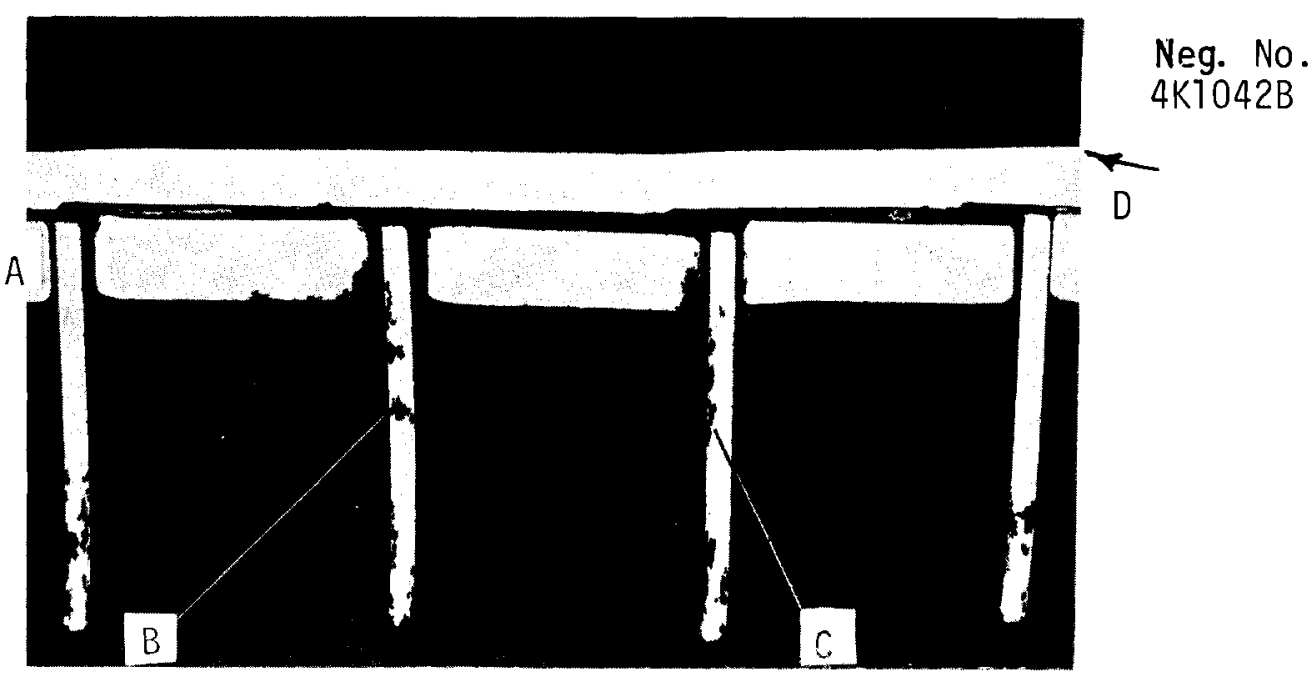

FIGURE 16. Metallographic Section Through Tube, Spacer, and Fin Plate on Section of Aluminum Cooling Tower. Note Severe Corrosion on Fins under Coal Dust and Lack of Corrosion on Inner Surfaces (Area A) Where No Coal Dust Was Present. For B, refer to Figure 17; for $C$, refer to Figure 18; and for $D$, refer to Figure 19. 


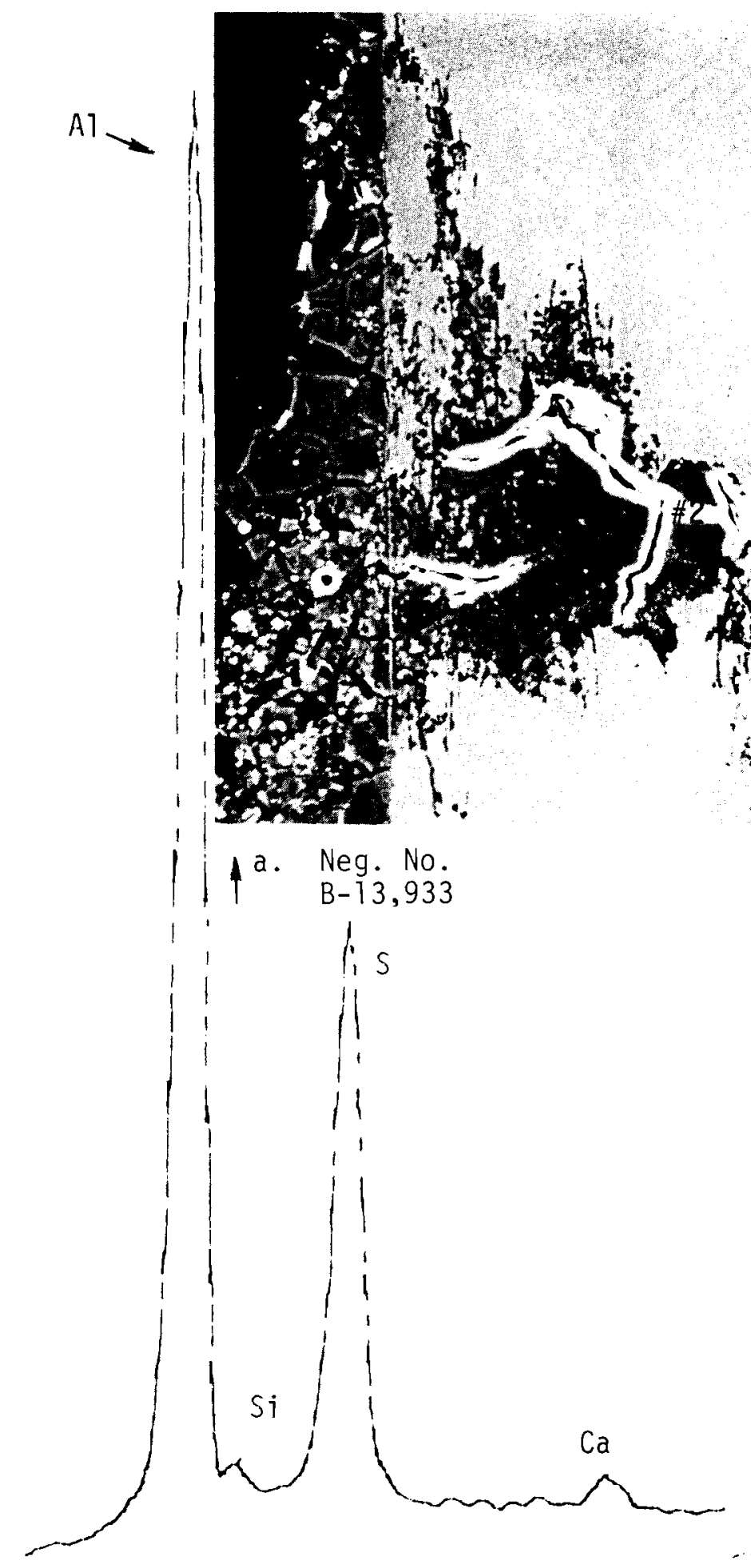

at

A1

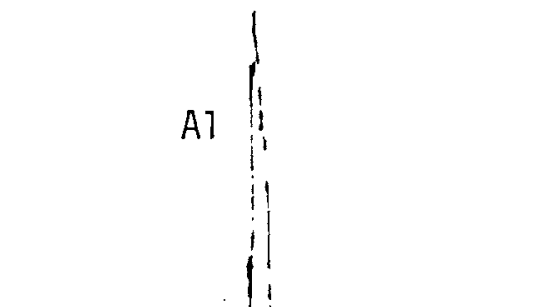

b. Analysis $\rightarrow$ \# 1 (F in)

$(1 / 2$ scale)

$180 x$

c. Analysis \#3 (Surface Corrosion)

d. Analysis \#2 (Deep Corrosion)

FIGURE 17. a) SEM Micrograph Showing Locations of Microprobe Analysis

(Area B of Figure 16). b) Analysis \#1 of Fin Metal.

c) Analysis \#3 of Corrosion Product at Surface. d) Analysis \#2 of Deep Corrosion Product 

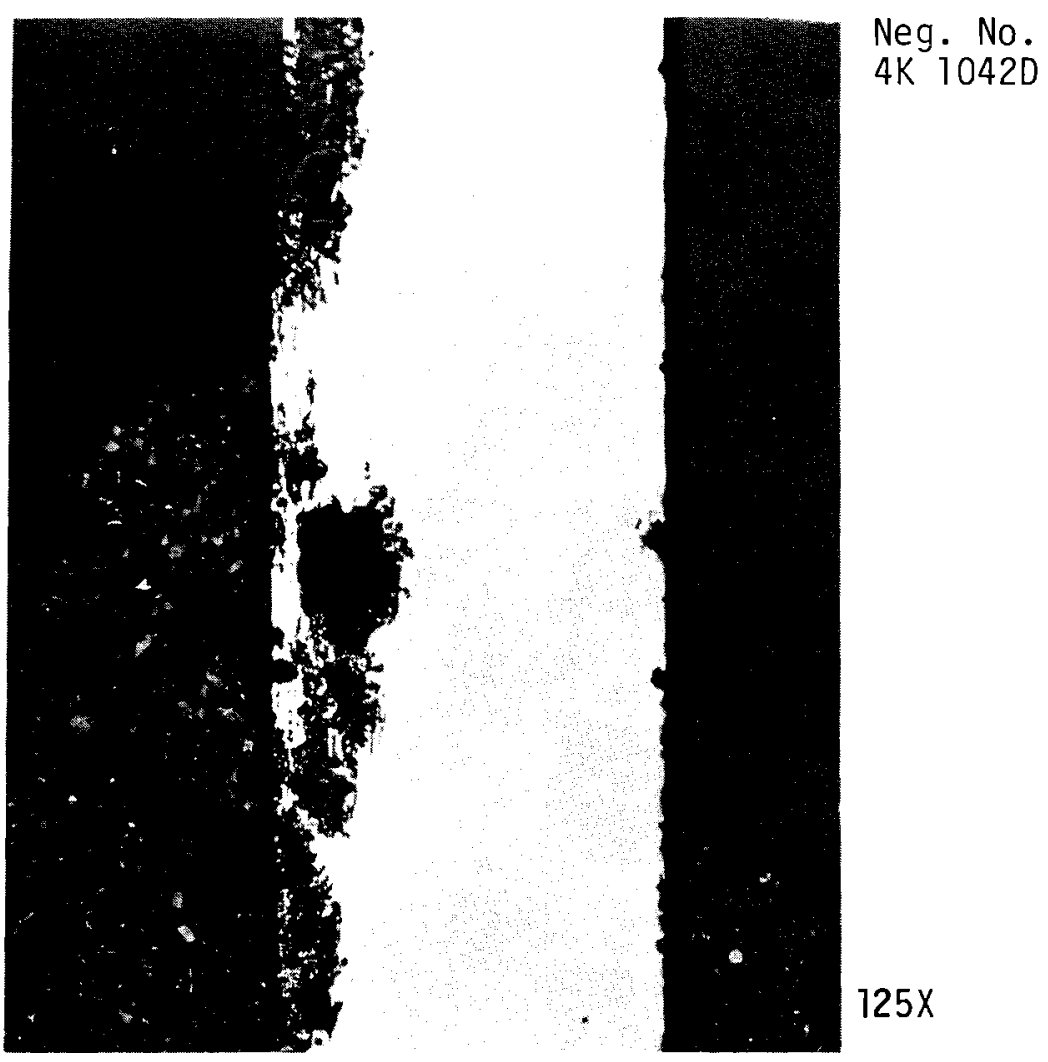

FIGURE 18. Close-up of Region C in Figure 16 Showing Severe Corrosion Under Coal Dust Deposit. Note: Etched View Shown in Figure 45.

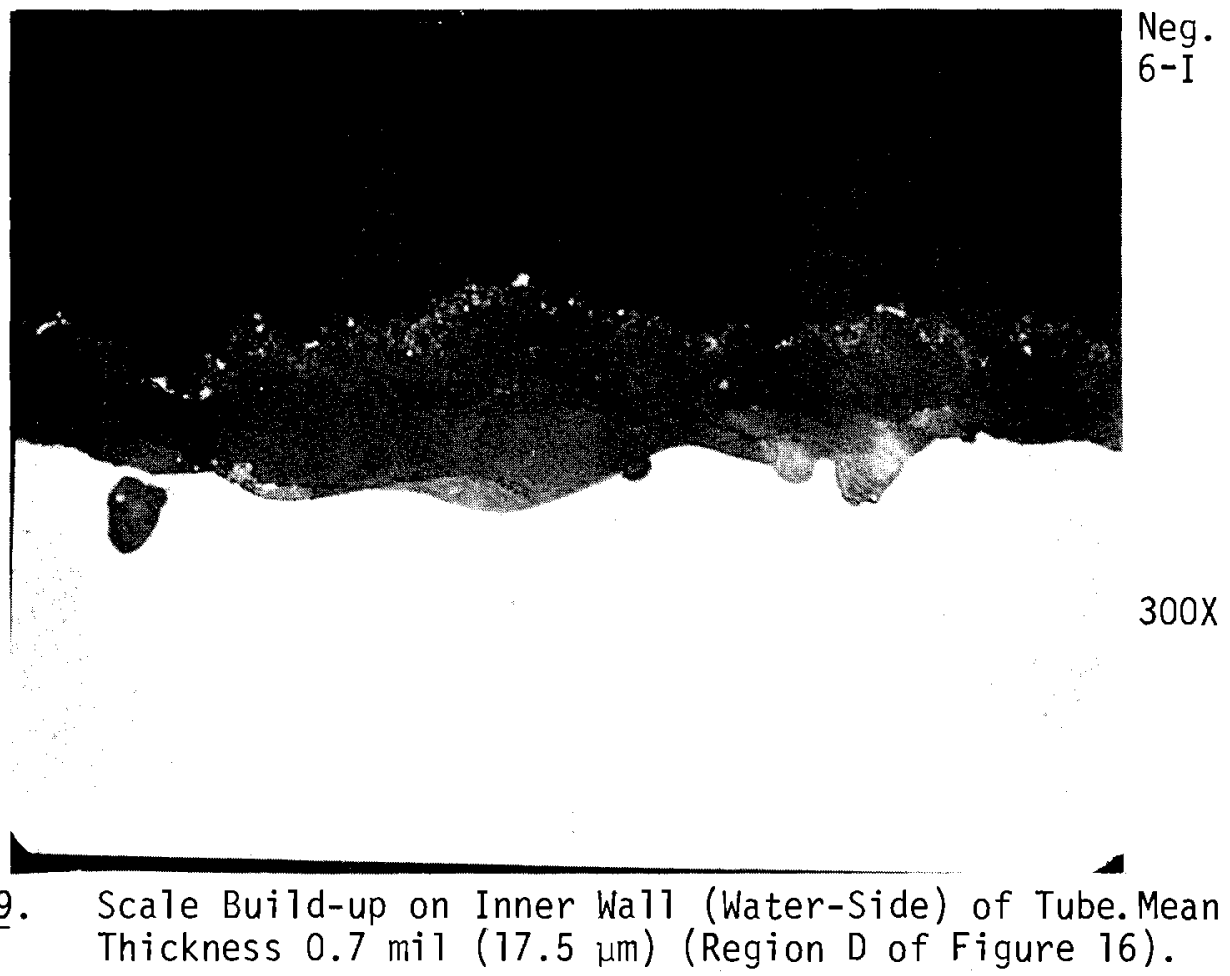


Some paint was evident on the aluminum fins, presumably from overspray from painting of the steel supporting structures.

Corrosion was largely sub-surface. (Fig. 20), resembling the corrosion found on other aluminum fins described in this report (e.g., Fig. 18). Corrosion of the fins appeared to be most severe near the tip. The amount of corrosion shown (Fig. 21) has not begun to noticeably influence cooler performance. However, whether the sub-surface corrosion is intergranular or transgranular has not been clearly established.

\subsection{MARINE, HUMID, INDUSTRIAL ENVIRONMENT}

\subsubsection{Gulf Coast Area of Louisiana}

A natural gas compressor station similar to that described in Section 4.1 .2 is operated in a marine, humid, industrial atmosphere along the Louisiana Gulf Coast. A sulfur mine, processing plant and shipping dock are located about 3.5 miles $(5.6 \mathrm{~km})$ to the south; the prevailing wind blows northward from the sulfur plant to the compressor station. Oyster shells are used as a ground cover. Dust from the shells is present in the atmosphere, particularly during dry weather.

\subsubsection{Corrosion of Original Dry Coolers}

Four coolers of the unitized design were originally installed at this site, two in 1961 and two in 1963. Tubes were Admiralty, fins were aluminum, (1130 type aluminum alloy) solder-bonded to the tubes. These four units developed cooling problems starting about three years after installation, due to fin deterioration caused by corrosion. The fins on the lower banks of tubes came loose from the tubes. The corrosion was not restricted to the base but was sufficiently concentrated near the base that fin detachment occurred. However, solder did not appear to participate in the corrosion attack.

Figure 22 shows the appearance of the cooling fins on the top and bottom bank of tubes after 13 years of service. Gross corrosion is evident: the fins on the lower tube detached completely from the tube. Note that corrosion was much more severe on the lower tube bank which may have acted like filters in the induced draft. 


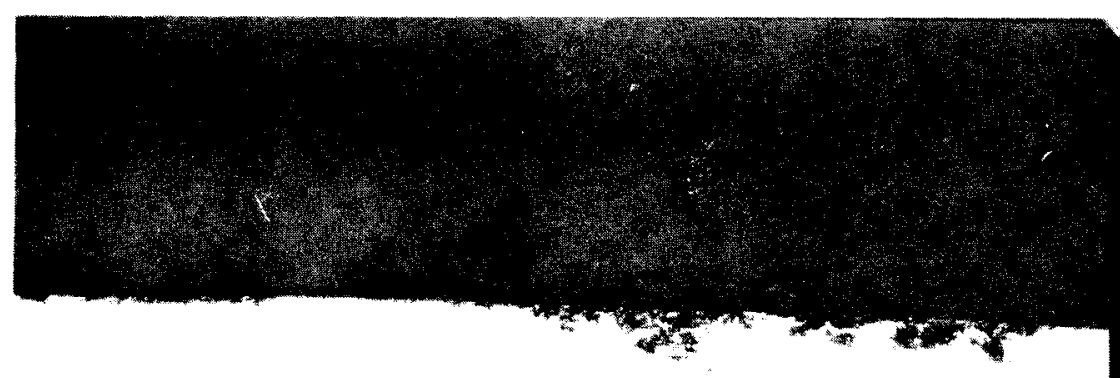

Neg. No.

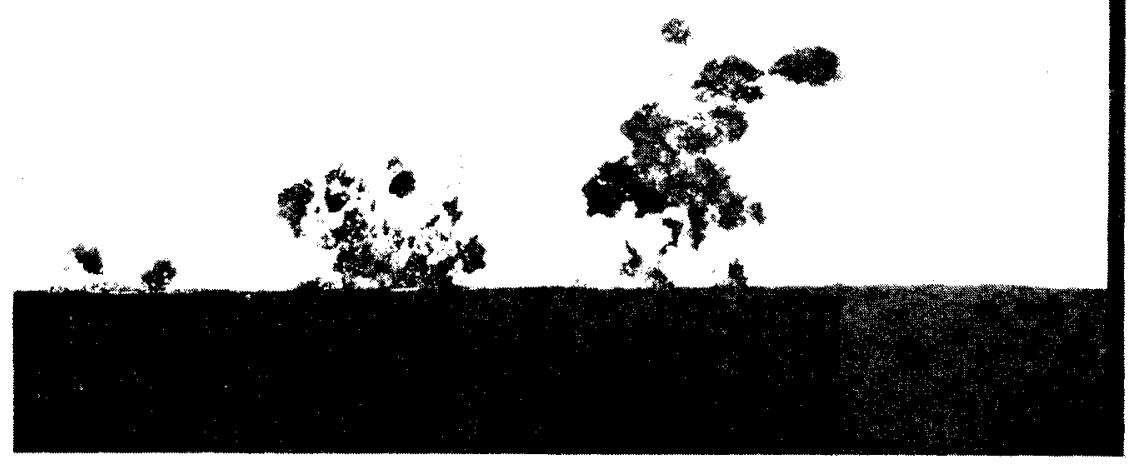

$100 x$

FIGURE 20. Aluminum A1loy 1100 Fins Exposed for 20 Years in a Moist Marine Environment. Sub-surface corrosion is similar to corrosion found on other samples (e.g., Figure 18)

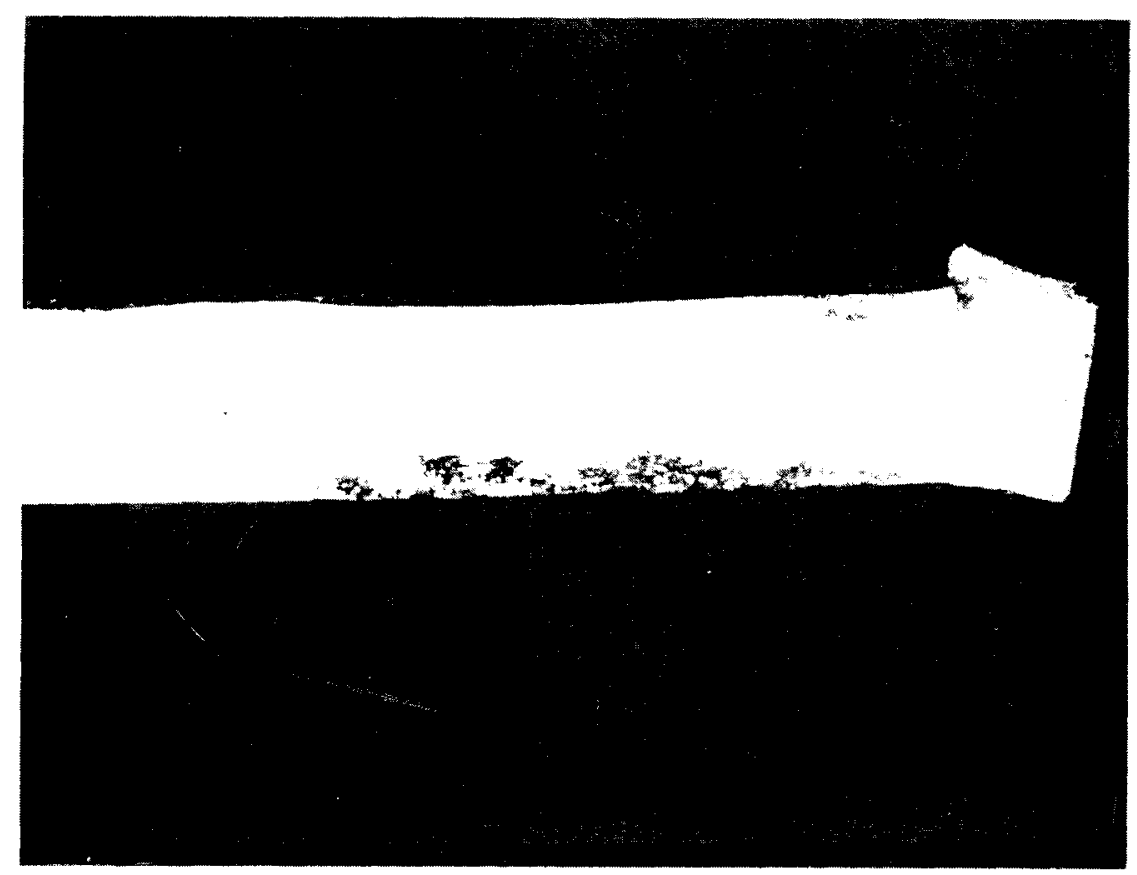

Neg. No. $19-1$

$100 x$

FIGURE 21. Sub-surface Corrosion, Concentrated Near the Tip of the Fin Shown in Figure 20 
Figure 23 shows substantial corrosive attack near the solder joint, though evidently not involving the solder itself. * A close-up of the corrosion is shown in Figure 24 and Figure 25 is an etched view of a fin, showing the intergranular nature of the corrosion.

Scanning electron microscopy and microprobe analysis indicated that sulfur and lead were the major impurities at the grain boundary locations in the fins from the upper tube bank, while sulfur, lead, and calcium were present in the lower tube fins (Fig. 26).

A unit with extruded aluminum fins on Admiralty brass tubing has operated for nine years with the result that the Al fins underwent intergranular type corrosive attack at the outer periphery (see Fig. 27). Approximately $20 \%$ of the fin surface area was covered by corrosion products, predominantly at the outer edge of the fin.

Two units with wrap-on type fins on Admiralty tubing were operated for 4 and 5.9 years with the inlet/outlet temperatures at $125^{\circ} \mathrm{F} / 115^{\circ} \mathrm{F}\left(52^{\circ} \mathrm{C} / 46^{\circ} \mathrm{C}\right)$. Fins from both these units underwent severe intergranular type attack, with complete fin penetration in some areas. The attack was somewhat more intense at the base of the fin near the tube than at the outer periphery. Sixty to seventy percent of the fin surface area of the units was covered with corrosion patches, predominantly at the outer periphery (Figure 28).

\subsubsection{Corrosion of Aluminum Finned Tube Specimens Placed at Site Discussed in Section 4.6.1}

Four tube specimens were placed at the compressor station discussed in the preceeding section. These tubes were extruded A1 6063 alloy fins on carbon steel tubes, of the same type shown in Figure 5 on page 14. These specimens were mounted in the following locations.

- Tube \#1 - In the hot, flowing air above the engine cooling tubes

- Tube \#2 - Below the cooling coils in the cool incoming air

\footnotetext{
${ }^{\star} 80 \% \mathrm{~Pb}, 20 \%$ sn solder alloy
} 


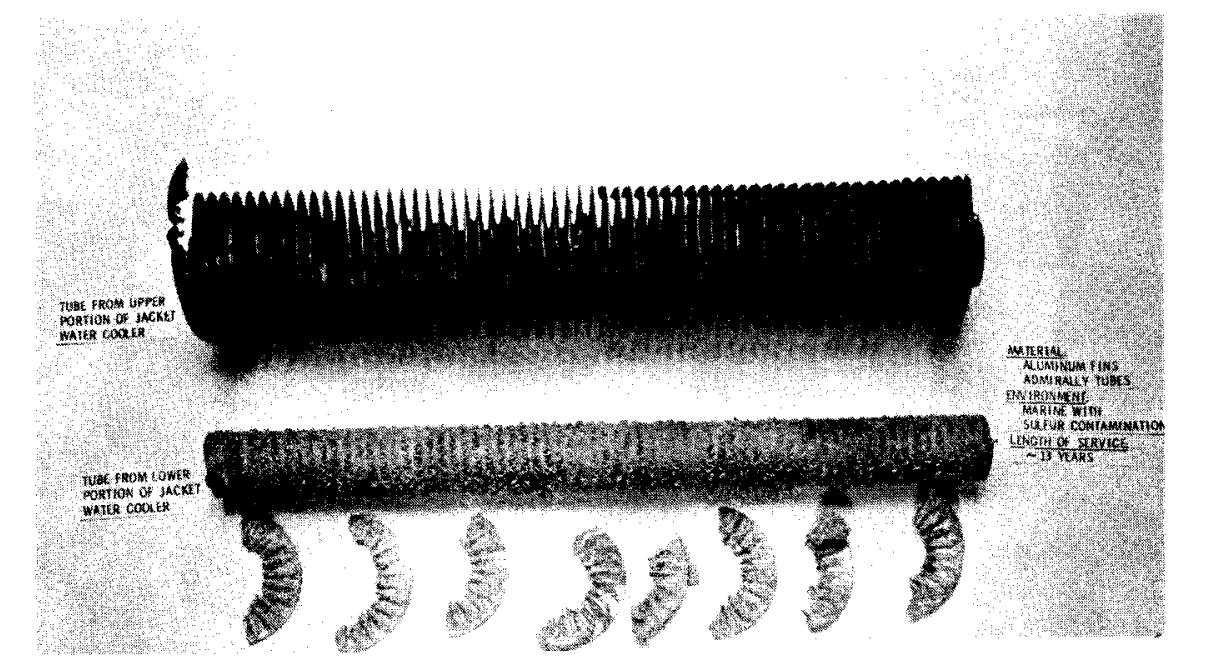

Neg. No. 752079-1

FIGURE 22. Aluminum Fins after Exposure for 13 Years to a Humid Marine Environment ( $\mathrm{CaCO}_{3}, \mathrm{Cl}$ and $\mathrm{S}$ Contamination). Fins detached from lower tube.

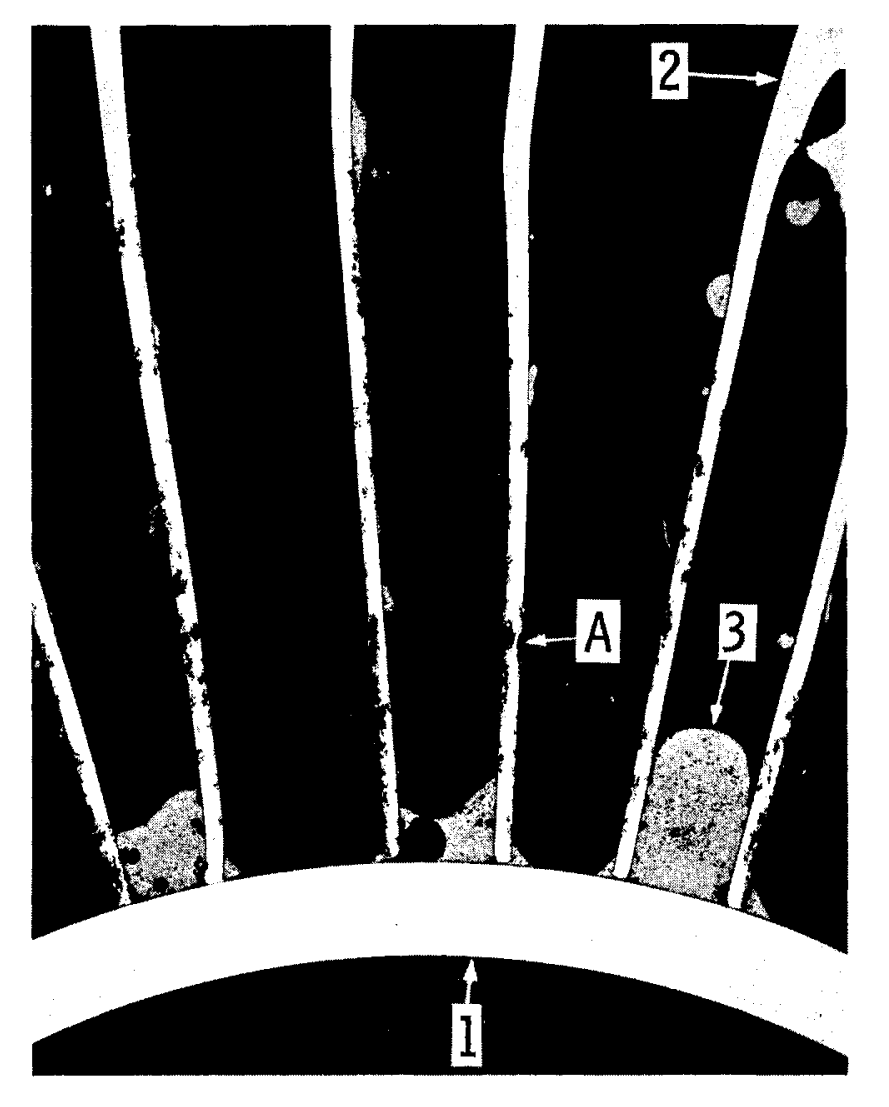

Neg. No. $4 \mathrm{~K} 468 \mathrm{~A}$

FIGURE 23. Metallographic Section Through a Tube from the Upper Bank, Refer to Figure 22. Shows corrosion along the length of the fin and not associated with the solder. 1. Tube. 2. Fin. 3. Solder. Area $A$ is enlarged in Figure 24. 

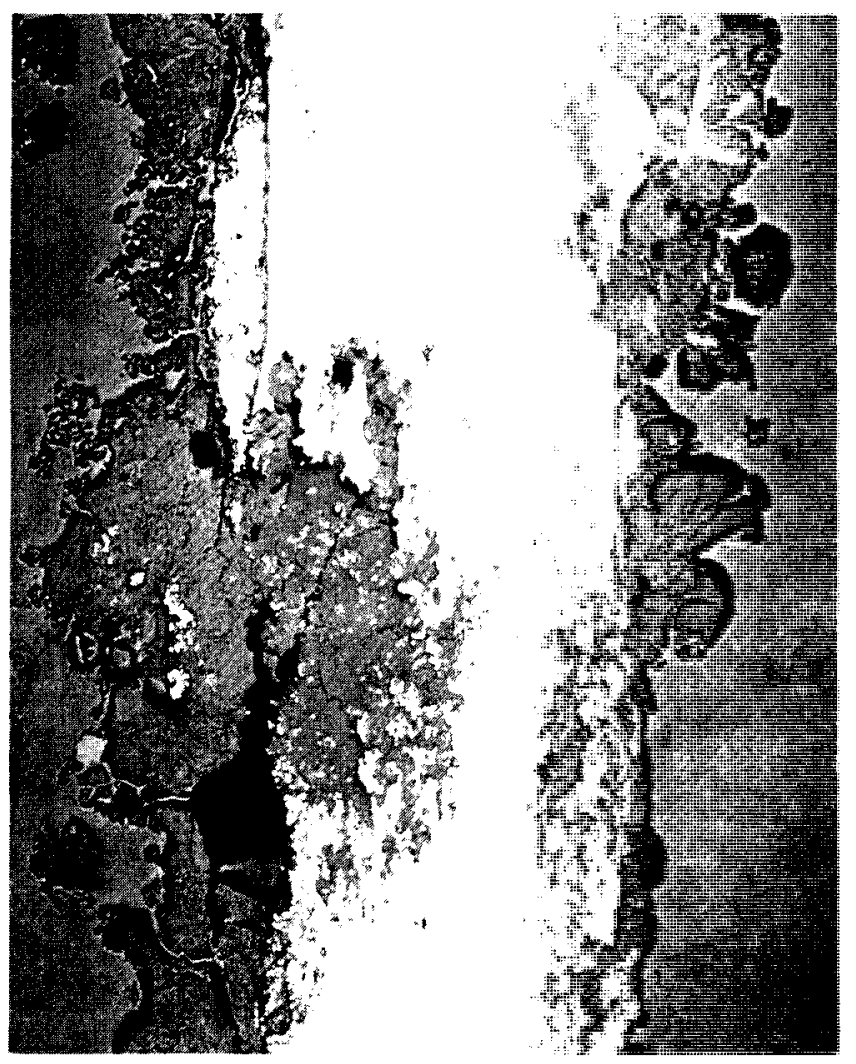

Neg. No.

$4 \mathrm{~K} 468 \mathrm{~F}$

\section{FIGURE 24. En1argement of \\ Region A in Figure 23 Showing Severe Attack After 13-Year Ex- Posure to a Humid Marine Environment}

$150 x$

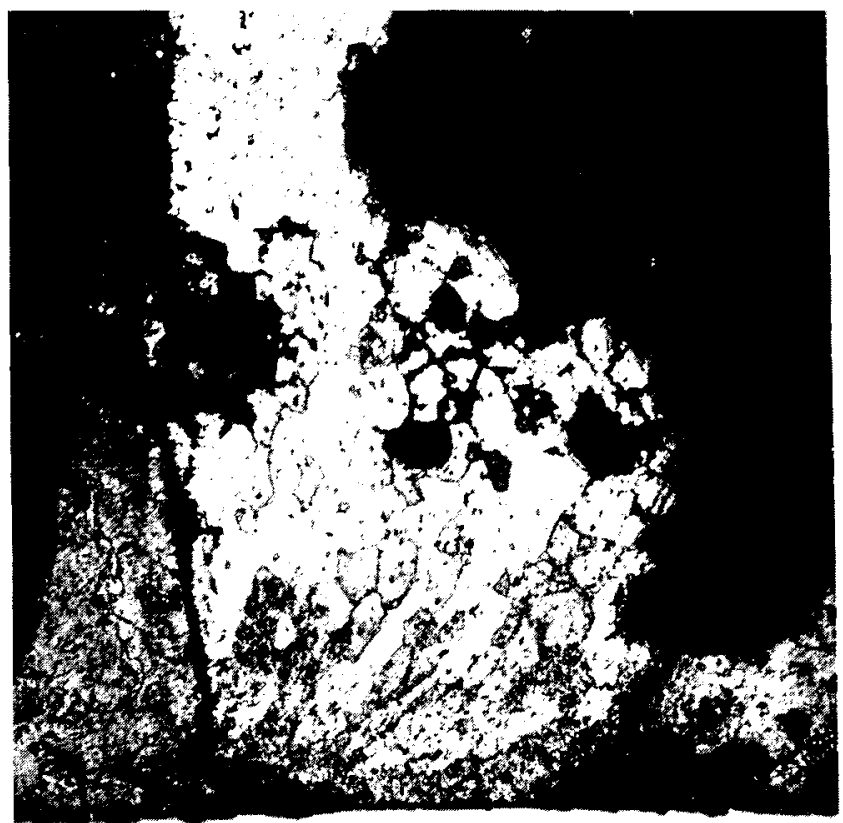

Neg. No.

$4 K 473 I$

FIGURE 25. An Etched View of a Fin in Figure 23 Showing Intergranular Nature of Corrosion

\section{Etched Fin.}

Etchant: Keller's Etch

Etch Time: $10 \mathrm{Sec}$ Immersion

Admiralty Tube Metal 


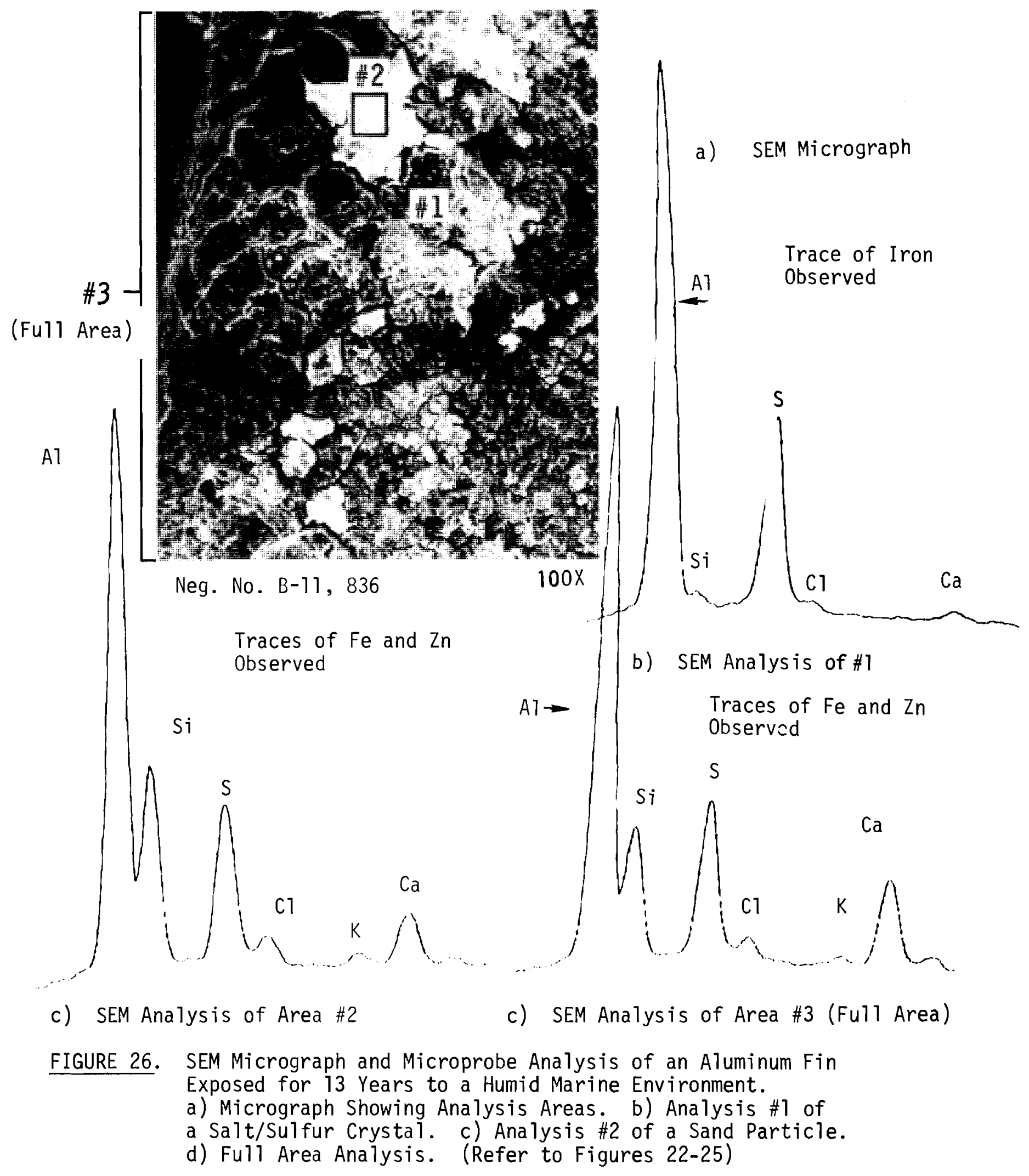




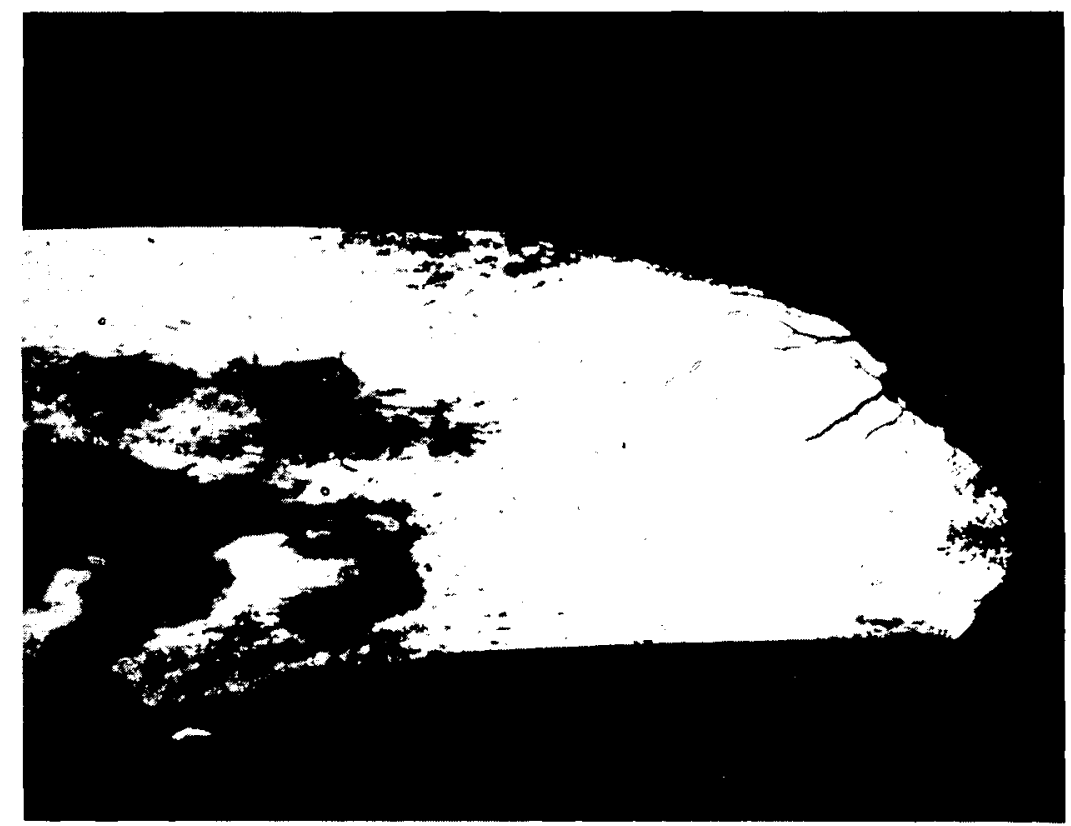

Neg. No. $4 \mathrm{~K} 1037 \mathrm{~F}$

$250 x$

FIGURE 27. Outer Edge of Fin Exposed for 9 Years to a Humid MarineEnvironment. Note that Crevice Corrosion Did Not Develop in Extrusion Cracks at the Fin Tip.

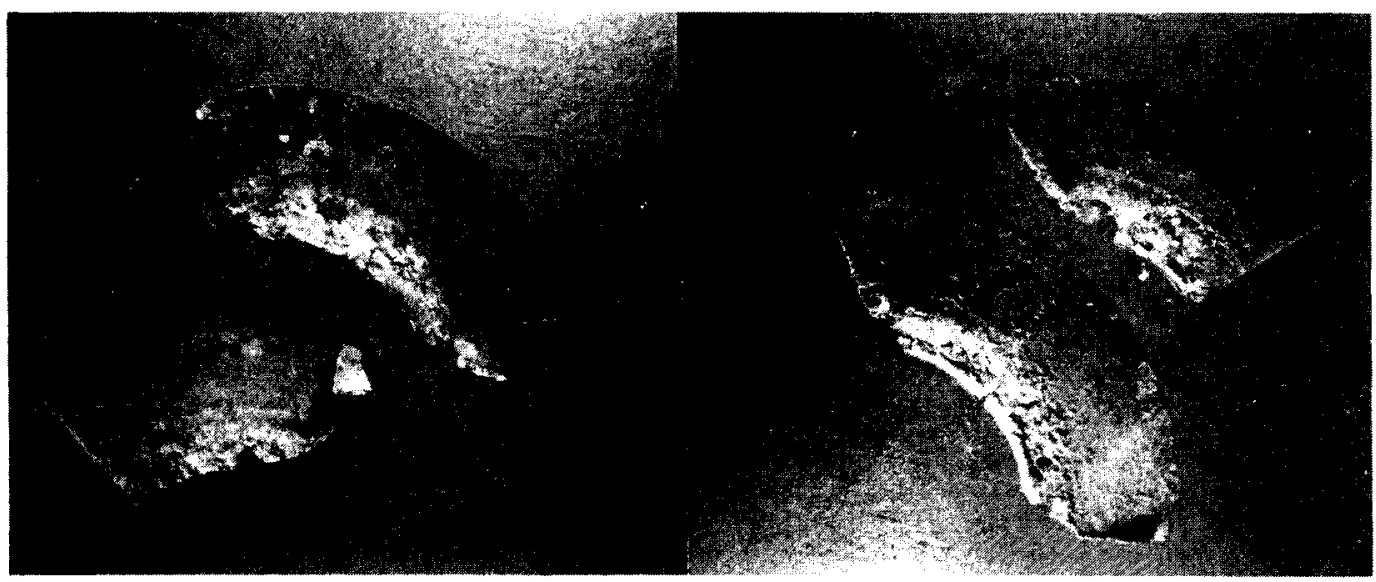

Neg. No. $3 C-1,-2$

FIGURE 28. Micrographs Showing Opposite Sides (Left and Right) of the Same Two Fins. Note Rim Build-up (Heavier on Left) and Corrosion at the Base of the Fin. 
- Tube \#3 - In the cool incoming air below the cooling coils of cooler closest to salt spray from Gulf of Mexico

- Tube \#4 - Attached to plant headquarters building - control specimen at ambient temperature.

Specimens taken from the tubes after one year were examined metallographically and again after two years (Fig. 29 and 30).

The most discolored fins were those found beneath the coolers in the cold air stream (Fig. 31 and 33). These fins had the most salt, dirt, and particulate matter deposits. The lower coils would effectively act as filters in the updraft. Insufficient or ineffective washing, dispite the 50 inches of rainfall, would allow a rapid deposit buildup. The more soiled fins also showed the most corrosion, perhaps due to poultice induced corrosion. These test specimens appeared very similar to those discussed in Section 4.2.1.

The corrosion was sub-surface, resembling the intergranular corrosion found on fins from the compressor station air coolers (Fig. 22-28). This is not suprising because the 6063 alloy is known to undergo intergranular corrosion with precipitation of silicon along the grain boundaries. (11) Scanning electron microscopy and microprobe analysis revealed that the salt-like surface deposits contained significant sulfur; sulfur was also present with silicon at the grain boundaries (Fig. 33). However, the chemical state of the sulfur is not clear. Silicon (probably sand) was also found on the surface. Chlorine was detected on the surface and in the corrosion products on the fin.

\subsubsection{Rugeley, England}

The central power station at Rugeley, England, includes an indirect-cycle dry-cooled, 120-MWe plant of the Heller-Forgo design, similar to the plant at Ibbenbüren.

The Rugeley plant has experienced serious air-side corrosion. The station is located at the site of a coal mine and is also adjacent to an ash sintering plant which makes light weight aggregate from the plant ash. Also, the dry tower is in close proximity to four evaporative towers and is subject to drift and spray from them. Within a short time after startup, serious 
Neg. No.

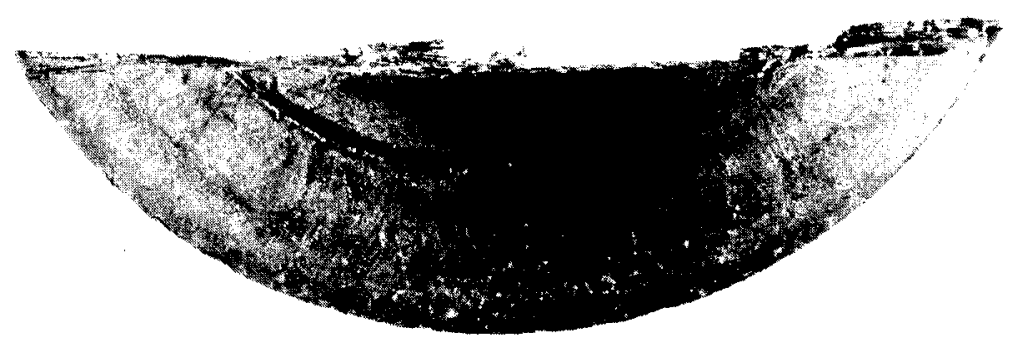

$4 M 1150 A$

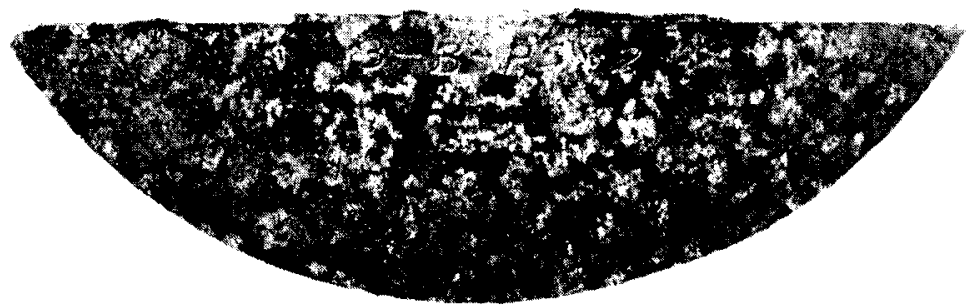

$2 X$

FIGURE 29. Aluminum Alloy 6063 Fins Exposed for 2 Years to a Humid Marine Industrial Environment. Top Fin at Dry Cooling Tower Temperature Still Has Some Luster. Bottom Fin at Ambient Temperature in the Cooling Incoming Air is Heavily Contaminated.

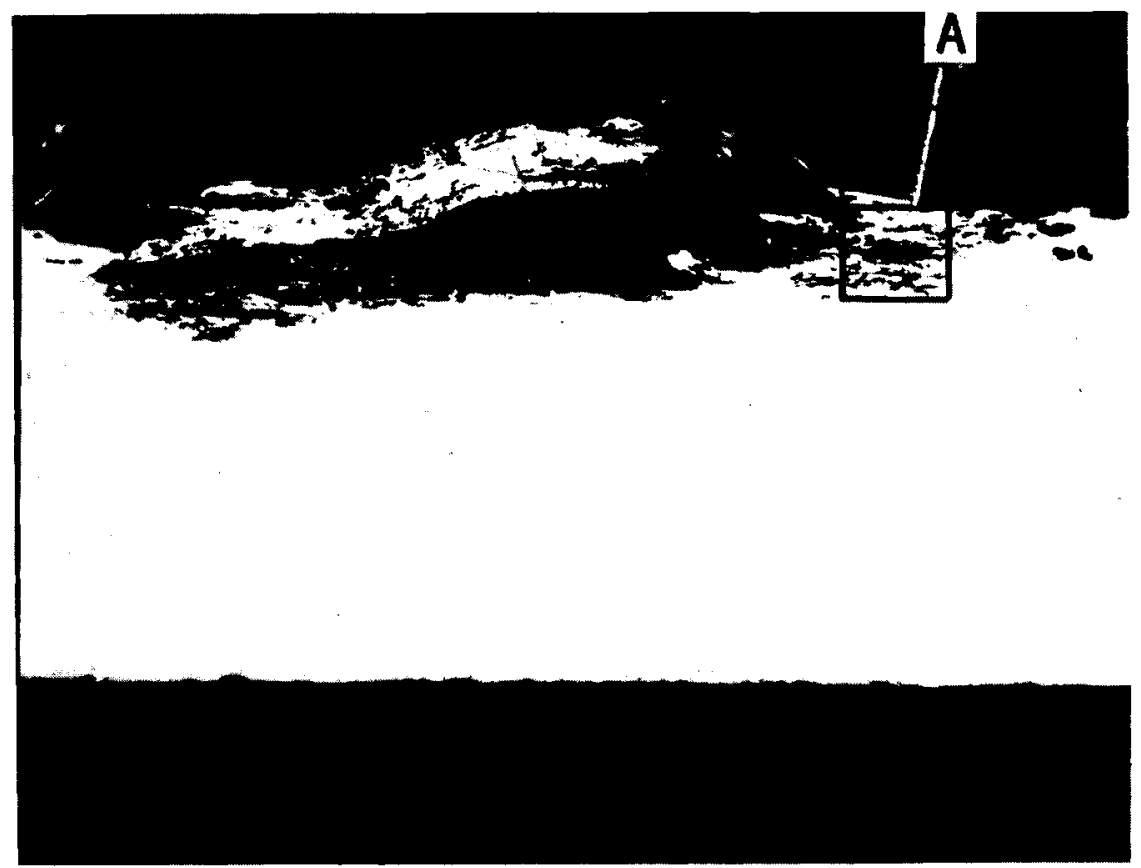

Neg. No. $17 \mathrm{DB}$

$200 x$

FIGURE 30. Aluminum Fin Placed in a Humid-Marine Environment under an Atmospheric Cooler. Shows sub-surface corrosion after one year. Figure 33 is a close-up of Region A. 


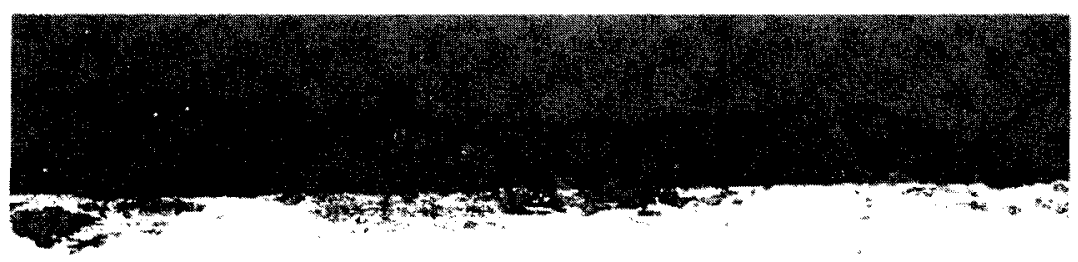

Neg. No.

$4 M 11470$

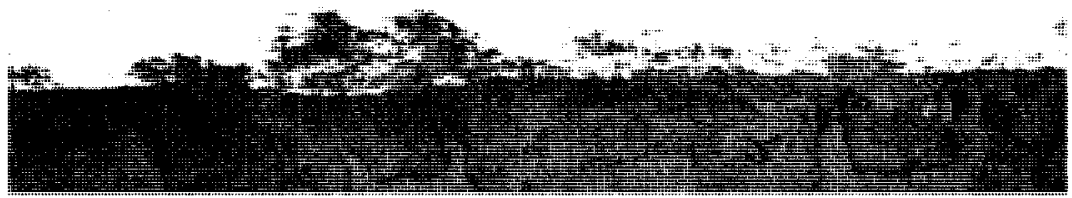

$200 x$

a. Upper Fin Edge

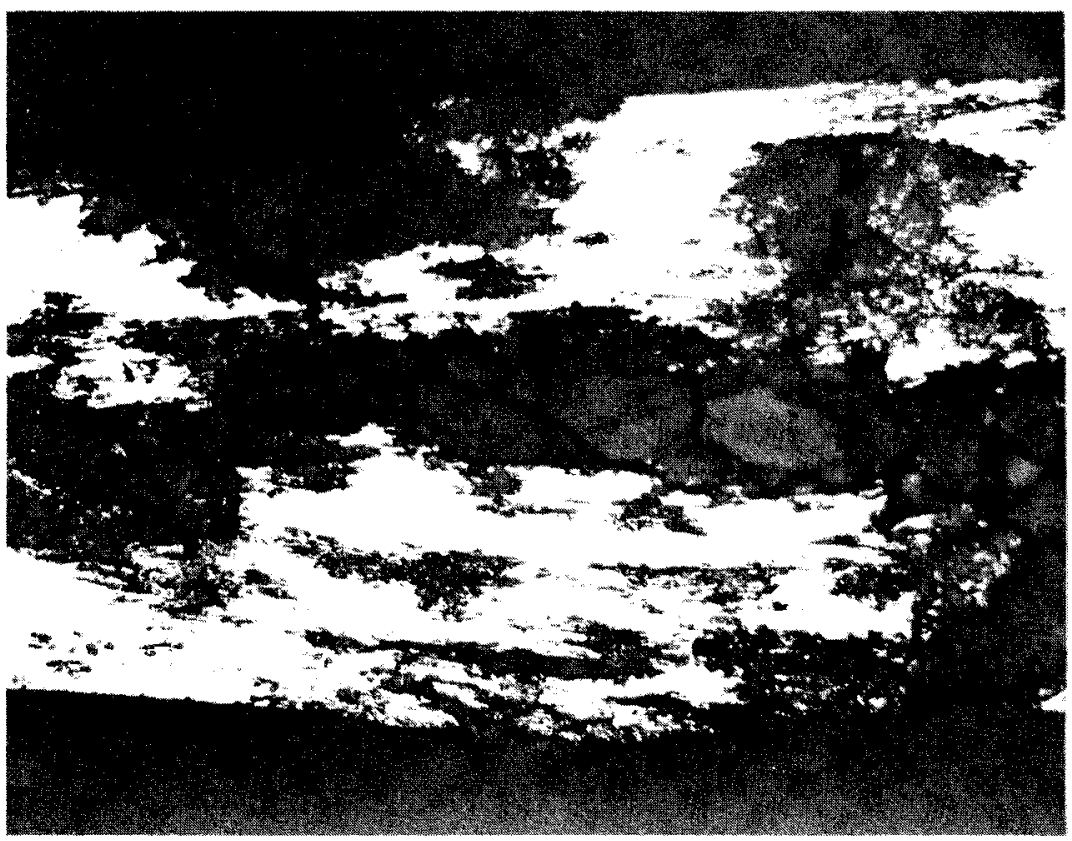

Neg. No. $4 M 1148 A$

$200 x$

\section{b. Lower Fin Edge}

FIGURE 31. Aluminum A11oy 6063 Fins Exposed for Two Years to a Humid, Marine Industrial Environment. Both fin sections are from same tube (\#3); a) fin edge from top of tube; b) fin edge from bottom of tube, showing greater corrosion caused by higher contaminant concentration on lower edge of fins. 


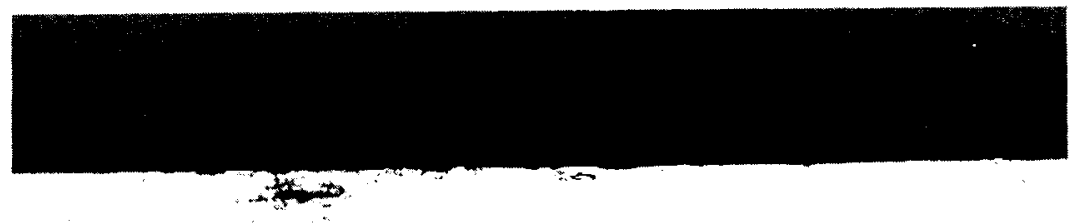

Neg. No.

$4 M 1145 \mathrm{~A}$

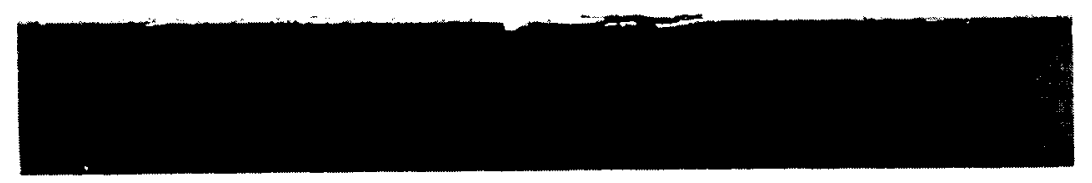

$200 x$

a. Operated at $\sim 115-125^{\circ} \mathrm{F}\left(46-52^{\circ} \mathrm{C}\right)$

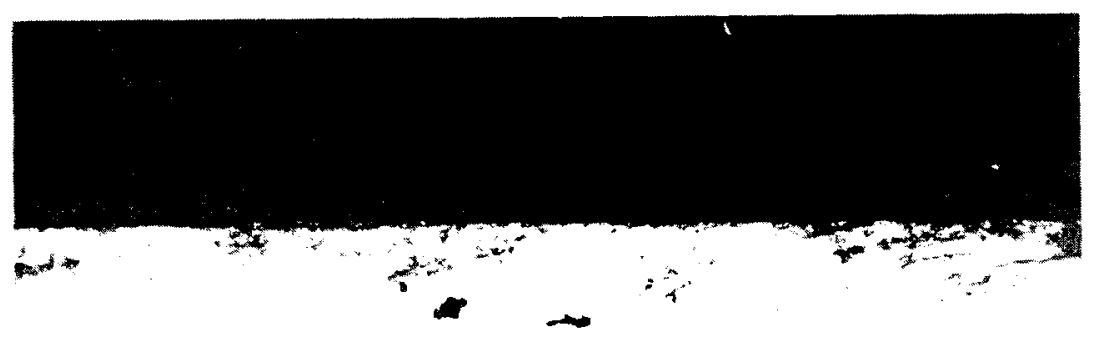

Neg. No.

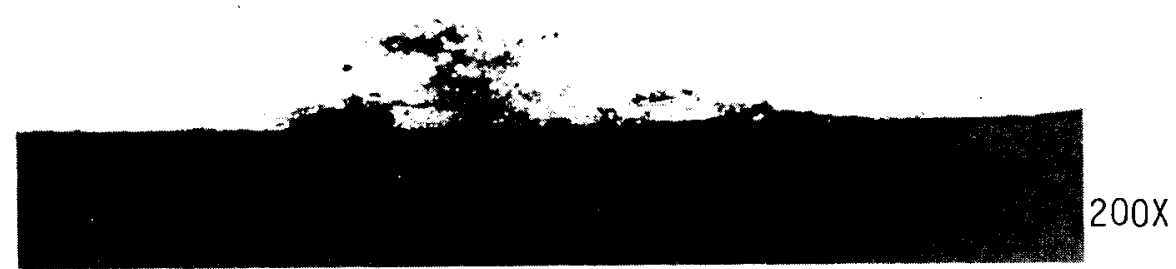

b. Operated at Ambient Temperature

FIGURE 32. Aluminum Alloy 6063 Fins Exposed for 2 Years to a Humid, Marine, Industrial Environment. a) Fin Held at Dry Cooling Tower Temperature. b) Control Fin Sample: at Ambient Temperature on Site but Away from Cooling System. Demonstrates Protection Provided by Operation at Dry Cooling Tower Temperatures. 


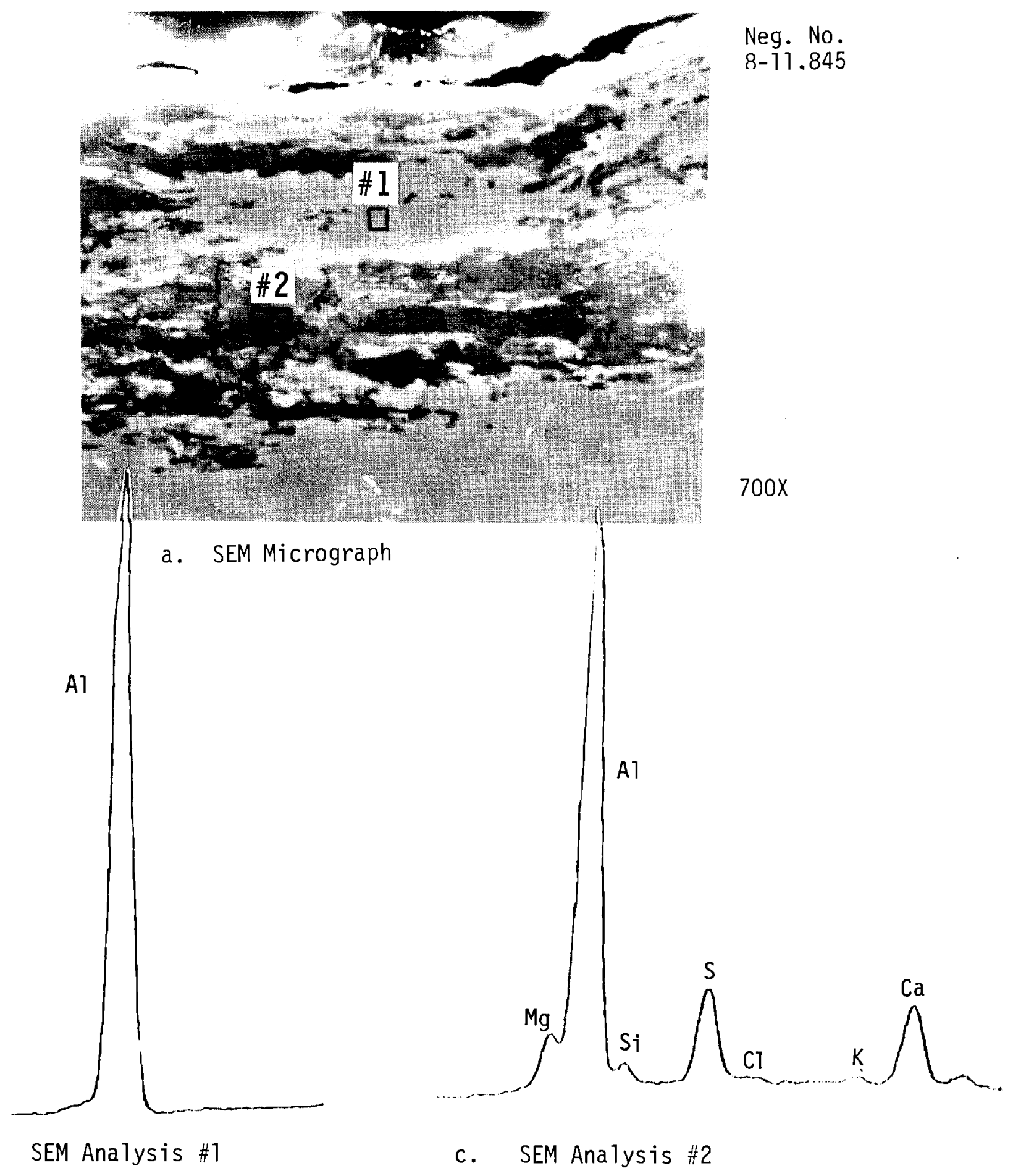

FIGURE 33. SEM Micrograph and Microprobe Analysis. a) Close-up of Region A in Figure 30. b) SEM Analysis \#1 Metallic Area of Aluminum Fin. c) SEM Analysis \#2 of Corrosion Product. 
corrosion occurred in crevices between the cooling coil fins and the spacer collars. This corrosion eventually resulted in perforation of the tubes, resulting in air leaks to the steam condensate system. The problem is attributed to high humidity, evaporative tower drift and atmospheric pollutants, the principal active contaminants being moisture and chlorides. Despite the tight mechanical joints between the fins and spacer collars, moisture containing chlorides penetrated the minute crevices and set up active corrosion cells behind the collars, causing pitting and finally perforation of the aluminum tube walls. Moisture kept these cells active, and the bulky corrosion products distorted the tubes locally. The corrosion eventually became widespread on the weatherside tubes (outer tubes of bundles), particularly in coolers that had been ciut of service for a period.

Attempting to solve the Rugeley corrosion problem, an epoxy coating was selected as the best method to protect the coolers from air-side corrosion. At the present time, all of the cooling coils at the Rugeley Station have been treated with the epoxy coating. However, air-side corrosion of the cooling coils is still continuing; the more recent problems are attributed to a difference in coil design which introduced a collar which prevented adequate coverage by the epoxy coating, leaving a thinly-coated local area which remained vulnerable to air-side corrosion. A method has been developed for sealing the leaks at a very low cost; the procedure does not involve dismantling or down time. (1)

Figure 34 shows a section of the Rugeley dry cooling tower. Figure 35 shows the spacing collar described above.

The scope of this investigation of aluminum as a dry cooling tower material is summarized in Table 4. 


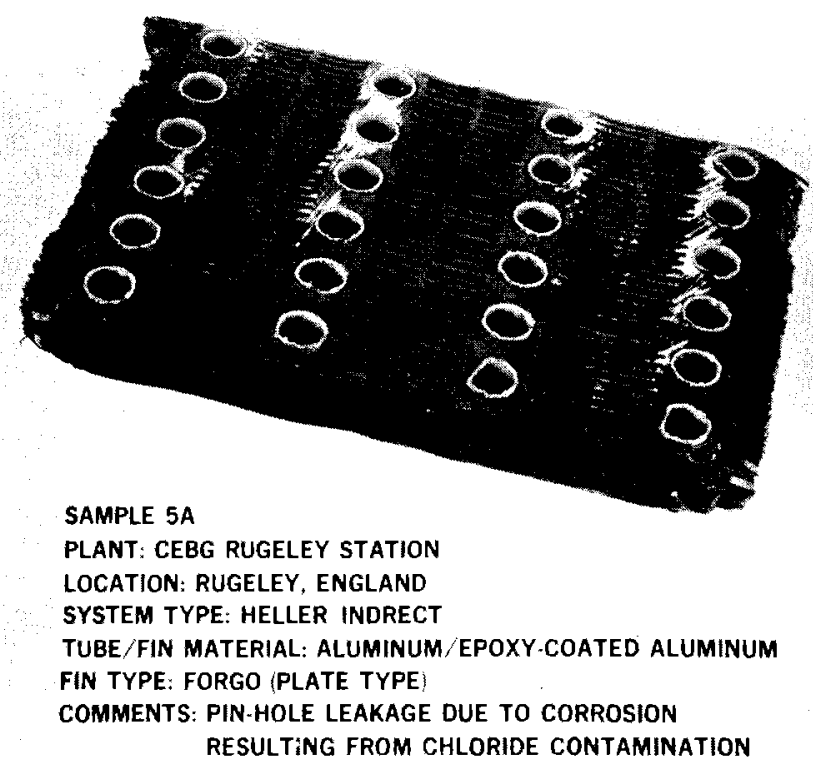

Neg. No. 754693-11

$0.36 x$

FIGURE 34. Section of Cooler from Rugeley, England, Removed for Examination. Unit is Epoxy-Coated.

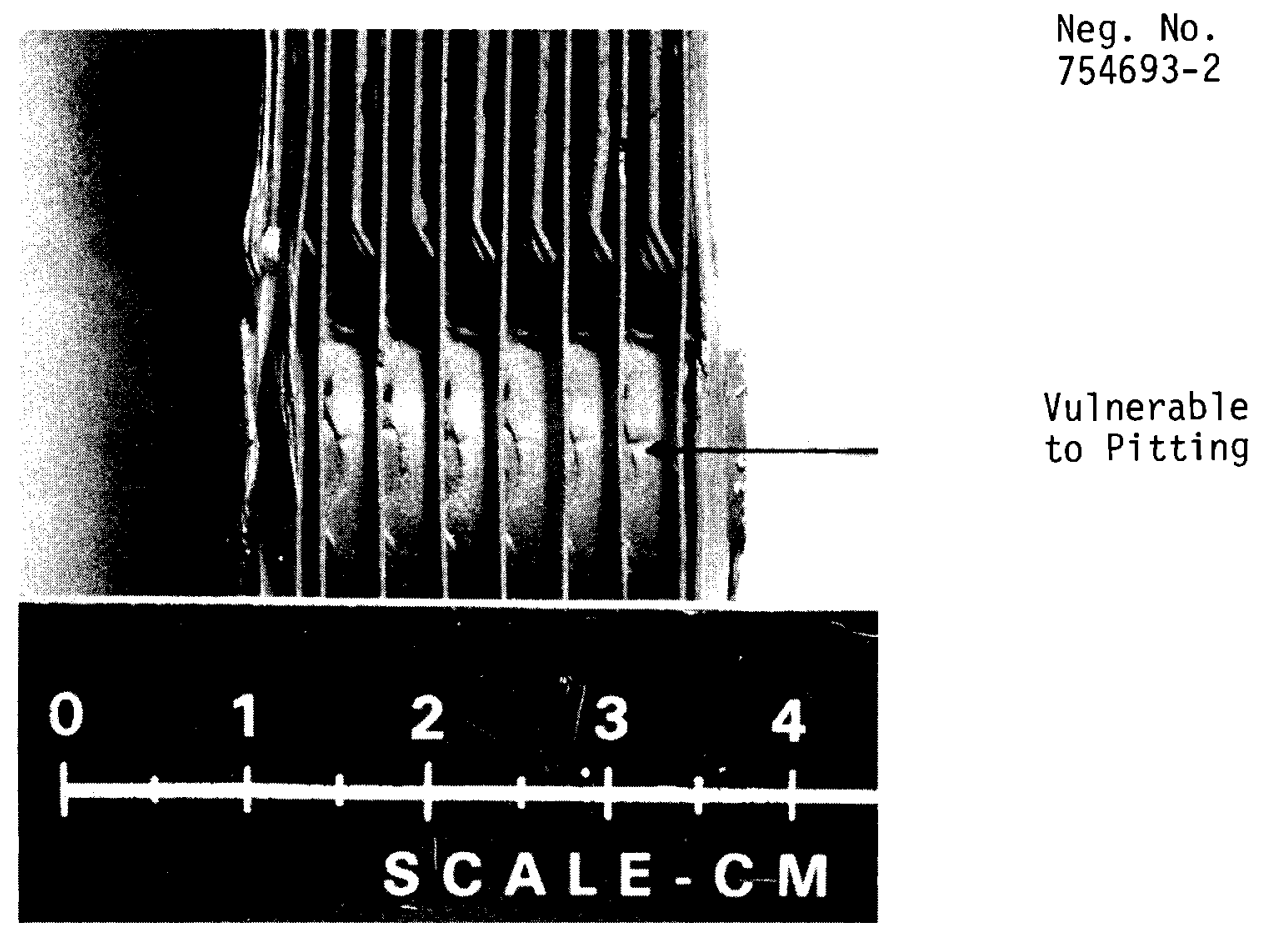

FIGURE 35. Close-up of Crevice Locations where Pinhole Leaks were Reported to Have Initiated. 
TABLE 4. Scope of Dry Cooling Tower Materials Investigation (a)

\begin{tabular}{|c|c|c|c|c|c|c|}
\hline \multirow[b]{2}{*}{ Environment } & \multicolumn{2}{|c|}{ Rural } & \multicolumn{2}{|c|}{ Industrial } & \multicolumn{2}{|c|}{ Marine } \\
\hline & Dry & Wet & Dry & Wet & Moist & Wet \\
\hline Location & $\begin{array}{l}\text { Washington } \\
\text { Columbia } \\
\text { Basin }\end{array}$ & $\begin{array}{l}\text { Mississipi } \\
\text { near Guif } \\
\text { Coast }\end{array}$ & $\begin{array}{l}\text { Texas } \\
\text { West-Central }\end{array}$ & $\begin{array}{l}\text { Ibbenbüren, } \\
\text { Germany }\end{array}$ & $\begin{array}{l}\text { Southern } \\
\text { California } \\
\text { Coast }\end{array}$ & $\begin{array}{l}\text { Louisiana } \\
\text { Gulf Coast }\end{array}$ \\
\hline $\begin{array}{l}\text { Extent of } \\
\text { Corrosion }\end{array}$ & Mild & Mild & Mild & Moderate & Moderate & Severe \\
\hline Alloy & (c) & $\begin{array}{l}\text { Probably } \\
1100 \mathrm{AT}\end{array}$ & (c) & (c) & $1100 \mathrm{AT}$ & $1100 \mathrm{~A} 1$ \\
\hline $\begin{array}{l}\text { Type of } \\
\text { Corrosion }\end{array}$ & $\begin{array}{l}\text { Shallow } \\
\text { Pitting }\end{array}$ & Intergranular & $\begin{array}{l}\text { Shallow } \\
\text { Pitting }\end{array}$ & Transgranula & (d) & Intergranuiar \\
\hline $\begin{array}{l}\text { Other } \\
\text { Factors } \\
\text { Involved }\end{array}$ & -- & -- & -- & Coal Dust & -- & Sulfur \\
\hline
\end{tabular}

\footnotetext{
(a) Specimens were obtained from operating dry-cooled equipment at each location for aluminum

(b) fin metallurgical evaluation of corrosion.

(c) Unknown.

(d) Sub-surface corrosion occurred; not clear whether attack is intergranular or transgranular.
} 


\subsection{LABORATORY EXPERIMENTS UNDER SIMULATED DRY-COOLED AND AMBIENT CONDITIONS}

The morphology and relative amounts of corrosion caused by contaminants actually encountered in industrial use were studied under laboratory conditions. This was an effort to evaluate the relative effects of several selected contaminants in a controlled environment. Corrosion tests were conducted at both ambient and elevated temperatures.

Contaminants were tested singly and in pairs.

\subsection{EXPERIMENTAL}

\subsubsection{Materials}

A series of specimen coupons, $3 / 4^{\prime \prime}$ square and $1 / 16^{\prime \prime}$ thick, were cut from a sheet of Alcoa 1100-H14 series aluminum. Alloy composition is given as follows.

\begin{tabular}{|c|c|c|c|}
\hline \multicolumn{4}{|c|}{$\begin{array}{l}\text { Wt Percent, Composition } \\
\text { of Al Alloy } 1100-\mathrm{H} 14\end{array}$} \\
\hline$(\mathrm{Si}+\mathrm{Fe})$ & $\mathrm{Mn}$ & $\mathrm{Mg}$ & $\mathrm{Zn}$ \\
\hline 1.0 & 0.0 & 0.0 & 0. \\
\hline
\end{tabular}

\subsubsection{Environment}

Nine of the coupons were held at a temperature above the dewpoint $\left(58^{\circ} \mathrm{C}\right.$ to $\left.68^{\circ} \mathrm{C}\right)$. Five specimens were held at room temperature $\left(\sim 20^{\circ} \mathrm{C}\right)$, and the remaining five specimens were cycled between room temperature and operating temperature. All specimens were in covered petri dishes under a hood, which provided flowing laboratory air. The petri dish lids were raised sufficiently to allow a gap for air circulation. Maximum, mean and minimum average relative humidities for the duration of the experiment (June 1976 to August 1977) are tabulated below for Richland, Washington, where the laboratory experiment was conducted: 


\section{Maximum Mean $\quad$ Minimum}

Average of Monthly Relative Humidities

93

52

18

(June 1976 to July 1977)

The Richland area is classified as desert, with average rainfalls of 6-8 in. per year. However, sprinkler irrigation and proximity to the Columbia River have some influence on the local humidity.

Ibbenbüren (Germany) coal (dusted from a specimen from an actual dry cooling tower section), sulfur, and $\mathrm{NaCl}$; were the principal industrial contaminants selected for the laboratory test. These contaminants were discussed in an earlier section of this report (Section 3.0). About half of the coupons were tested with only a single contaminant. The remaining specimens were contaminated with $\mathrm{NaCl}$ and either a coal or sulfur. Other contaminants that were used in only a few specimens and tested only at the elevated temperature were $\mathrm{NaSO}_{4}$ and Salinas, Utah coal. The contaminant(s) and environment(s) for each coupon are presented in Table 5 . The relative severity of the corrosion is shown by the numbers, with zero indicating absence of corrosion.

TABLE 5. Environments, Contaminants and Relative Severity of Observed Corrosion on Aluminum Alloy 1100

\begin{tabular}{|c|c|c|c|}
\hline Contaminant & $\begin{array}{c}\text { Elevated } \\
\text { Temperature } \\
\left(\sim 60^{\circ} \mathrm{C}\right) \\
\end{array}$ & $\begin{array}{l}\text { Room } \\
\text { Temp. } \\
\left(\sim 20^{\circ} \mathrm{C}\right) \\
\end{array}$ & $\begin{array}{c}\text { Cycled } \\
\left(20^{\circ} \rightarrow 60^{\circ} \mathrm{C}\right)\end{array}$ \\
\hline Blank (No Contaminant) & 0 & -- & -- \\
\hline Salinas, Utah Coal & 1 & -- & -- \\
\hline Ibbenbüren Coal & 2 & 2 & 3 \\
\hline $\mathrm{Na}_{2} \mathrm{SO}_{4}$ & 1 & -- & -- \\
\hline Sulfur & 0 & 0 & 0 \\
\hline $\mathrm{NaCl}$ & 3 & 7 & 2 \\
\hline $\mathrm{NaCl}$ and Salinas, Utah Coal & 0 & -- & -- \\
\hline $\mathrm{NaCl}$ and Ibbenbüren $\mathrm{Coa} 1$ & 4 & 1 & 9 \\
\hline $\mathrm{NaCl}$ and Sulfur & 1 & 10 & 5 \\
\hline
\end{tabular}




\subsubsection{Results of Specimen Examination}

After 405 days of testing, the specimens were mounted and examined metallographically. A relative evaluation of the amount of corrosion was made and is represented by the numbers given in Table 5. This is a visual subjective ranking of the corrosion observed on metallographic sections of the samples. The scale is from zero to 10 . Zeros indicated that no corrosion was observed on metallographic samples at magnifications up to 1000X, and 10 is assigned to the sample which evidenced the most corrosion.

Chloride ( $\mathrm{NaCl}$ ) appears to be the primary cause of corrosion and this is not unexpected. (10) Figures 36 and 37 show the effect of $\mathrm{NaCl}$ on aluminum in several environments. Elemental sulfur does not seem to be corrosive by itself (Fig. 38). The sulfur compound $\mathrm{Na}_{2} \mathrm{SO}_{4}$ caused only slight corrosion at the elevated temperature. Corrosion on specimens due to chloride when both $S$ and $\mathrm{Cl}^{-}$are present is illustrated in Figures 38 and 39 , suggesting the possibility of a synergistic interaction.

In the generic sense, "coal" seems to have a corrosive effect on aluminum (Fig. 40). The amount of corrosion is expected to depend upon the chemical composition of the coal as well as the environmental conditions (Fig. 41). Again, chloride appears to enhance the corrosive effect when mixed with coal contaminants, particularly when the environment is cycled between elevated and ambient temperatures, allowing periodic moisture adsorption, judging from the Ibbenbüren coal samples shown in Figures 42 and 43 SEM microanalysis of the most corroded specimen $(\mathrm{NaCl}+\mathrm{S})$, indicated that there is a definite chloride gradient from the contaminant and increasing toward the corrosion interface. Sulfur was also detected deep in the corrosion zone through the species is not known. This is in keeping with previous observations that sulfur may be synergistic with chloride. Microprobe analysis are presented in Figure 44. The corrosion appears to be transgranular (Fig. 45).

Comparison of analyses for Ibbenbüren coal and Salinas, Utah coal, (Table 6), demonstrates the potential importance of chloride. Ibbenbüren coal has the higher chloride content and also causes greater corrosion. 
Neg. No.

$4 \mathrm{M} 1052 \mathrm{~B}$

a. No Contaminants - Held at $60^{\circ} \mathrm{C}$

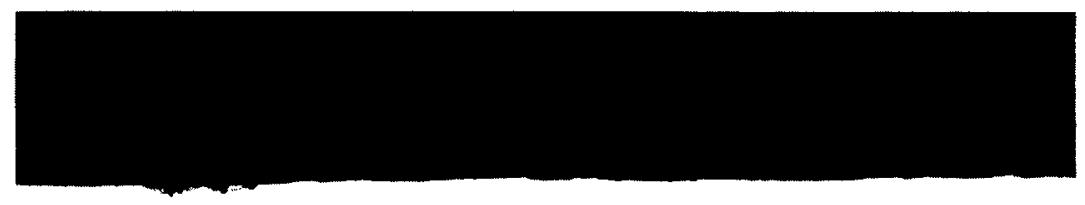

Neg. No.

$4 \mathrm{M} 1040 \mathrm{C}$

$250 x$

b. NaCl Contaminant - Held at $60^{\circ} \mathrm{C}$

FIGURE 36. Aluminum Alloy 1100 Coupons Held at $60^{\circ} \mathrm{C}$ with (a) No Contaminants and (b) $\mathrm{NaCl}$ Contaminant after 405 Days 


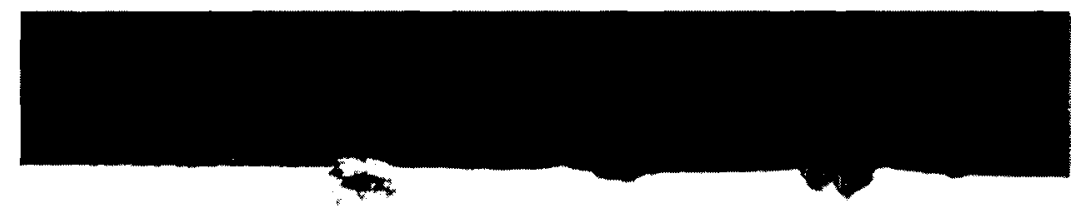

Neg. No.

4 M $1042 B$

$250 x$

a. Held at $\sim 20^{\circ} \mathrm{C}-\mathrm{NaCl}$ Contaminant

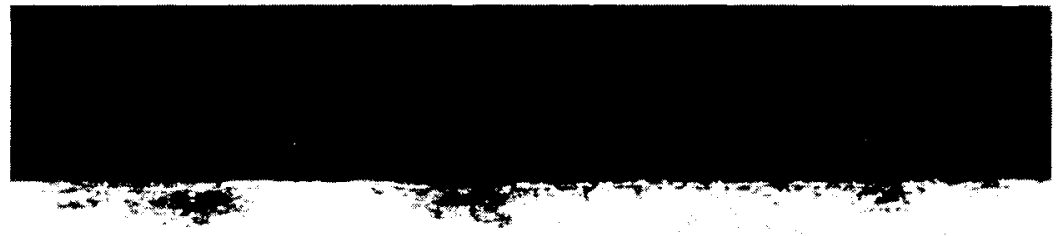

Neg. No.

$4 M 1041 \mathrm{C}$

$250 x$

b. Cycled between $\sim 20$ and $\sim 60^{\circ} \mathrm{C}-\mathrm{NaCl}$ Contaminant

FIGURE 37. Aluminum Alloy 1100 Coupons Contaminated with $\mathrm{NaCl}$ and (a) Held at $\sim 20^{\circ} \mathrm{C}$, (b) Periodically Cycled Between $\sim 20^{\circ} \mathrm{C}$ and $\sim 60^{\circ} \mathrm{C}$, after 405 Days. 
Neg. No.

$4 M 1034 B$

$250 x$

a. Sulfur Contaminant Only - Held at $60^{\circ} \mathrm{C}$

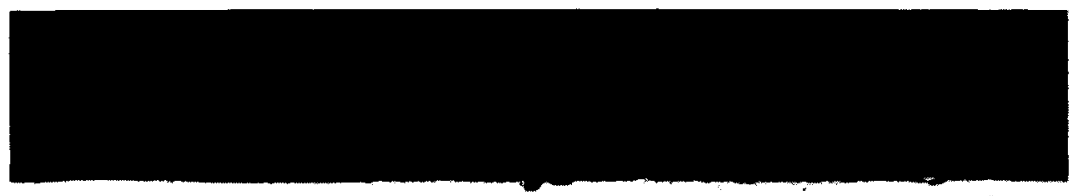

Neg. No.

$4 M 1044 C$

b. Sulfur and $\mathrm{NaCl}$ Contaminant - Held at $60^{\circ} \mathrm{C}$

FIGURE 38. Aluminum Alloy 1100 Coupons Held at $60^{\circ} \mathrm{C}$ and Contaminated with

(a) Elemental Sulfur Only, and (b) Sulfur and $\mathrm{NaCl}$ after 405 Days. 


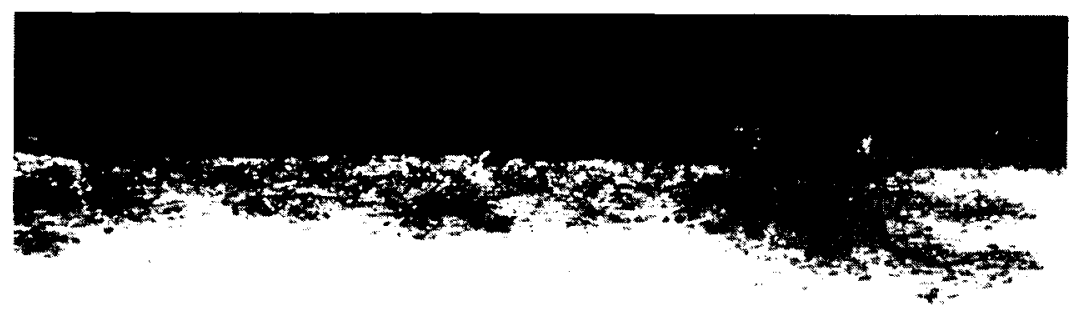

Neg. No.

$4 \mathrm{M} 1046 \mathrm{~B}$

$250 X$

a. Held at $\sim 20^{\circ} \mathrm{C}$ - Sulfur and $\mathrm{NaCl}$ Contaminant

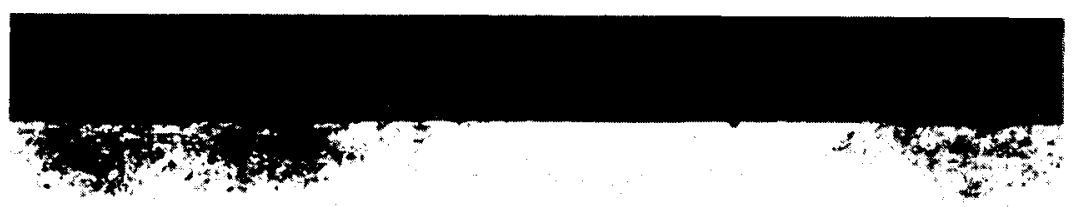

Neg. No. $4 M 1045 B$

b. Cycled between $\sim 20$ and $\sim 60^{\circ} \mathrm{C}$ - Sulfur and $\mathrm{NaCl}$ Contaminant

FIGURE 39. Aluminum Alloy 1100 Coupons Contaminated with Elemental Sulfur and $\mathrm{NaCl}$ and (a) Held at $\sim 20^{\circ} \mathrm{C}$, (b) Periodically Cycled between $\sim 20^{\circ} \mathrm{C}$ and $\sim 60^{\circ} \mathrm{C}$ after 405 Days. 


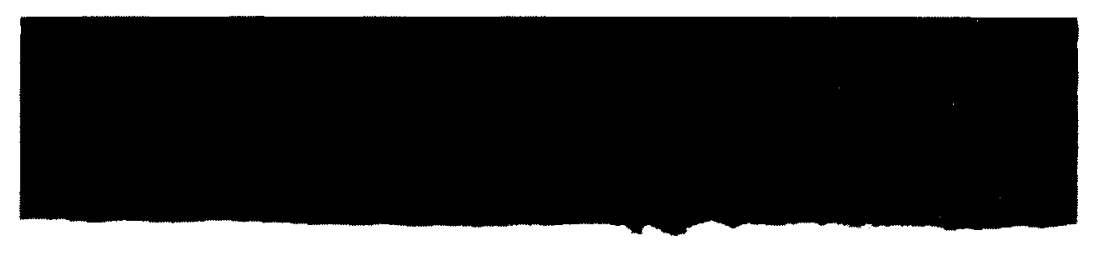

Neg. No.

$4 \mathrm{M} 1034 \mathrm{C}$

$500 x$

a. Low $\mathrm{Cl}^{-} \mathrm{Coa} 1$ - Held at $60^{\circ} \mathrm{C}$

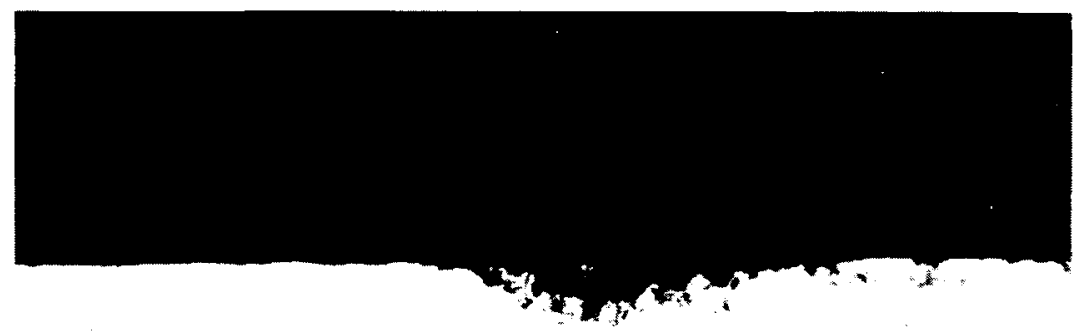

Neg. No.

4M 1037B

$500 x$

b. High $\mathrm{Cl}^{-} \mathrm{Coal}-\mathrm{Held}$ at $60^{\circ} \mathrm{C}$

FIGURE 40. Aluminum A1loy 1100 Coupons Held at $260^{\circ} \mathrm{C}$ and Contaminated with Coal from (a) Salinas, Utah (Low $\mathrm{Cl}^{-}$) (b) Ibbenbüren, Germany (High $\mathrm{Cl}^{-}$) after 405 Days. 


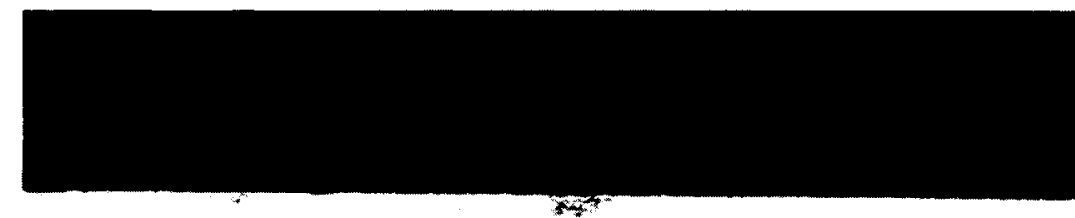

Neg. No.

$4 \mathrm{M} 1047 \mathrm{C}$

$250 x$

a. Held at $\sim 60^{\circ} \mathrm{C}-\mathrm{NaCl}$ and $\mathrm{Coal}$ Contaminant

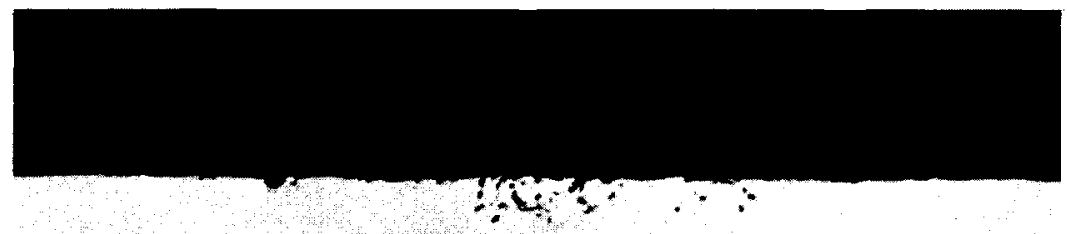

Neg. No. $4 \mathrm{M} 1049 \mathrm{C}$

$250 x$

b. Held at $\sim 20^{\circ} \mathrm{C}-\mathrm{NaCl}$ and $\mathrm{Coal}$ Contaminant

FIGURE 41. Aluminum Alloy 1100 Coupons Contaminated with $\mathrm{NaCl}$ and Coal from Ibbenbüren, Germany. a) Held at $\sim 60^{\circ} \mathrm{C}$. b) Held at $\sim 20^{\circ} \mathrm{C}$. 


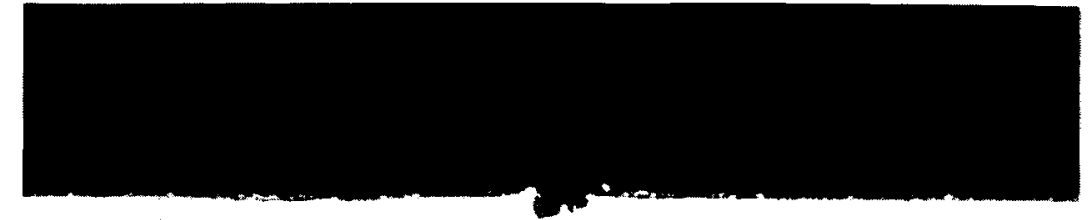

Neg. No.

4M 1039C

$500 x$

a. Held at $\sim 20^{\circ} \mathrm{C}-\mathrm{High} \mathrm{Cl}^{-} \mathrm{Coal}$ Contaminant

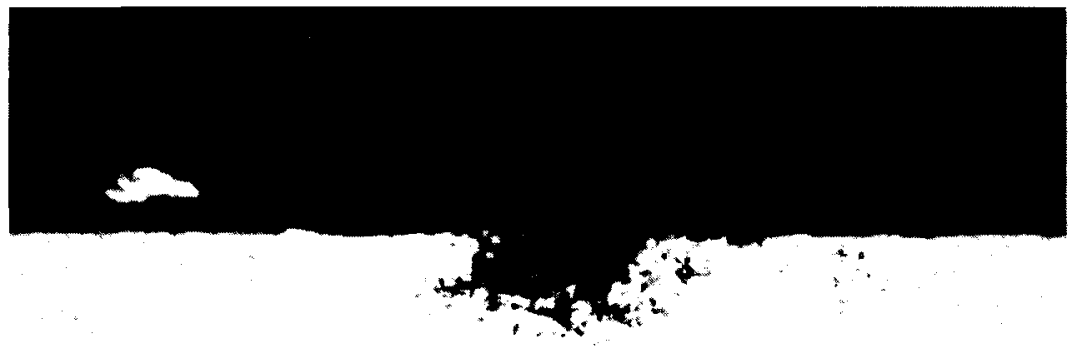

Neg. No.

4M 1038B

$500 x$

b. Periodically Cycled Between $\sim 20^{\circ} \mathrm{C}$ and $60^{\circ} \mathrm{C}-\mathrm{High} \mathrm{Cl}{ }^{-} \mathrm{Coal}$ Contaminant

FIGURE 42. Aluminum Alloy 1100 Coupons Contaminated with High Cl${ }^{-}$Coal from Germany and a) Held at $220^{\circ} \mathrm{C}$ for 405 Days, b) Periodically Cycled between $\sim 20^{\circ} \mathrm{C}$ and $60^{\circ} \mathrm{C}$ for 405 Days 


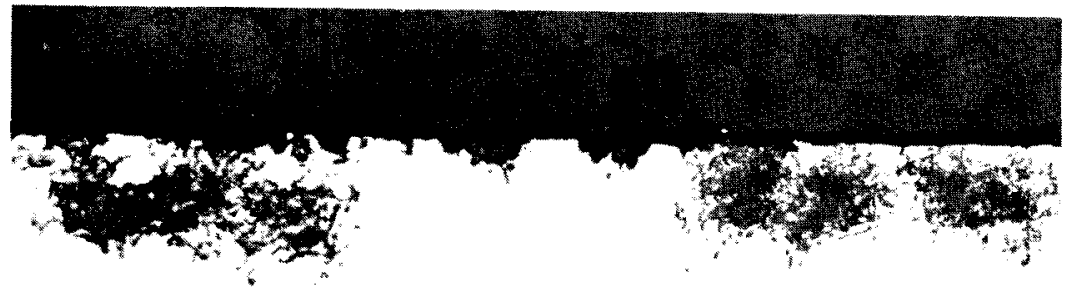

Neg. No.

$4 M 1048 B$

a. Unetched

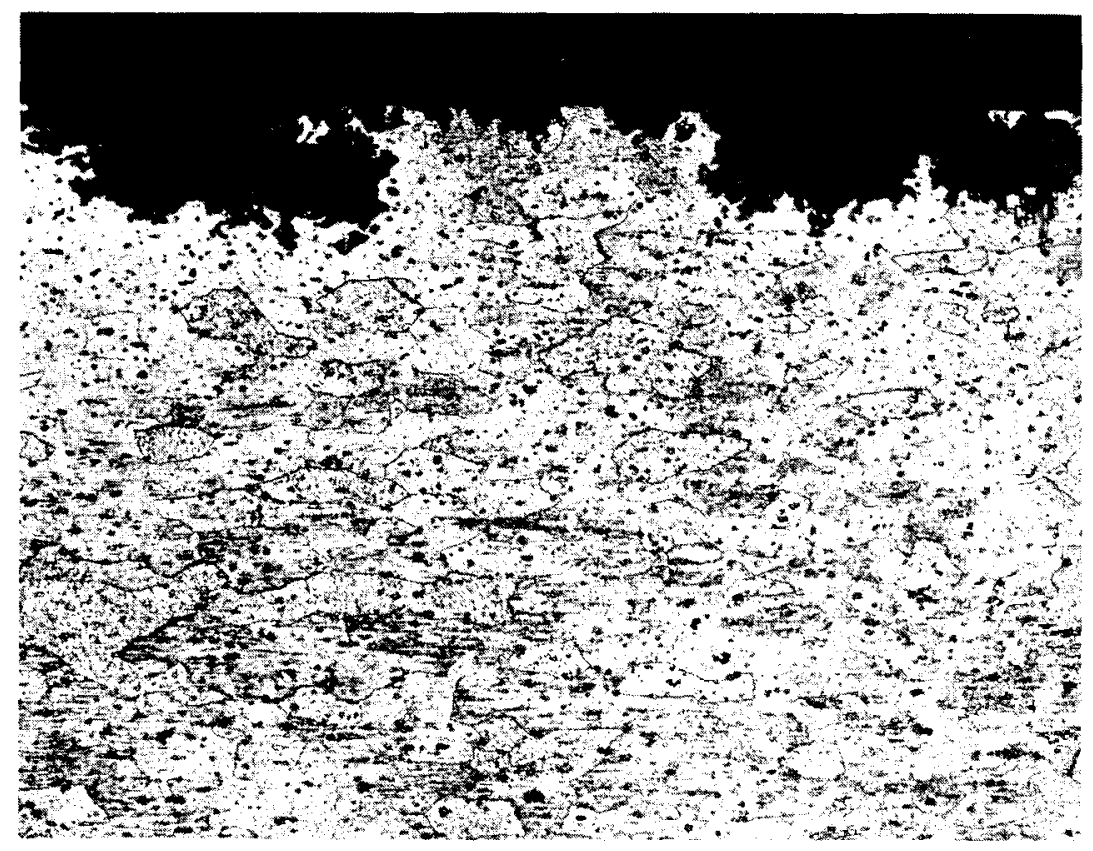

Neg. No. $4 \mathrm{M} 1048 \mathrm{C}$

Etchant:

Keller's Etch

Etch Time:

$10 \mathrm{sec}$ immersion

$250 x$

b. Etched

FIGURE 43. a) Unetched and b) Grain Boundary Etched View of an Aluminum Alloy 1100 Coupon Contaminated with $\mathrm{NaCl}$ and $\mathrm{Coal}$ from Ibbenbüren, Germany and Periodically Cycled Between $\sim 20^{\circ} \mathrm{C}$ and $\sim 60^{\circ} \mathrm{C}$ after 405 Days. 


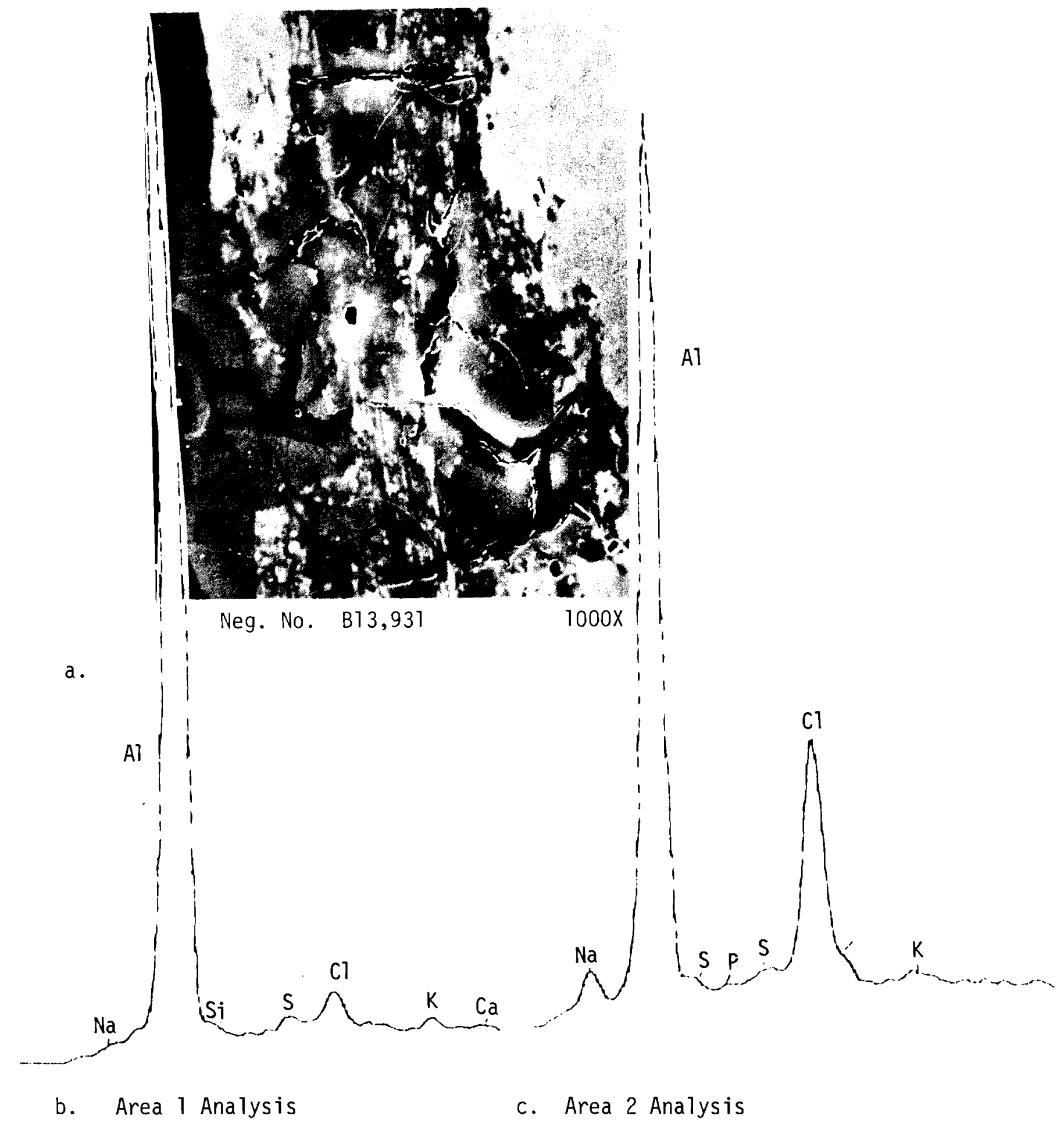

FIGURE 44. Aluminum Alloy 1100 Coupon Contaminated with $\mathrm{S}+\mathrm{NaCl}$ and Held at $\sim 20^{\circ} \mathrm{C}$. a) SEM Micrograph Showing where Analyses were Taken. b) Microprobe Analys is of Contaminant (Area 1). c) Microprobe Analysis of Corrosion Product (Area 2). 


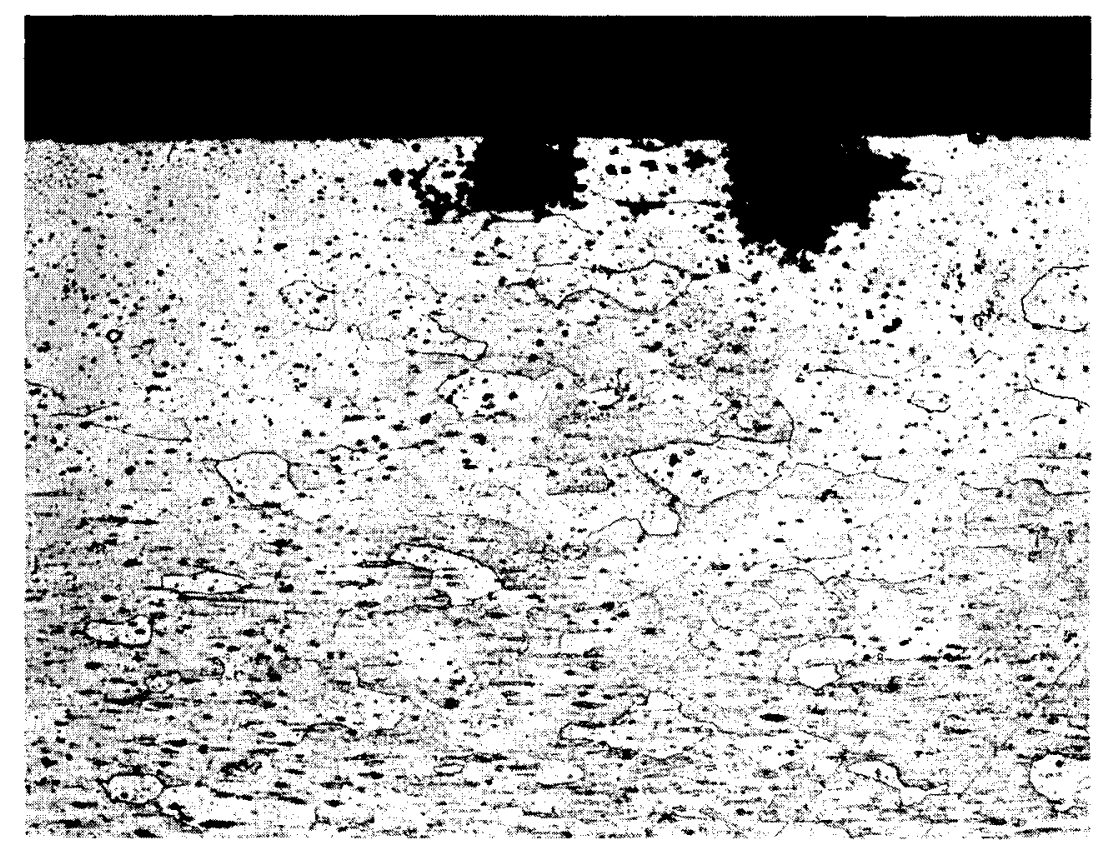

Neg. No.

4M 1048E

a. Grain

Boundary

Etch

(Keller's)

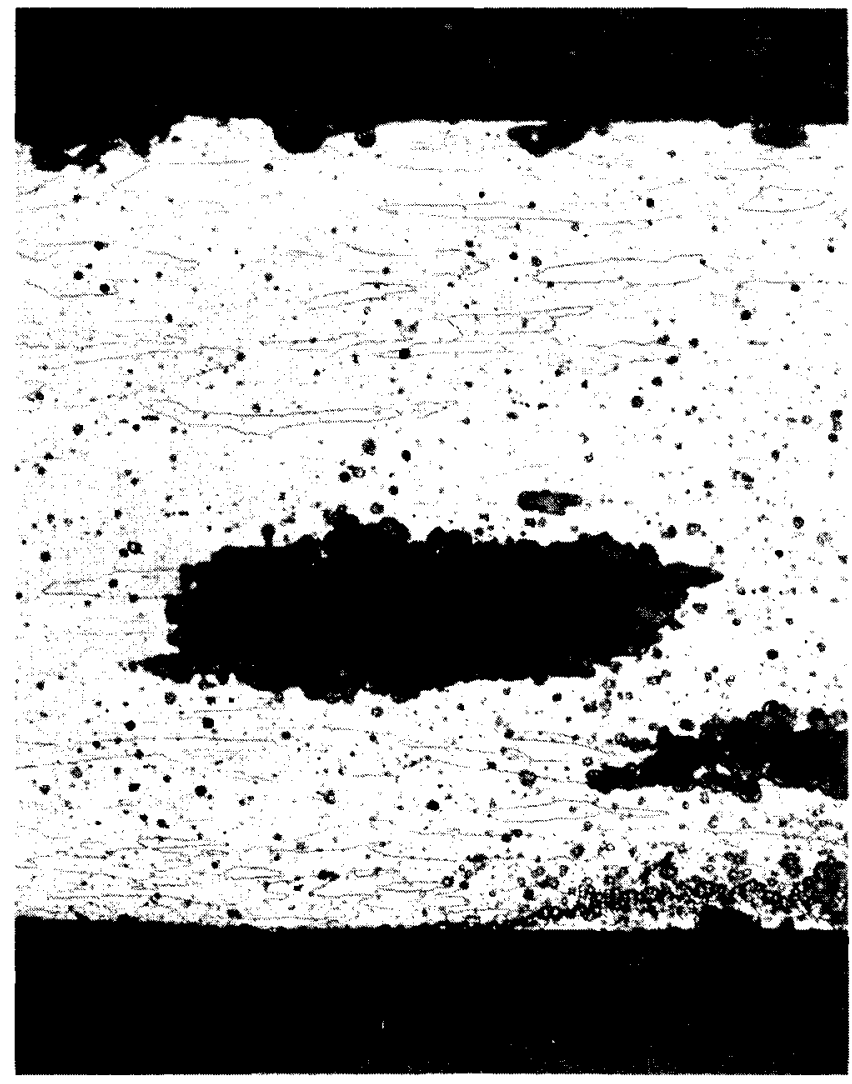

Neg. No.

4M 1167B

b. Grain

Boundary

Etch

(Keller's)

FIGURE 45. Comparison of Corrosion Observed on Aluminum. a) Laboratory Sample ( $\mathrm{NaCl}+$ Ibbenbürren Coal, 405 Days Periodic Cycling between $\sim 20^{\circ} \mathrm{C}$ and $\sim 60^{\circ} \mathrm{C}$ ) b) Fin Section from Ibbenbüren, Germany Dry Cooling Tower. Corrosion Appears to be Transgranular in both Cases. 
However, the relative amounts of other potentially corrosive species, such as sulfur compounds are not known. Figures 36-38 indicate the lesser importance of sulfur, unless it occurs in conjunction with chloride. Table 6 shows the sulfur analysis of the two coals.

TABLE 6. $\begin{aligned} & \text { Analysis of Salinas, Utah and } \\ & \text { Ibbenbüren, Germany, Coals }\end{aligned}$
$\begin{array}{lcc}\text { Salinas, Utah Coal } & \text { Ibbenbüren Coal } \\ \mathrm{S} & 0.8 \% & <2 \% \\ \mathrm{Cl}^{-} & 0.0028 \% & 0.15 \% \\ \mathrm{~F}^{-} & 0.00349 \% & 0.37 \%\end{array}$

\subsection{CONCLUSIONS-LABORATORY EXPERIMENT}

The laboratory experiment confirmed that aluminum fins exposed at dry cooling tower temperatures are far less prone to corrosion than identical materials exposed at ambient temperatures. Aluminum dry cooling tower materials are susceptible to corrosion in any environment which provides chlorides. The most obvious environment fitting this classification is the marine environment. But the Ibbenbüren coal analyses have shown that chlorides can also occur where coal dust is present. However, comparisons of two coals indicated large differences in chloride content.

The coal with the higher chloride content was also more corrosive to aluminum. Of major significance with regard to the aggressiveness of the corrosion is the amount of time that the system is off line. The corrosive effect of chloride is largely inhibited when moisture is not available. This would correspond to the system being on line and at a temperature above the dewpoint. Obviously, a constant source of moisture similar to that found in a marine environment (for example, wet cooling towers near the dry tower) would contribute to corrosion of the plant materials during periods when the plant is off line. 
The laboratory studies suggested that elemental sulfur is not aggressive to aluminum, but combined with chloride, it appeared to act synergistically to accelerate corrosion. However, further work would be required to confirm the synergism.

The laboratory studies suggested that for some contaminants (Table 5) cycling between ambient and operating conditions may enhance corrosion.

The results of the laboratory test suggests that useful insights to dry cooling tower materials performance can be generated by this approach. 


\section{REFERENCES}

1. J. G. DeSteese and K. Simhan, European Dry Cooling Tower Operating Experience. BNWL-1995, Battel Te, Pacific Northwest Laboratories, Richland, Washington, March 1976.

2. A. B. Johnson, Jr., D. R. Pratt and G. E. Zima, A Survey of Materials and Corrosion Performance in Dry Cooling Applications. BNWL-1958, Battelle, Pacific Northwest Laboratories, Richland, Washington, March 1976.

3. "Engineering and Economic Evaluation of Wet/Dry Cooling Towers for Water Conservation." United Engineers and Constructors, Inc., Philadelphia, Pennsylvania, July 1976.

4. Dry Cooling Tower Program: Results of Industrial Contacts Through August 1974. BNWL-1878, Batte11e, Pacific Northwest Laboratories, Richland, Washington, November 1974.

5. J. P. Rossie and E. A. Cecil, Research on Dry-Type Cooling Towers for Thermal Electric Generation. R. W. Beck and Associates, report prepared for the Federal Water Quality Administration, November 1970.

6. J. E. Hall and G. C. Blaze, Performance of Aluminum Alloys at Black Hilis Power and Light." NeiT Simpson Station, Wyodak, WY, ATcoa Rept. 5-XE-533, Alcoa, PA, June 1973.

7. W. H. Caruthers, Corrosion Performance of Aluminum Finned Dry Cooling Tower Coils at Neil Simpson Station, Wyodak, Wyoming. Reynolds Metals Company, Richmond, Virginia, 1973.

8. W. K. Boyd and F. W. Fink, Corrosion of Metals in the Atmosphere. MCIC-74-23, Battelle Memorial Institute, Columbus, Ohio, 1974.

9. D. R. Clements and R. A. Bonewitz, Performance of Finned Aluminum Heat Exchangers in Power Plant Dry Cooling Tower Service. ALCOA, ATcoa, PA, 1972.

10. Z. A. Foroulis and M. J. Thubrikar, "On the Kinetics of the Breakdown of Passivity of Pre-anodized Aluminum by Chloride Ions." J. Electrochem. Soc., 122, 1296, 1975.

11. R. Ellinger, "Symposium on Atmospheric Corrosion of Non-Ferrous Metals." American Society for Testing Materials, Baltimore, MD, 1956, p. 33, 55-64.

12. M. J. Lavigne, "Intergranular Corrosion of High-Purity ATuminum." Met. Prog., 64, 1953. 
13. 0. P. Arora and M. Metzger, "Corrosion of Some Tilt and Twist Boundaries in Aluminum Bicrystals." Trans. Met. Soc. AIME, 236, 1205, 1966.

14. E. Herzog, "Rapid Tests for Intercrystalline Corrosion." Met. Prog., $58,355,1950$.

15. F. H. Haynie and S. I. Ketcham, "Electrochemical Behavior of Aluminum Alloys Susceptible to Intergranular Corrosion." Corrosion, Houston, TX, 4075, 1963.

16. H. H. Uhlig, Corrosion and Corrosion Control. 2nd Edition, John Wiley and Sons, Inc., New York, 1971.

17. K. R. Van Horn (ed.), Aluminum. I, Amer. Soc. of Metals, 1967.

18. F. L. LaQue and H. R. Copson, Corrosion Resistance of Metals and Alloys. 2nd Edition, Reinhold Pub. Corp., New York, 1963.

19. G. Schikorr, "The Sulfur Dioxide-Repellent Action of Aluminum Exposed to the Influence of the Atmosphere." Aluminum, 43(2):108-110, February 1967.

20. H. H. Uhlig, Corrosion Handbook. John Wiley and Sons, Inc., New York, 1948. 


\section{ACKNOWLEDGMENT}

The authors are grateful to D. R. Pratt for comments on the draft, to R. Beauchamp for metallographic examinations, to J. L. Daniel for Scanning Electron Microscopy. Several industrial organizations, who choose not to be identified for propriety reasons, have provided specimens and have also cooperated in providing operating information on dry-cooled equipment. This work was conducted under the Dry-Cooling Tower Program, conducted at Battelle's Pacific Northwest Laboratories, sponsored by the Energy Research and Development Administration, Division of Nuclear Research and Applications, under Contract EY-76-C-06-1830. 


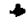

\author{
.
}


PNL -2392

UC -12

\section{DISTRIBUTION}

No. of

Copies

\section{$\underline{\text { OFFSITE }}$}

A. A. Churm

DOE Chicago Patent Group

9800 South Cass Avenue

Argonne, IL 60439

United States Department of Energy Office of Assistant General

Counsel for Patents

Washington, DC 20545

307 DOE Technical Information

\section{Center}

4 W. F. Savage

Advanced Concepts

Evaluation Branch

DOE Division of Nuclear

Research and Application

Washington, DC 20545

G. W. Cunningham

Acting Deputy Director

for Technology

DOE Division of Nuclear Research

and Application

Washington, DC 20545

A. J. Pressesky

Acting Assistant Director

for Technology

DOE Division of Nuclear

Research and Application

Washington, DC 20545

G. A. Newby

Acting Director

DOW Division of Nuclear Research and Application

Washington, DC 20545
No. of

Copies
D. H. Groelsema

Chief, Engineering and

Components Development Branch

DOE Division of Nuclear

Research and Application

Washington, DC 20545

T. Beresovski

Chief, Advanced Concepts

Evaluation Branch

DOE Division of Nuclear

Research and Application

Washington, DC 20545

B. R. Dickey

A11ied Chemical Company

550 2nd Street

Idaho Falls, ID 83401

J. S. Joyce

Allis-Chalmers Power Sys tems, Inc.

1135 South 70th Street

West Allis, WI 53214

E. T. Wanderer

Aluminum Company of America

Alcoa Technical Center

Alcoa Center, PA 15069

H. J. Janzon

American Electric Power

2 Broadway

New York, NY 10004

T. Woods

Arizona Public Service Company

$2121 \mathrm{~W}$. Cheryl Drive

Phoenix, AZ 85021

J. P. Budliger

Battel le-Geneva

7 Routh De Drizi

1227 Geneva, SWITZERLAND 
No. of

Copies

K. Simhan

Battelle Institute eV. 6000 Frankfurt/Main 90

Postfach 900160

GERMANY

G. C. Cree 1

Baltimore Gas \& Electric Co.

Gas \& Electric Bldg.

Baltimore, MD 21203

E. Schinner

Baltimore Aircoil Co., Inc.

P.0. Box 7322

Baltimore, MD 21227

G. E. Collins

Research Cottrell

Hamon Cooling Tower Division

P.0. Box 750

Bound Brook, NJ 08805

W. Kals

Niagara Blower

405 Lexington Avenue

New York, NY 10017

M. W. Peterson

Babcock \& Wilcox

Fossil Power Division

20 South Van Buren

Barberton, OH 44203

W. Kee?

Texas Electric Service Co.

115 W. Seventh St.

Fort Worth, TX 76102

R. J. Meyer

Louisiana Power \& Light Co.

142 Delaronde St.

New Orleans, LA 70174

S. Ragone

Virginia Electric \& Power Co.

$700 \mathrm{E}$. Franklin St.

Richmond, VA 23261
No. of

Copies

H. T. Wilson

Tampa Electric Co.

P.0. Box 111

Tampa, FL 33601

P. Leung

Bechte 1 Corporation

P.0. Box 60860

Termina] Annex

Los Angeles, CA 90060

G. R. Retti

Bechtel Corporation

P.0. Box 3965

San Francisco, CA 94719

J.P. Rossie

R. W. Beck \& Associates

400 Prodential Plaza

Denver, C0 80202

W. J. Westre

Black Hills Power and Light Co.

P.0. Box 1400

Rapid City, SD 57701

J. Sell

Carolina Power and Light Co. 336 Fayettesville St.

Raleigh, NC 27602

J. Morse

Catalytic Construction Corp.

P.0. Box 11402

Charlotte, NC 28029

R. H. Holyoak

Commonwealth Edison

One First Plaza

P.0. Box 767

Chicago, IL 60690

C. L. Newman

Consolidated Edison Company of New York, Inc.

4 Irving Place

New York, NY 10003 
F. K. Moore

Cornell University

I thaca, NY 14850

R. C. Haberski

Curtiss Wright Corp.

One Passaic St.

Wood Ridge, NJ 07075

S. K. Blackley

Duke Power Co.

P.0. Box 2178

Charlotte, NC 28201

J. K. Swindt

Ecodyne Cooling Products Co.

P. 0. Box 1267

Santa Rosa, CA 95403

J. Maulbetsch

Electric Power Research Institute

3412 Hillview Ave.

P.0. Box 10412

Palo Alto, CA 94304

L. Geller

Empire State Electric Energy Research Corp.

1250 Broadway

New York, NY 10001

F. H. Rainwater

Environmental Protection Agency

Pacific Northwest Water Laboratory

200 S.W. 35th St.

Corvallis, OR 97330

A. M. Rubin

Franklin Institute

Twentieth \& Parkway

Philadelphia, PA 19103

B. Davis

GEA Airexchangers, Inc.

46 Worthington Dr.

Maryland Heights, MD 63043
D. A. Nelson

General Atomics

P.0. Box 81608

San Diego, CA 92138

E. H. Miller

General Electric Co.

Large Steam Turbine Division

300 Nott St.

Schenectady, NY 12301

J. F. Sebald

Gilbert Associates, Inc.

525 Lancaster Ave.

Reading, PA 19603

J. E. Taboric

Heat Transfer Research, Inc.

1000 S. Fremont Ave.

Alhambra, CA 91802

E. C. Smith

Hudson Products

6855 Horwin Dr.

Houston, TX 77036

M. W. Larinoff

Hudson Products

6855 Horwin Dr.

Houston, TX 77036

C. Rocco

Italimpianti - Societa

Italiana Impianti p.a.

Piazza, Piccapietra 9

18121 Genoa, ITALY

J. L. Mulloy

Los Angeles Department of Water and Power

111 N. Hope St.

Los Angeles, CA 90012

R. Landon

Marley Company

5800 Fox Ridge Dr.

Mission, KS 66202 
No. of Copies

L. R. Glicksman

Massachusetts Institute of Technology

77 Massachusetts Ave. Cambridge, MA 02139

W. G. Hoydysn

New York University University Heights

New York, NY 10453

R. H. Meyer

Northeast Utilities

P.). Box 270

Hartford, CT 06101

F. F. Mautz

Pacific Gas \& Electric

77 Beale St.

San Francisco, CA 94106

P. G. Humphries

Pacific Power \& Light Co.

Public Service Bldg.

Portland, OR 97204

T. Rozenman

PFR Engineering Systems

1417 S. Georgia St.

Los Angeles, CA 90015

A. C. Smith

Power Generation Cooling Systems

4714 52nd St. S.

Seattle, WA 98118

R. F. Walker

Public Service of Colorado

5900 E. 39th Ave.

Denver, CO 80207

E. D. Kist

Public Service of New Mexico

Corporate Planning Dept.

Albuquerque, NM 87103
No. of

Copies

B. Caruthers

Reynolds Aluminum Co.

Reynolds Metallurgical

Research Laboratory

Richmond, VA 23261

Prof. Ing. Carlo Roma

Piazza delle Muse 8

Rome, ITALY

R. G. Lacy

San Diego Gas \& Electric

101 Ash St.

San Diego, CA 92107

R. L. Skone

Seattle City Light

1015 Third Ave.

Seattle, WA 98104

J. Rasband

Southern Califorria Edison

2244 Walnut Grove Ave.

Rosemead, CA 91770

P. Sporn

Consultant Engineer

74 Trinity P1., Suite 511

New York, NY 10006

J. Y. Parce

Stearns and Rogers

$700 \mathrm{~S}$. Ash St.

Denver, CO 80222

D. H. Guild

Stone \& Webster Engineering Corporation 225 Franklin St. Boston, MA 02107

G. J. Kidd Union Carbide Corporation ORGDP - K-25

P.0. Box D

Oak Ridge, TN 37803 
G. A. Engelson

United Engineers and Constructors

IVB Bldg.

1700 Market St.

Philadelphia, PA 19105

J. F. Kennedy

University of Iowa

Hydraulic Research Institute

Iowa City, IA 52240

L. P. Davis

Dept. of Mechanical

Engineering

Oregon State University

Corvallis, OR 97330

C. E. Wicks

Dept. of Chemical Engineering Oregon State University

Corvallis, OR 97330

J. H. Hutchinson

Utah Power \& Light

1407 W. N. Temple

Salt Lake City, UT 84103

G. H. Soule

West Associates

Sierra Pacific Power Co.

100 E. Moana Lane

Reno, NV 89510

K. A. 0leson

Westinghouse Electric Corp.

Steam Turbines Division

Lester Branch

P.0. Box 9175

Philadelphia, PA 19113

G. J. Silvestri

Westinghouse Electric Corp.

Steam Turbines Division

Lester Branch

P.0. Box 9175

Philadelphia, PA 19113
B. W. Walters

Tennessee Gas Transmission

P.0. Box 2511

Houston, TX 77001

L. C. Unger

Transcontinental Gas Pipeline Corporation

P.0. Box 1396

Houston, TX 77001

J. W. Cronenberg

El Paso Natural Gas

600 Building of the Southwest

Midland, TX 79701

W. Berry

Battelle Columbus Laboratories 505 King Avenue

Columbus, $\mathrm{OH} 43201$

E. H. Phelps

U.S. Steel Research Laboratory

125 Jamison Lane

Monroeville, PA 15146

J. S. Slotnik

Ecodyne Corporation

MRM Division

607 First Street S.W.

Massillion, $\mathrm{OH} 44646$

E. G. Bauer

Wean United, Inc.

1400 Grace Avenue, N.E.

P.0. Box 1769 Station A

Canton, $\mathrm{OH} 44705$

G. Rogers

Scovill Manufacturing Company

99 Mill Street

Waterbury, CT 06720

D. Brodine

Ford Motor Company

P.0. Box 177

Lima, OH 45802 
H. G. Gillit

Northwest Pipeline Corp.

275 East $200 \mathrm{~s}$.

Salt Lake City, UT 84111

T. Summerson

Kaiser Aluminum

P.0. Box 870

Pleasanton, CA 94566

K. Lehner

Wisconsin Electric Power Co.

231 W. Michigan Ave.

Milwaukee, WI 53203

R. S. French

Copper Development

Association, Inc.

405 Lexington Ave.

New York, NY 10017

M. D. Orton

Pacific Gas \& Electric Co.

77 Beale St.

Room 2844

San Francisco, CA 94106

G. H. Horne

Standard 0il Company

P.0. Box 3069

San Francisco, CA 94119

R. E. Moore

Texas Eastern Transmission Corp.

P.0. Box 1612

Shreveport, LA 71130

D. Tonini

American Hot Dip

Galvinizers Assoc., Inc.

1000 Vermont Ave., N.W.

Washington, DC 20005

J. S. Nordin

Betz Environmental Engineering

One Plymouth Meeting Mal1

Plymouth Meeting, PA 19462
D. K. Traverse

Southern California Gas Co.

Box 3249 Terminal Annex

Los Angeles, CA 90051

B. Hadley

Michigan Wisconsin Pipeline Co.

1 Woodward Avenue

Detroit, MI 48226

R. I. Lindberg

Reynolds Metals Company

Fourth and Canal Streets

Richmond, VA 23219

ONSITE

DOE Richland Operations Office

Program Division

H. E. Ransom

B. J. Melton

Westinghouse Hanford Company

Hanford Engineering

Development Laboratory

J. Fletcher

\section{Battelle-Northwest}

R. T. Allemann

T. W. Ambrose

S. Begej (3)

J. W. Currie

D. E. Deonigi

J. G. Desteese

R. L. Dillon

D. W. Dragnich

D. W. Faletti

J. W. Finnigan

C. H. Henager

A. B. Johnson, Jr. (20)

W. S. Kelly

R. S. Kemper

C. J. Knoll 
No. of

Copies

Battelle-Northwest - (cont'd)

W. V. Loscutoff

R. P. Marsha 11

R. P. May (3)

D. E. Olesen

Y. Onishi

L. T. Pedersen

H. C. Riches

J. B. Schuette

G. C. Smith

J. S. Stoakes

A. M. Sutey

D. S. Trent

M. Vagins

R. A. Walter

R. L. Watts

R. D. Widrig

R. K. Woodruff

G. E. Zima

File - B. M. Johnson (30)

Technical Information (5)

Technical Publications 
. 